DOE/EIA-0608(95)

Distribution Category UC-950

\title{
Voluntary Reporting of Greenhouse Gases 1995
}

\author{
July 1996
}

Energy Information Administration

Office of Integrated Analysis and Forecasting

U.S. Department of Energy

Washington, DC 20585



This report was prepared by the Energy Information Administration, the independent statistical and analytical agency within the Department of Energy. The information contained herein should not be construed as advocating or reflecting any policy position of the Department of Energy or of any other organization. 


\section{HOW TO OBTAIN EIA PRODUCTS AND SERVICES}

For further information on any of the following services, or for answers to energy information questions, please contact EIA's National Energy Information Center:

$\begin{array}{ll}\text { National Energy Information Center (NEIC) } & \text { (202) 586-8800 } \\ \text { Energy Information Administration } & \text { (202) 586-0727 (fax) } \\ \text { Forrestal Building, Room 1F-048 } & \text { TTY: (202) 586-1181 } \\ \text { Washington, DC 20585 } & \text { E-mail: infoctr@eia.doe.gov }\end{array}$

\section{Electronic Products and Services}

EIA's Internet Site Services offer nearly all EIA publications. Users can view and download selected pages or entire reports, search for information, download EIA data and analysis applications, and find out about new EIA information products and services.

\section{World Wide Web: http://www.eia.doe.gov \\ Gopher: gopher://gopher.eia.doe.gov \\ FTP: ftp://ftp.eia.doe.gov}

EIA also offers a listserve service for EIA press releases and other short documents. Sign up on the EIA World Wide Web site.

EIA's CD-ROM, Energy InfoDisc, contains most EIA publications, several databases, and an energy forecasting model. The Energy InfoDisc, produced quarterly, is available for a fee from STAT-USA, Department of Commerce, 1-800-STAT-USA.

The Comprehensive Oil and Gas Information Source (COGIS), a bulletin board service, contains data files from most of EIA's oil- and gas-related reports. It is available for a fee from STAT-USA, on 1-800-STAT-USA.

EIA's Electronic Publishing System (EPUB) bulletin board contains data files, directories, and forecasts from most EIA reports. It can be accessed free of charge by dialing (202) 586-2557.

Many of EIA's data files and modeling programs are available for sale on diskette, tape, or cartridge, through either the National Technical Information Service or the Office of Scientific and Technical Information, Department of Energy. Contact NEIC for information on specific products, sources, and media, and ordering instructions.

\section{Printed Publications}

EIA directories are available free of charge from NEIC. Recent periodicals and one-time reports are available from the Government Printing Office. Older reports are available from the National Technical Information Service:

Superintendent of Documents U.S. Government Printing Office P.O. Box 371954 Pittsburgh, PA 15250-7954 (202) 512-1800; (202)-512-2250 (fax)
National Technical Information Service U.S. Department of Commerce Springfield, VA 22161

5285 Port Royal Road (703) 487-4650; (703) 321-8547 (fax)

Released for Printing July 5, 1996 


\section{DISCLAIMER}

Portions of this document may be illegible in electronic image products. Images are produced from the best available original document. 


\section{Contacts}

This report, Voluntary Reporting of Greenhouse Gases 1995, was prepared under the general direction of Mary J. Hutzler, Director of the Office of Integrated Analysis and Forecasting, Energy Information Administration. General questions concerning the content of this report may be referred to Arthur T. Andersen, Director of the Energy Demand and Integration Division (202/5861441).
Specific technical information concerning the content of the report may be obtained from Arthur Rypinski (202/586-8425, e-mail arypins@eia.doe.gov). This report was prepared by Arthur Rypinski, Dick Richards, Bryan de Boinville, Michael Mondshine, Alan Laskin, Chris Minnucci, Gabriela Martin, Kenneth Pruitt, and Laura Gehlin.

\section{How to Report}

Persons or members of organizations wishing to report reductions in emissions of greenhouse gases under the auspices of the Voluntary Reporting Program can contact the Energy Information Administration at:

Voluntary Reporting of Greenhouse Gases

Energy Information Administration

U.S. Department of Energy

Forrestal Building

EI-81, Room 2F-081

1000 Independence Avenue, SW

Washington, DC 20585

Telephone: $1-800-803-5182$

e-mail: infoghg@eia.doe.gov

The EIA has both a long form (EIA-1605) and a short form (EIA-1605EZ) available, as well as an electronic version of the form. All are available upon request. 


\section{Preface}

Title XVI, Section 1605(b) of the Energy Policy Act of 1992 (enacted October 24, 1992) provides, in part:

(B) Voluntary Reporting.-

(1) ISSUANCE OF GUIDELINES.-. . . [T]he Secretary [of Energy] shall ... issue guidelines for the voluntary collection and reporting of information on ... greenhouse gases ....

(2) REPORTING PROCEDURES.-The Administrator of the Energy Information Administration shall develop forms for voluntary reporting under the guidelines established under paragraph (1), and shall make such forms available to entities wishing to report such information ....

(4) ESTABLISHMENT OF DATA BASE.... IT]he Secretary through the Administrator of the Energy Information Administration shall establish a data base comprised of information voluntarily reported under this subsection....

This report documents actions taken by the Energy Information Administration (EIA) to fulfill the requirement under the law to develop forms, make them available to the public, and establish a data base of reported information. It caps an effort spanning more than 2 years, during which the EIA's Voluntary Reporting Team provided advice to the Department of Energy's Office of Policy in developing reporting guidelines; developed reporting forms consistent with those guidelines; pre-tested the forms with potential reporters; solicited public review and comment; cleared the forms with the Office of Management and Budget (OMB) under the Paperwork Reduction Act; distributed paper and electronic forms, received reports, provided technical assistance to reporters, reviewed the data on the incoming reports, and worked with reporters to correct data problems; developed a computer database to contain the incoming data; and finally, prepared this report on the results of the first reporting cycle.

The EIA would like to extend its thanks to the 108 firms, households, and government agencies that participated in the first reporting cycle, and particularly to those organizations that agreed to give their time to participate in the pre-testing of the data collection forms and software. The development of the Voluntary Reporting Program has also required the efforts of many talented individuals over the past 2 years, and the EIA would like to acknowledge their efforts. Some of the people who have made significant contributions to the program include:

- Forms Development: Arthur Andersen, Louise Guey-Lee, Alan Laskin, Dick Richards, Tom Devlin, William Townsend, Chris Minucci, Michael Mondshine, Neal Miller, Lisa Gustavsen, Cary Gaunt, Carol Winston, Christine Lewicki, Al Pearson, Kenneth Pruitt, Tim Brown.

- Technical Assistance and Review of Voluntary Reports: The forms development team, plus Gabriela Martin, Laura Gehlin, Theresa Sebik.

- Electronic Form: Bryan de Boinville and Anne Eberhardt.

- Database Development: John Molineaux and William LaPerch.

- OMB Clearance: Herbert Miller and John Gross.

- Report Preparation: Charles L. Smith. 


\section{Contents}

Executive Summary $\ldots \ldots \ldots \ldots \ldots \ldots \ldots \ldots \ldots \ldots \ldots \ldots \ldots \ldots \ldots \ldots \ldots \ldots \ldots \ldots \ldots \ldots \ldots \ldots$

1. The Voluntary Reporting Program: An Overview $\ldots \ldots \ldots \ldots \ldots \ldots \ldots \ldots \ldots \ldots \ldots \ldots \ldots \ldots$

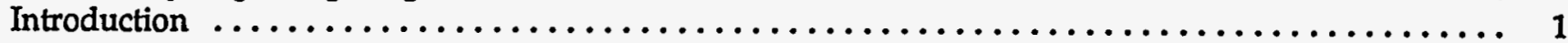

Plan of the Report $\ldots \ldots \ldots \ldots \ldots \ldots \ldots \ldots \ldots \ldots \ldots \ldots \ldots \ldots \ldots \ldots \ldots \ldots \ldots \ldots \ldots \ldots$

Development of the Voluntary Reporting Program $\ldots \ldots \ldots \ldots \ldots \ldots \ldots \ldots \ldots \ldots \ldots \ldots \ldots \ldots$



Who Reported $\ldots \ldots \ldots \ldots \ldots \ldots \ldots \ldots \ldots \ldots \ldots \ldots \ldots \ldots \ldots \ldots \ldots \ldots \ldots \ldots \ldots \ldots \ldots$

2. Entity-Level Reports $\ldots \ldots \ldots \ldots \ldots \ldots \ldots \ldots \ldots \ldots \ldots \ldots \ldots \ldots \ldots \ldots \ldots \ldots \ldots \ldots \ldots \ldots . \ldots$

National Greenhouse Gas Emissions Trends $\ldots \ldots \ldots \ldots \ldots \ldots \ldots \ldots \ldots \ldots \ldots \ldots \ldots \ldots$



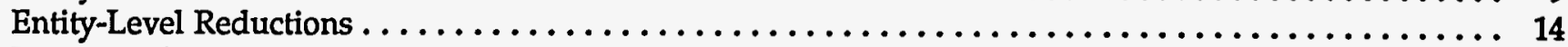

Future Reduction Commitments Made Under Schedule IV $\ldots \ldots \ldots \ldots \ldots \ldots \ldots \ldots \ldots \ldots \ldots \ldots 16$

3. Summary and Case Studies of Reported Projects $\ldots \ldots \ldots \ldots \ldots \ldots \ldots \ldots \ldots \ldots \ldots \ldots \ldots \ldots \ldots$

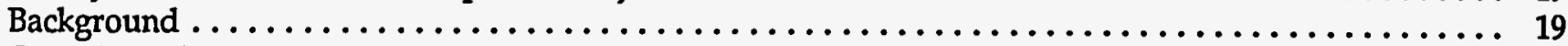

Overview of Projects Reported $\ldots \ldots \ldots \ldots \ldots \ldots \ldots \ldots \ldots \ldots \ldots \ldots \ldots \ldots \ldots \ldots \ldots \ldots \ldots \ldots 19$

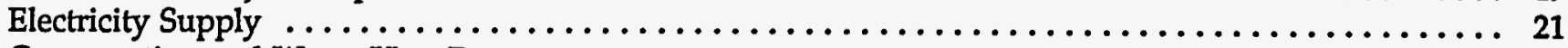

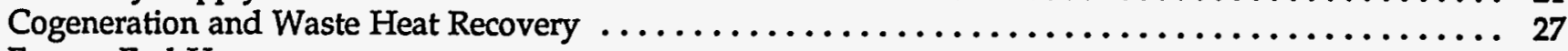



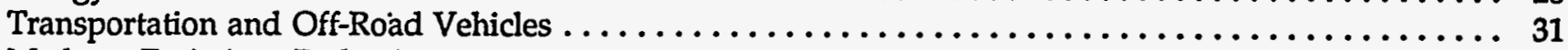

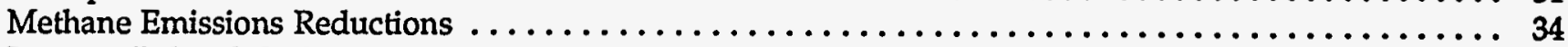

Forestry-Related Carbon Sequestration and Carbon Dioxide Emissions Reductions . . . . . . . . . 38

Halogenated Substances $\ldots \ldots \ldots \ldots \ldots \ldots \ldots \ldots \ldots \ldots \ldots \ldots \ldots \ldots \ldots \ldots \ldots \ldots \ldots \ldots \ldots, 41$

Other Emissions Reduction Projects $\ldots \ldots \ldots \ldots \ldots \ldots \ldots \ldots \ldots \ldots \ldots \ldots \ldots \ldots \ldots \ldots \ldots \ldots \ldots .43$

4. Emissions Accounting Issues $\ldots \ldots \ldots \ldots \ldots \ldots \ldots \ldots \ldots \ldots \ldots \ldots \ldots \ldots \ldots \ldots \ldots \ldots \ldots \ldots$

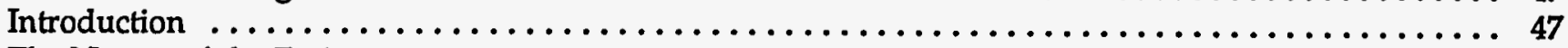



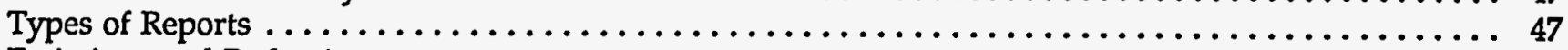

Emissions and Reductions $\ldots \ldots \ldots \ldots \ldots \ldots \ldots \ldots \ldots \ldots \ldots \ldots \ldots \ldots \ldots \ldots \ldots \ldots \ldots \ldots$

Direct and Indirect Emissions and Reductions $\ldots \ldots \ldots \ldots \ldots \ldots \ldots \ldots \ldots \ldots \ldots \ldots \ldots \ldots \ldots \ldots 48$

Reporting Fuel Cycle Effects $\ldots \ldots \ldots \ldots \ldots \ldots \ldots \ldots \ldots \ldots \ldots \ldots \ldots \ldots \ldots \ldots \ldots \ldots \ldots \ldots \ldots . \ldots$

The Nature of the Reference Case $\ldots \ldots \ldots \ldots \ldots \ldots \ldots \ldots \ldots \ldots \ldots \ldots \ldots \ldots \ldots \ldots \ldots \ldots \ldots$





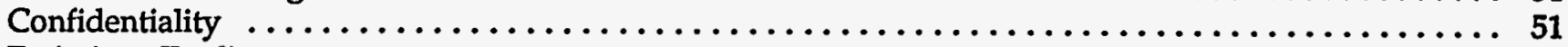





Appendixes

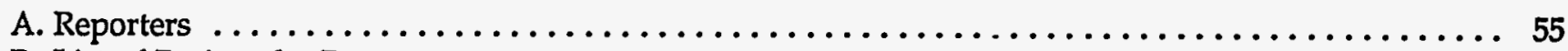

B. List of Projects by Reporter $\ldots \ldots \ldots \ldots \ldots \ldots \ldots \ldots \ldots \ldots \ldots \ldots \ldots \ldots \ldots \ldots \ldots \ldots \ldots$




1. Reports Received, by Standard Industrial Classification and Report Type $\ldots \ldots \ldots \ldots \ldots \ldots \ldots \ldots \quad 7$

2. Distribution of Reports Received by Category of Information Reported $\ldots \ldots \ldots \ldots \ldots \ldots \ldots \ldots \ldots 7$

3. Estimated U.S. Emissions of Greenhouse Gases, $1987-1994 \ldots \ldots \ldots \ldots \ldots \ldots \ldots \ldots \ldots \ldots \ldots \ldots .9$

4. Total Carbon Dioxide Emissions Reported to the Voluntary Reporting Program by Type of Activity,

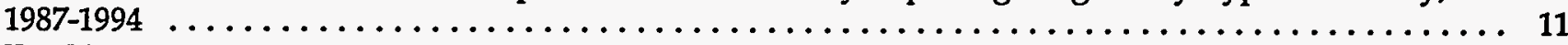

5. Total Emissions of Other Gases Reported to the Voluntary Reporting Program, 1987-1994 . . . . . . . 12

6. Total Emissions of Other Gases Reported to the Voluntary Reporting Program, 1987-1994,

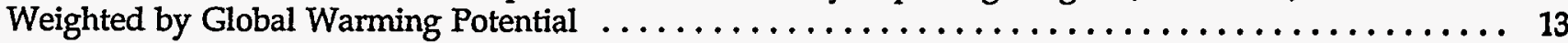

7. Summary of Detroit Edison's Entity-Level Emissions Report . . . . . . . . . . . . . . . 15

8. Changes in 1994 Emissions of Halogenated Substances and Minor Gases Reported by General Motors

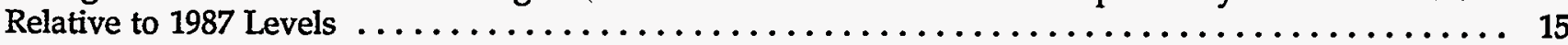

9. Reported Entity-Level Emissions Reductions by Type of Reference Case, 1991-1994 . . . . . . . . . . . 17

10. Summary of Reported Emissions Reduction and Carbon Sequestration Projects by Project Type . . . . . . 19

11. Summary of Project-Level Emissions Reductions and Carbon Sequestration ............... 20

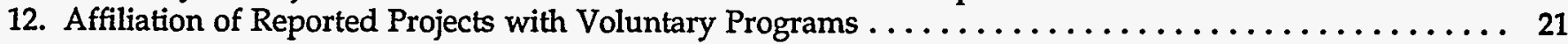

13. Electricity Savings Reported for End-Use Projects, $1991-1994 \ldots \ldots \ldots \ldots \ldots \ldots \ldots \ldots \ldots \ldots \ldots \ldots . \ldots . \ldots \ldots$

14. Carbon Dioxide Reductions Reported for End-Use Projects, $1991-1994 \ldots \ldots \ldots \ldots \ldots \ldots \ldots \ldots$. . . . 31

15. Carbon Dioxide Emissions Reductions by Transportation Project Type . . . . . . . . . . . . 32

16. Methane Emissions Reduction Projects by Project Type and Size $\ldots \ldots \ldots \ldots \ldots \ldots \ldots \ldots \ldots \ldots \ldots . \ldots \ldots$

17. Reported Carbon Sequestration Projects by Project Type $\ldots \ldots \ldots \ldots \ldots \ldots \ldots \ldots \ldots \ldots \ldots \ldots \ldots . \ldots \ldots$

18. Reported Carbon Sequestration and Emissions Reductions, $1991-1994 \ldots \ldots \ldots \ldots \ldots \ldots \ldots \ldots \ldots \ldots 41$

19. Location of Forestry Projects $\ldots \ldots \ldots \ldots \ldots \ldots \ldots \ldots \ldots \ldots \ldots \ldots \ldots \ldots \ldots \ldots \ldots \ldots \ldots \ldots$

20. Carbon Dioxide Reductions Reported for Other Emissions Reduction Projects, 1991-1994 . . . . . . . . . 43

21. Carbon Dioxiide Emissions Reductions Reported for Coal Ash Utilization Projects, 1991-1994 . . . . . . . 44

\section{Figures}

1. Entity-Level Emissions of Greenhouse Gases by Emission Type, 1987-1994 . . . . . . . . . . . . . 14

2. Average 1994 Emissions Reduction or Carbon Sequestration Achieved per Project by Project Type .... 21



4. Electricity Emissions Reduction Projects by Project Size $\ldots \ldots \ldots \ldots \ldots \ldots \ldots \ldots \ldots \ldots \ldots \ldots \ldots 23$

5. Electricity Emissions Reduction Projects by Project Type $\ldots \ldots \ldots \ldots \ldots \ldots \ldots \ldots \ldots \ldots \ldots \ldots \ldots 23$

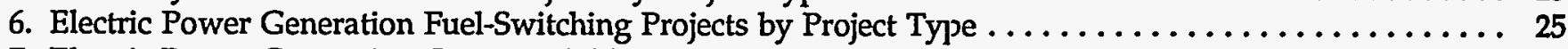

7. Electric Power Generation Capacity Addition Projects by Energy Source $\ldots \ldots \ldots \ldots \ldots \ldots \ldots \ldots \ldots . \ldots 25$

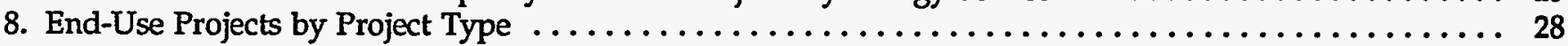

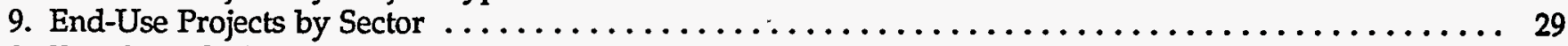

10. Trends in Carbon Dioxide Emissions from the U.S. Transportation Sector, 1987-1994 . . . . . . . . . . 31

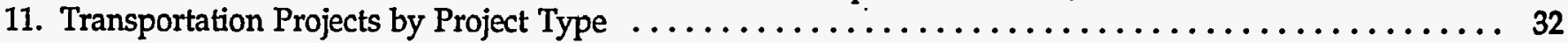

12. Transportation Emissions Reduction Projects by Project Type and Size $\ldots \ldots \ldots \ldots \ldots \ldots \ldots \ldots \ldots$

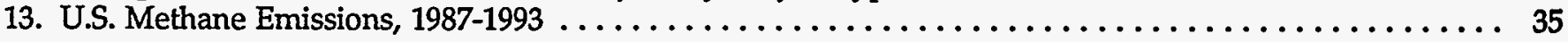

14. Reported Methane Emissions Reductions by Project Type $\ldots \ldots \ldots \ldots \ldots \ldots \ldots \ldots \ldots \ldots \ldots \ldots$ 


\section{Executive Summary}

The Voluntary Reporting Program for greenhouse gases is part of an attempt by the U.S. Government to develop innovative, low-cost, and nonregulatory approaches to limit emissions of greenhouse gases. It is one element in an array of such programs introduced in recent years as part of the effort being made by the United States to comply with its national commitment to stabilize emissions of greenhouse gases under the Framework Convention on Climate Change.

The Voluntary Reporting Program, developed pursuant to Section 1605(b) of the Energy Policy Act of 1992, permits corporations, government agencies, households, and voluntary organizations to report to the Energy Information Administration (EIA) on actions taken that have reduced or avoided emissions of greenhouse gases.

The first reporting year for the Voluntary Reporting Program was 1995. A total of 108 reports were received, encompassing some 645 individual emissions reduction projects, and 40 reports of "entity-level" greenhouse gas emissions, attributable to an entire organization (Table ES1). Emissions of greenhouse gases reported to the program account for about 23 percent of U.S. national carbon dioxide emissions. Reports received cover annual emissions from 1987 to 1994 and annual reductions claimed between 1991 and 1994.
Reporting in 1995 was dominated by electric utilities, which accounted for 96 of the 108 reporters. The following are highlights of the 1995 reporting cycle:

- Firms reporting "entity-wide" emissions claimed total reductions of 63 million metric tons of carbon dioxide and about 80,000 metric tons of methane and other gases in 1994. Differences in definitions and scope of reporting mean that reported total reductions should be viewed as rough approximations of effects rather than a precise statistical compilation of overall program consequences.

- Reporting utilities included 12 of the 15 largest emitting electric utilities in the United States. Aggregate emissions reported by electric utilities totaled some 773 million metric tons in 1994, or about 15 percent of national carbon dioxide emissions and 43 percent of national electric utility carbon dioxide emissions.

- The 12 nonutilities that reported included 3 manufacturing firms (General Motors, IBM, and Johnson \& Johnson), 2 aluminum companies (Noranda and Alcan), a coal company (Peabody Holding), an independent power producer (Northwest Fuel Development), a landfill methane developer (Zahren Alternative Energy), 2 forestry groups (Trees for the Future and the Oregon State University), and 2 households.

Table ES1. Summary of Reports Recelved

(Number of Reporters)

\begin{tabular}{|c|c|c|c|c|c|}
\hline \multirow[b]{2}{*}{ Type of Report } & \multicolumn{2}{|c|}{ Type of Form Filed } & \multicolumn{2}{|c|}{ Type of Reporter } & \multirow[b]{2}{*}{ Total } \\
\hline & $\begin{array}{l}\text { Short } \\
\text { Form }\end{array}$ & $\begin{array}{l}\text { Long } \\
\text { Form }\end{array}$ & $\begin{array}{l}\text { Electric } \\
\text { Utilities }\end{array}$ & Others & \\
\hline Total Reports Received .................... & 35 & 73 & 96 & 12 & 108 \\
\hline Reported on Reduction Projects . . . . . . . . . . . . . . . . & 35 & 64 & 87 & 12 & 99 \\
\hline Reported on Entity-Wide Emissions or Reductions & NA & 40 & 37 & 3 & 40 \\
\hline Reported Future Commitments To Reduce Emissions .... & NA & 42 & 42 & 0 & 42 \\
\hline
\end{tabular}

NA $=$ not applicable.

Source: Energy Information Administration, Forms EIA-1605 and EIA-1605EZ, "Voluntary Reporting of Greenhouse Gases" (1995 reporting cycle). 
- Among the entity-level reporters, 12 firms claimed that they were able to reduce their emissions below the level of a base year, usually 1990 or an average of 1987-1990. The largest reductions were claimed by Niagara Mohawk Power Corporation, Northeast Utilities, Central Hudson Gas \& Electric, and the New England Electric System.

- Of the 645 separate reduction projects identified by reporters, 438 involved electricity end use and electricity supply activities (Figure ES1). The reduction projects collectively reported emissions reductions of about 66 million metric tons of carbon dioxide. These reduction reports, however, overlap extensively with the aggregate emissions reports. They also have varied and often inconsistent definitions of scope and coverage.

- Many of the less frequently reported types of projects contained information of considerable interest. General Motors reported on its success in phasing out chlorofluorocarbon use in motor vehicles that were built in the early 1990s. Two aluminum smelters reported on reducing emissions of perfluorocarbons, which are rare but highly potent greenhouse gases. Northwest Fuel Development reported on a project to capture methane leaking from an abandoned mine for commercial use. Forestry organizations reported on domestic and foreign reforestation projects and foreign rain forest protection activities.

- Forty-two firms, all electric utilities, submitted commitments to reduce emissions in the future, encompassing more than $\mathbf{2 0 0}$ separate actions.
Figure ES1. Voluntary Reporting of Emisslons Reduction Projects by Project Type

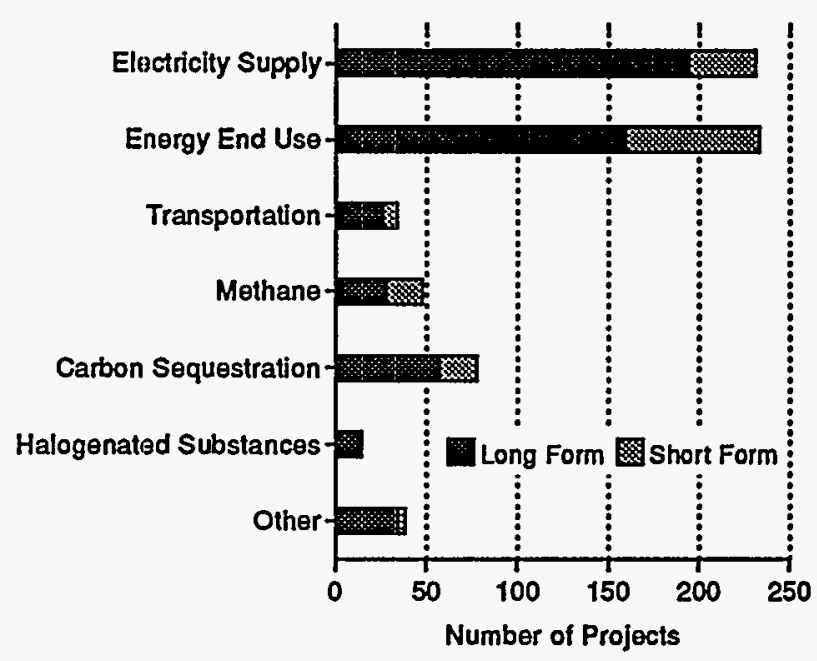

Source: Energy Information Administration, Forms EIA-1605 and EIA-1605EZ, "Voluntary Reporting of Greenhouse Gases" (1995 reporting cycle).

The reports submitted to the EIA have been compiled into a database, which will be released to the public contemporaneously with the release of this report, in the form of a CD-ROM for computers running Microsoft Windows. Persons interested in obtaining a copy of the database may contact the EIA at 1-800-803-5182, or via e-mail at infoghg@eia.doe.gov. 


\section{The Voluntary Reporting Program: An Overview}

\section{Introduction}

Rising global atmospheric concentrations of carbon dioxide, methane, nitrous oxide, and other "greenhouse gases" have been a subject of increasing scientific and policy concern for the past decade. Many scientists and policymakers believe that increasing atmospheric concentrations of these gases (thought to be caused by human activities, particularly the combustion of fossil fuels) may cause significant long-term changes in global weather and climate by trapping more of the sun's heat within the atmosphere. The heat trapping properties of greenhouse gases are discussed in the box on page 2 .

In 1992, President Bush signed a multilateral treaty, the Framework Convention on Climate Change, which committed the United States to take steps, in conjunction with other signatory states, to ". . achieve... stabilization of the greenhouse gas concentrations in the atmosphere at a level that would prevent dangerous anthropogenic interference with the climate system."1

As the Framework Convention was being negotiated, the Congress began to consider measures that would help the U.S. Government develop the national "commitmen $t^{\prime \prime}$ required by the treaty. One such measure was Section 1605(b) of the Energy Policy Act of 1992, which requires the Energy Information Administration (EIA) to create reporting forms and a database for the voluntary reporting of emissions and reductions in emissions of greenhouse gases.

The Voluntary Reporting Program was developed in a cooperative effort with potential reporters, the Department of Energy's Office of Policy, and the U.S. Environmental Protection Agency. The program permits individuals, corporations, and other organizations to report to the EIA on actions taken that have reduced emissions of greenhouse gases. Reporters have chosen to undertake the considerable effort of preparing their submissions for several reasons:
- To establish a public record of their voluntary contribution to achieving a national policy objective

- To provide the opportunity for others to benefit from their experience in reducing emissions

- To demonstrate their commitment to voluntary approaches to solving or ameliorating environmental conditions

- To record the activities undertaken pursuant to voluntary programs under the President's Climate Change Action Plan

- To create a presumption of "standing" in a possible future regulatory scheme to stabilize or reduce national emissions of greenhouse gases.

This report describes the development of the program and documents the reports received during the program's first reporting year.

\section{Plan of the Report}

This report is divided into four chapters:

- Chapter 1 describes the development of the Voluntary Reporting Program and the design of the reporting system, characterizing the types of reports received.

- Chapter 2 provides an overview of participation in the program by the 40 entities and individuals (reporters) who reported on the aggregate emissions of their organizations. The 40 organizations include the largest electric utilities in the United States.

- Chapter 3 reviews and categorizes the 645 emissions reduction projects reported by program participants. The projects range from improving the availability of nuclear power plants to tropical forest preservation projects.

- Chapter 4 describes some of the emissions accounting issues that were addressed by the reporters and the EIA in developing the Voluntary Reporting Program.

\footnotetext{
${ }^{1}$ United Nations, "Report of the Intergovernmental Negotiating Committee for a Framework on Convention for Climate Change on the Work of the Second Part of its Fifth Session, Held at New York from 30 April to 9 May 1992," UN Document A/AC.237/18, Part II (May 15, 1992).
} 


\section{What Are Greenhouse Gases?}

Many chemicals found in the Earth's atmosphere act as "greenhouse gases," which received their appellation because they tend to be.transparent to sunlight radiated largely in the visible and ultraviolet spectra, whereas they tend to absorb infrared radiation (heat) that is radiated back into the atmosphere from the Earth's surface. This process traps the heat from sunlight at, or close to, the Earth's surface and significantly raises the average temperature of the planet. Many gases that occur naturally in the atmosphere exhibit such "greenhouse" properties, including water vapor, carbon dioxide, methane, nitrous oxide, and an array of largely manufactured halogenated substances. Other gases have so-called "indirect effects" on global warming, because they may contribute to the buildup or decomposition of other greenhouse gases in the atmosphere. For instance, some urban air pollutants (nitrogen oxides and nonmethane volatile organic compounds) react in the presence of sunlight to create ozone $\left(\mathrm{O}_{3}\right)$, which is also a greenhouse gas. Sulfur dioxide may have a net cooling effect by promoting cloud formation, while chlorofluorocarbons and hydrochlorofluorocarbons have a direct warming effect that is offset to some unknown degree by an indirect cooling effect caused by their propensity to destroy ozone in the stratosphere.

Atmospheric concentrations of several important greenhouse gases (carbon dioxide, methane, nitrous oxide, and most halogenated substances) have been increasing exponentially for many years. The growth in their concentrations is believed to be caused by human activities-particularly, by the burning of fossil fuels and by deforestation. In recent years, some scientists and policymakers have become concerned that the buildup of greenhouse gases in the atmosphere may increase the share of the sun's heat retained in the atmosphere, which in turn may affect the Earth's climate in uncertain but potentially disruptive ways.

Some greenhouse gases are more effective in trapping reflected infrared radiation than others. Since policymakers need to know on which gases their efforts should be concentrated, scientists working with the Intergovernmental Panel on Climate Change (IPCC) have engaged in efforts to develop an index of the relative marginal heat-trapping capacities of various greenhouse gases. This index, called a "global warming potential" (GWP), is intended to measure only the marginal direct radiative forcing of greenhouse gases, ignoring most indirect effects, which proved too complex and uncertain to incorporate in the GWP measure. GWPs are calculated on the basis of the radiative forcing ability of a unit of carbon dioxide, which is set equal to 1 , integrated over periods of 20 , 100 , and 500 years.

The IPCC periodically revises its GWP calculations. The table below shows the most recent (1994) 100-year GWPs for some of the most important greenhouse gases. The IPCC indicates that the typical uncertainty for these estimates is \pm 35 percent.

Numerical Estimates of 100-Year Global Warming Potential Relative to Carbon Dioxide

(Carbon Dioxide $=1$ )

\begin{tabular}{|c|c|}
\hline Gas & $\begin{array}{c}\text { 100-Year } \\
\text { Global Warming } \\
\text { Potential }\end{array}$ \\
\hline Carbon Dibxide ............ & 1 \\
\hline Methane $\ldots \ldots \ldots \ldots \ldots \ldots$ & 24.5 \\
\hline Nitrous Oxide $\ldots \ldots \ldots \ldots \ldots$ & 320 \\
\hline \multicolumn{2}{|l|}{ Halogenated Substances } \\
\hline CFC-11 $\ldots \ldots \ldots \ldots \ldots$ & 4,000 \\
\hline CFC-12 $\ldots \ldots \ldots \ldots \ldots \ldots$ & 8,500 \\
\hline CFC-113 $\ldots \ldots \ldots \ldots \ldots$ & 5,000 \\
\hline CFC-114 $\ldots \ldots \ldots \ldots \ldots$ & 9,300 \\
\hline CFC-115 $\ldots \ldots \ldots \ldots$ & 9,300 \\
\hline Halon $1301 \ldots \ldots \ldots \ldots$ & 5,600 \\
\hline HCFC-22 $\ldots \ldots \ldots \ldots \ldots \ldots$ & 1,700 \\
\hline HCFC-123 $\ldots \ldots \ldots \ldots \ldots$ & 93 \\
\hline HCFC-124 $\ldots \ldots \ldots \ldots \ldots$ & 480 \\
\hline HCFC-141b $\ldots \ldots \ldots \ldots \ldots$ & 630 \\
\hline HCFC-142b $\ldots \ldots \ldots \ldots \ldots$ & 2,000 \\
\hline HFC-23 $\ldots \ldots \ldots \ldots \ldots \ldots$ & 12,100 \\
\hline HFC-125 $\ldots \ldots \ldots \ldots \ldots$ & 3,200 \\
\hline HFC-134a $\ldots \ldots \ldots \ldots \ldots$ & 1,300 \\
\hline HFC-152a $\ldots \ldots \ldots \ldots \ldots$ & 140 \\
\hline HFC-227ıa $\ldots \ldots \ldots \ldots \ldots$ & 3,300 \\
\hline Perfluoromethane ......... & 6,300 \\
\hline Perfluororthane $\ldots \ldots \ldots \ldots$ & 12,500 \\
\hline Carbon Tetrachloride $\ldots \ldots \ldots$ & 1,400 \\
\hline Methyl Chloroform . . . . . . . & 110 \\
\hline Methyl Chloride .......... & 9 \\
\hline Chloroform $\ldots \ldots \ldots \ldots \ldots$ & 5 \\
\hline Sulfur Hexafluoride $\ldots \ldots \ldots \ldots$ & 24,900 \\
\hline
\end{tabular}




\section{Development of the Voluntary Reporting Program}

The Voluntary Reporting Program is required by Section 1605(b) of the Energy Policy Act of 1992 (see box on page 4). More than 3 years elapsed from the passage of the law, in October 1992, to the completion of the first reporting cycle. The development of the Voluntary Reporting Program consisted of three phases:

- Guidelines development (October 1992 to October 1994)

- Forms development (February 1994 to July 1995)

- Report processing (July 1995 to March 1996).

\section{Guidelines Development}

The principal clauses of Section 1605(b) of the Energy Policy Act require the U.S. Department of Energy (DOE), in consultation with the U.S. Environmental Protection Agency (EPA), to issue guidelines for reporting emissions of greenhouse gases. The EIA was then required to develop a reporting framework consistent with the guidelines. The information collected was to be accessible for public use.

The development of the guidelines was assigned to DOE's Office of Policy, which began a series of public workshops to gather information about public expectations of the program. The public workshops on the guidelines ran from September 1993 to March 1994 and were held in Washington, DC, Atlanta, GA, and Chicago, IL. The workshops spanned a range of issues relating to the objectives of the Voluntary Reporting Program, the definition of a "credible" report, and methods of reporting.

On April 21, 1993 (Earth Day), President Clinton committed the United States to stabilizing its emissions of greenhouse gases at 1990 levels by the year 2000. The methods by which the Government proposes to achieve this objective were described in the President's Climate Change Action Plan, published in October 1993. ${ }^{2}$ That document spells out a range of largely voluntary programs intended to limit emissions of greenhouse gases. Readers may also wish to consult the Action Plan's Technical Supplement, published in early 1994, which describes the assumptions underlying the Plan in greater detail. ${ }^{3}$
Differing notions of the purpose of the Voluntary Reporting Program were expressed, as well as differing views about the nature and type of information to be collected. Many potential reporters tended to stress the notion that the reporting system should be "simple and flexible." They typically opposed suggestions to construct detailed "official" definitions of baselines, reporting entities, and coverage of reports. It was argued that such definitions were premature in an experimental program, would discourage companies from reporting, and would render the program relatively narrow.

Some commenters argued the reverse. They urged explicit and specific definitions of "who is responsible for an emission." The individuals and organizations holding these views hoped to elicit reports that revealed absolute and verifiable emissions reductions.

Following the workshops, a public review draft of the guidelines was published in May 1994. After further public comment, final guidelines were published in October $1994 .^{4}$

The guidelines contain several broad themes that have shaped the program:

- The Department held that the primary objective of the program was "broad participation." Any U.S. "legal person" (i.e., individual, corporation, trade association, or private voluntary organization) may report.

- Within the confines of the statute, reporters were given nearly complete flexibility in crafting their reports. Reporters were free to define as they saw fit the nature of the reporting entity, the emissions and reductions to be reported, methods of calculating emissions and reductions, and the type of activity deemed to cause emissions reductions.

- Reporters were to be permitted to report on activities both in the United States and abroad, so long as they distinguish between domestic and foreign activities.

- Reporters were to be encouraged to report both emissions and emissions reductions as comprehensively as possible, accounting for both "direct" and "indirect" emissions, and also for "primary" and "secondary" effects. These terms are further defined below.

\footnotetext{
${ }^{2}$ President William J. Clinton, The Climate Change Action Plan (Washington, DC, October 1993), p. i.

3U.S. Department of Energy, The Climate Change Action Plan: Technical Supplement, DOE/PO-0011 (Washington DC, March 1994).

${ }^{4}$ U.S. Department of Energy, Voluntary Reporting of Greenhouse Gases Under Section 1605(b) of the Energy Policy Act of 1992: General Guidelines, and Sector-Specific Issues and Reporting Methodologies Supporting the General Guidelines for the Voluntary Reporting of Greenhouse Gases Under Section 1605(b) of the Energy Policy Act of 1992, Volumes 1 and 2, DOE/PO-0028 (Washington, DC, October 1994).
} 


\section{The Energy Policy Act of 1992, Sections 1605(b) and (c)}

(B) Voluntary Reporting.-

(1) ISSUANCE OF GUIDELINES.-Not later than 18 months after the date of the enactment of this Act, the Secretary shall, after opportunity for public comment, issue guidelines for the voluntary collection and reporting of information on sources of greenhouse gases. Such guidelines shall establish procedures for the accurate voluntary reporting of information on-

(A) greenhouse gas emissions-

(i) for the baseline period of 1987 through 1990; and

(ii) for subsequent calendar years on an annual basis;

(B) annual reductions of greenhouse gas emissions and carbon fixation achieved through any measures, including fuel switching, forest management practices, tree planting, use of renewable energy, manufacture or use of vehicles with reduced greenhouse gas emissions, appliance efficiency, methane recovery, cogeneration, chlorofluorocarbon capture and replacement, and power plant heat rate improvement;

(C) reductions in greenhouse gas emissions achieved as a result of-

(i) voluntary reductions;

(ii) plant or facility closings; and

(iii) State or Federal requirements; and

(D) an aggregate calculation of greenhouse gas emissions by each reporting entity.
Such guidelines shall also establish procedures for taking into account the differential radiative activity and atmospheric lifetimes of each greenhouse gas.

(2) REPORTING PROCEDURES.-The Administrator of the Energy Information Administration shall develop forms for voluntary reporting under the guidelines established under paragraph (1), and shall make such forms available to entities wishing to report such information. Persons reporting under this subsection shall certify the accuracy of the information reported.

(3) CONFIDENTIALITY.-Trade secret and commercial or financial information that is privileged or confidential shall be protected as provided in section $552(\mathrm{~b})(4)$ of title 5 , United States Code.

(4) ESTABLISHMENT OF DATA BASE.-Not later than 18 months after the date of the enactment of this Act, the Secretary through the Administrator of the Energy Information Adrninistration shall establish a data base comprised of information voluntarily reported under this subsection. Such information may be used by the reporting entity to demonstrate achieved reductions of greenhouse gases.

\section{(C) Consultation.-}

In carrying out this section, the Secretary shall consult, as appropriate, with the Administrator of the Environmental Protection Agency.
- Reporters were to be encouraged to report on emissions and emissions reductions for a range of greenhouse gases.

- Reporters were to be permitted to report "achieved reductions," defined as emissions reductions achieved since 1990.

The guidelines did not define "property rights" in emissions. For example, the emissions from generating electricity could be the responsibility of an electric utility or the purchaser of the electricity. By accepting the validity of differing possible interpretations of who "owns" emissions, reporters were given considerable flexibility in reporting on their greenhouse gas emissions and emissions reduction activities. The guidelines explicitly recognized the possibility that, in the absence of clear "property rights," two or more organizations might report on the same emissions reduction activity, an eventuality called "double reporting." The flexibility of the guidelines has, of necessity, resulted in a relatively complex reporting form and database.

\section{Forms Development}

The EIA developed, in parallel, reporting. forms and a database consistent with the guidelines. In early November 1994, 2 weeks after the issuance of the final guidelines, the EIA issued draft forms for public review. The draft forms were pre-tested by several firms interested in reporting, including Niagara 
Mohawk Power, Houston Light \& Power, and General Motors. Many useful comments were received, both from pre-testers and from the public review process.

Following the public review, the EIA sent the forms to the Office of Management and Budget (OMB) for formal clearance under the Paperwork Reduction Act, a legal requirement for any Federal data collection exercise. The OMB requested further public comment and, after reviewing the forms, cleared them for public use in May 1995. After final editing and layout revisions to enhance readability, the EIA released the forms to the public in July 1995.

\section{The Voluntary Reporting Program and the Climate Change Action Plan}

As the President's Climate Change Action Plan got underway, managers of certain DOE- and EPAsponsored voluntary emissions reduction programs (as well as some participants) felt the need for a reporting system to record and describe the actions of participants in those programs. The 1605(b) Voluntary Reporting Program, already underway with an OMBapproved data collection instrument and a requirement to collect information about a broad range of emissions reduction activities, turned out to be a useful vehicle for recording results of the voluntary reduction programs. Participants in the "Climate Challenge" program (for electric utilities) and the "Climate Wise" program (for manufacturing firms) are strongly encouraged to file reports documenting their emissions reduction efforts with the Voluntary Reporting Program. ${ }^{5}$

\section{Forms Design}

The data collection forms for the Voluntary Reporting Program, as developed, endeavor to cover the complexity in categories of emissions required by the guidelines. To this end, the structure of the voluntary reporting database needed to be expansible to cover many different contingencies, including the following:

- Reporters ranged from some of the largest industrial firms in the United States to individual households and voluntary organizations.

- Reporters could report on particular actions they had taken to reduce emissions or on the emissions (and reductions) of their entire organizations.
- The statute required, and reporters requested, the ability to report on many different classes of actions that have the effect of reducing greenhouse gas emissions, ranging from energy conservation to carbon sequestration.

- The reporting format seeks to identify areas where multiple reporting of the same project actually occurs, and to make possible a general assessment of the reliability and possible ownership of the reports.

- The lack of generally accepted accounting principles for greenhouse gas emissions requires a design that permits a variety of reporting formats. This led to ambiguities that the forms design tried to clarify.

- The guidelines permit the reporting of foreign emissions reduction actions.

- The guidelines permit reporting on reductions for a range of greenhouse gases.

- Managers of voluntary programs asked the EIA to develop a mechanism for collecting participants' commitments to reduce future emissions.

The EIA developed two alternative reporting instruments: the long form (Form EIA-1605), which comprises four schedules (described in the box on page 6), and the short form (Form EIA-1605EZ). The short form is intended to cover reporting solely on emissions reduction projects and for a single year only.

The text box on page 6 outlines the basic structure of the long form. The form has four schedules. The first schedule simply asks for the name and address of the reporter, along with some particulars about the report. The most fundamental distinction is between "project reporting" in Schedule II, and "entity reporting" in Schedule III. Project reporters are reporting on specific actions they have taken to reduce emissions. Entity reporters are reporting on emissions and emissions reductions for an entire organization. Forty reporters provided entity reports, and ninety-nine reporters provided project reports. Thirty-one reporters filed both entity and project reports, while nine reporters filed only entity reports. No reporter found it necessary to fill out the complete form. Within Schedule II, the report is further subdivided into ten sections, reflecting the diversity of anticipated reduction actions. Each section contains questions specific to the particular type of project, to help reporters and the EIA understand and describe the project.

\footnotetext{
${ }^{5}$ Not all participants in those programs have filed $1605(\mathrm{~b})$ reports. Many participants have promised to take actions in the future, which will not be reportable until the actions have produced results. Section 1605(b) obliges the EIA to receive reports of "achieved reductions," meaning the results of actions already taken. Further, many participants joined the voluntary programs after the close of the 1995 reporting cycle. Finally, some voluntary program participants may have experienced difficulty in gathering together the necessary information to file their reports.
} 




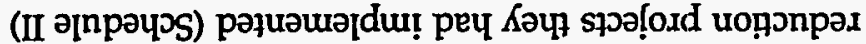

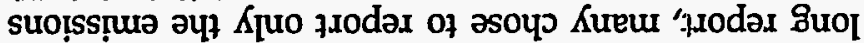

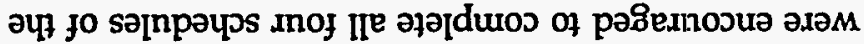

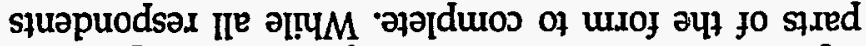

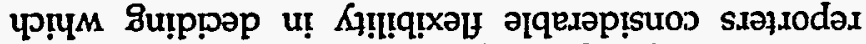

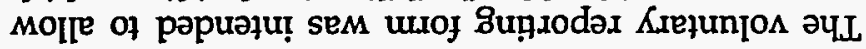

$\checkmark r$ xipuədd $\forall$ ut pəpụoxd s! s.xəł.

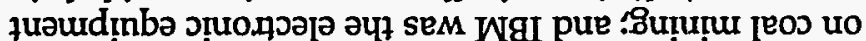
pajxodax Кpoqead 'еoग to uo!sutp sungerado ue pue

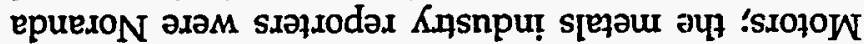

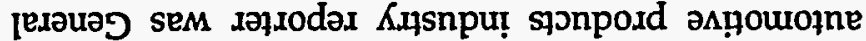

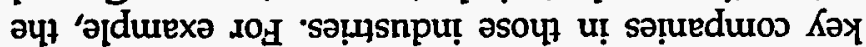

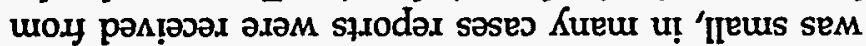

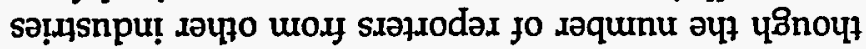

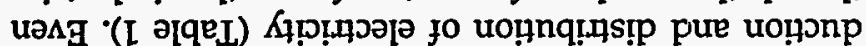

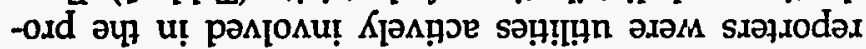

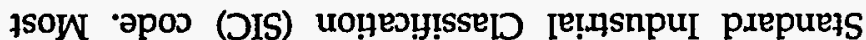

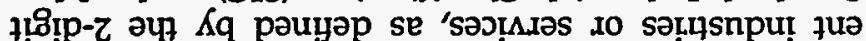

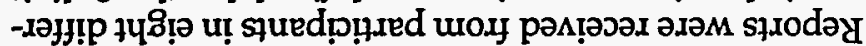

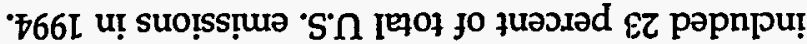



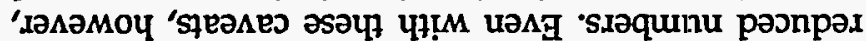

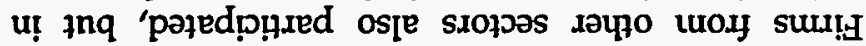

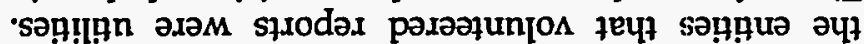

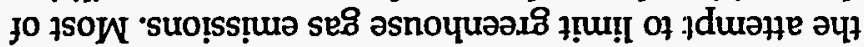

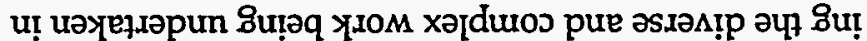
-7.

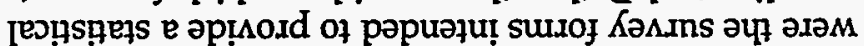

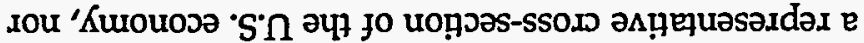

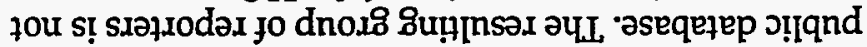

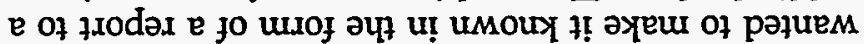

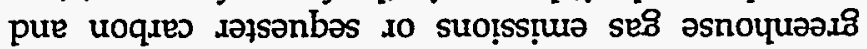

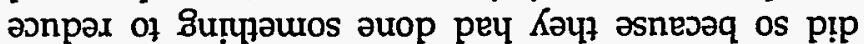

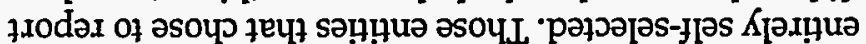
әләм uresoosd 8ụ̣.

\section{pəнодәу ОчM}

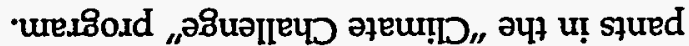

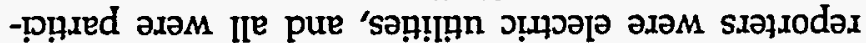

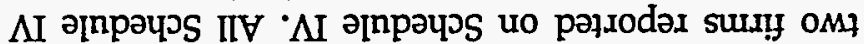

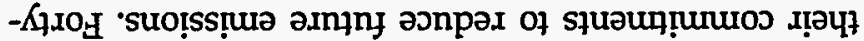

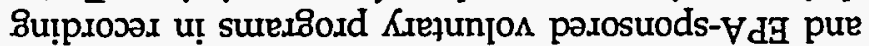

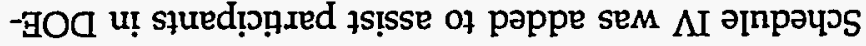

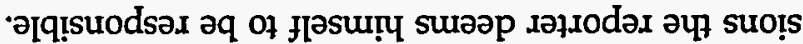

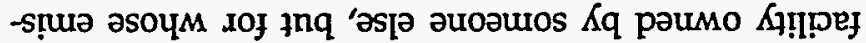

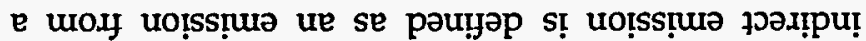

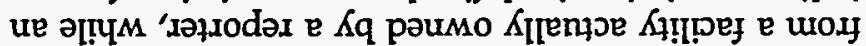



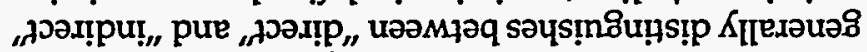

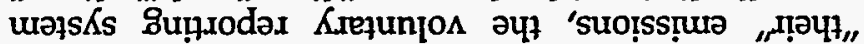

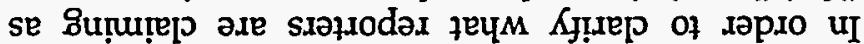

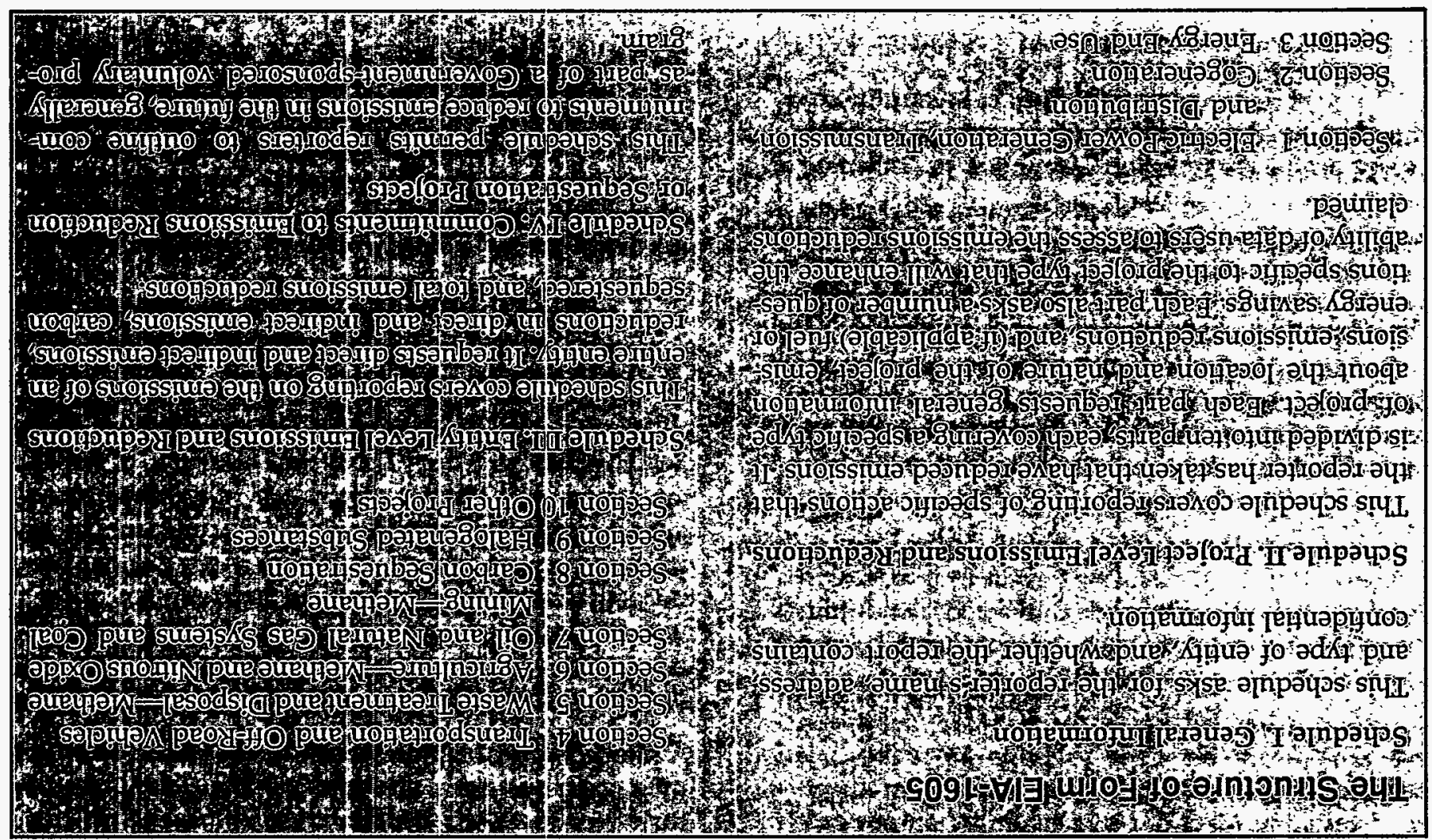


Table 1. Reports Received, by Standard Industrial Classification and Report Type (Number of Reports)

\begin{tabular}{|c|c|c|c|c|}
\hline \multirow[b]{2}{*}{ SIC Code } & \multirow[b]{2}{*}{ Description } & \multicolumn{2}{|c|}{ Type of Form Filed } & \multirow[b]{2}{*}{ Total } \\
\hline & & Long Form & Short Form & \\
\hline 08 & Forestry $\ldots \ldots \ldots \ldots \ldots \ldots \ldots \ldots$ & 1 & 0 & 1 \\
\hline 12 & Coal Mining $\ldots \ldots \ldots \ldots \ldots$ & 1 & 0 & 1 \\
\hline 28 & Chemical and Allied Products & 1 & 0 & 1 \\
\hline 33 & Primary Metals $\ldots \ldots \ldots \ldots \ldots \ldots$ & 2 & 0 & 2 \\
\hline 36 & Electronic Equipment $\ldots$... & 1 & 0 & 1 \\
\hline 37 & Transportation Equipment..$\ldots \ldots \ldots \ldots$ & 1 & 0 & 1 \\
\hline 49 & Electric, Gas, and Sanitary Services........ & 64 & 34 & 98 \\
\hline 82 & Educational Services ................ & 1 & 0 & 1 \\
\hline 88 & Private Households . . . . . . . . . . . . & 1 & 1 & 2 \\
\hline Total .. & & 73 & 35 & 108 \\
\hline
\end{tabular}

Source: Energy Information Administration, Forms EIA-1605 (long form) and EIA-1605EZ (short form), "Voluntary Reporting of Greenhouse Gases" (1995 reporting cycle).

emissions (Schedule III) or their commitments to implement projects in the future (Schedule IV). In all, the EIA received 40 entity-wide reports on Schedule III, 99 reports on projects on Schedule II, and 42 reports of commitments to make future reductions on Schedule IV. The Schedule II (project) reporters accounted for 645 individual projects, most of which were energy end use and electric power generation and transmission projects (Table 2). More information on the entity-wide reports can be found in Chapter 2, and more information on the project reports can be found in Chapter 3 of this report. Nine reporters omitted Schedule II altogether and reported at the entity-wide level. For reporters using the short form, since only project information was collected, no entity-level emissions data were reported.

Reports were received from 39 States, with no particular geographic concentration, although more reports were received from the Midwest and Northeast than from other regions. The emissions reduction activities covered by the reports were overwhelmingly domestic. All reports on the short form, by definition, covered only domestic projects, and 70 of the 73 long forms reported exclusively domestic emissions reduction data. Of the remaining 3 reporters, 1 reported a combination of domestic and foreign emissions reduction activities, and 2 reports covered only foreign activities.

Most of the entities that reported were corporations. Of the 56 corporate reporters using the long form and providing additional detail about their organizations, 41 were publicly traded companies, 4 were privately held, 5 were nonprofit, and 6 were subsidiaries of larger
Table 2. Distribution of Reports Received by Category of Information Reported

\begin{tabular}{|c|c|c|}
\hline Project Type & $\begin{array}{l}\text { Number of } \\
\text { Reporters }\end{array}$ & $\begin{array}{c}\text { Number of } \\
\text { Projects }\end{array}$ \\
\hline Electricity Generation & 72 & 224 \\
\hline Cogeneration $\ldots \ldots \ldots \ldots$ & 5 & 7 \\
\hline Energy End Use $\ldots \ldots \ldots \ldots$ & 77 & 207 \\
\hline Transportation $\ldots \ldots \ldots \ldots$ & 26 & 33 \\
\hline Methane: Waste Treatment ... & 12 & 27 \\
\hline Methane: Agriculture ........ & 2 & 3 \\
\hline Methane: Energy Production .. & 8 & 13 \\
\hline Carbon Sequestration & 40 & 78 \\
\hline Halogenated Substances . . . . . & 13 & 15 \\
\hline Other Emissions Reduction ... & 33 & 38 \\
\hline All Categories .......... & 99 & 645 \\
\hline Did Not Report Projects...... & 9 & - \\
\hline All Reporters ........... & 108 & 645 \\
\hline
\end{tabular}

Source: Energy Information Administration, Forms ElA-1605 and EIA-1605EZ, "Voluntary Reporting of Greenhouse Gases" (1995 reporting cycle).

firms. Twelve government entities-most of them municipal electric utilities or regional associations of municipal utilities-also reported. The Tennessee Valley Authority was the only Federal entity that reported. Two households also reported.

Most reporters indicated that their projects were affiliated with one or more government-sponsored voluntary program. Of the 645 total projects reported, 
556 were identified as being affiliated with the Climate Challenge Program, 15 with EPA's Green Lights Program, and 6 with the Landfill Methane Outreach Program. Other voluntary programs mentioned included Energy Star Computers, Energy Star Transformers, the U.S. Initiative on Joint Implementation, the Voluntary Aluminum Industrial Partnership, Climate Wise, and
Waste Wise. The preponderance of Climate Challenge affiliations resulted from a requirement in the Climate Challenge accord between DOE and participating utilities that each utility would file reports consistent with the 1605 (b) program. The three manufacturers that reported (General Motors, Johnson \& Johnson, and IBM) were participants in the Climate Wise program. 


\section{Entity-Level Reports}

\section{National Greenhouse Gas Emissions Trends}

Table 3 shows estimated 1987-1994 U.S. anthropogenic emissions of greenhouse gases. Carbon dioxide emissions have been rising slowly since 1991. After applying global warming potentials (GWPs), GWPweighted emissions of all greenhouse gases have also risen since 1991 and remain above 1990 levels. The Energy Information Administration (EIA) forecasts that carbon dioxide emissions will continue to rise at a 1percent annual rate between 1994 and 2000. ${ }^{6}$ The largest source of anthropogenic emissions is the combustion of fossil fuels. The amount of fossil fuel consumed by the U.S. economy is determined by an array of short-term and long-term factors, including the rates of population and economic growth, changes in technology and in the composition of economic activity, the weather, fuel prices, and the availability of nonfossil fuels (principally nuclear and hydroelectric power). When studying the reports of emissions reductions filed with the Voluntary Reporting Program, readers should bear in mind that total national emissions are rising.

\section{Entity-Level Emissions}

\section{Background}

The coverage of Form EIA-1605 includes both project and entity-level reporting. The focus of this section is on the total emissions produced by entities as reported on Schedule III. The data to be reported at the entity level are grouped by:

- Greenhouse gas

- Whether the reported emissions and reductions are direct or indirect

- Whether the source of the emissions and reductions is stationary combustion, transportation, or some other source

- Whether the source of the emissions and reductions is domestic or foreign.

The period covered for reporting emissions is divided into the baseline years (1987 to 1990) and annual report years (1990 to 1994). The reporting of indirect emissions and reductions accounts for the emissions effects of

Table 3. Estimated U.S. Emissions of Greenhouse Gases, 1987-1994

(Million Metric Tons of Gas)

\begin{tabular}{|c|c|c|c|c|c|c|c|c|}
\hline Gas & 1987 & 1988 & 1989 & 1990 & 1991 & 1992 & 1993 & 1994 \\
\hline Carbon Dioxide ............ & $4,820.6$ & $5,046.1$ & $5,080.7$ & $5,035.5$ & $4,988.1$ & $5,062.9$ & $5,156.0$ & $5,243.4$ \\
\hline Methane........ & 27.0 & 27.6 & 27.6 & 27.9 & 27.9 & 28.0 & 26.6 & NA \\
\hline Nitrous Oxide ........... & 0.4 & 0.4 & 0.4 & 0.4 & 0.4 & 0.4 & 0.5 & NA \\
\hline HFCs and PFCs .......... & * & * & * & * & * & * & * & * \\
\hline CFC-11, CFC-12, CFC-113 ... & 0.3 & 0.3 & 0.3 & 0.2 & 0.2 & 0.2 & 0.2 & 0.1 \\
\hline HCFC-22 . . . . & 0.1 & 0.1 & 0.1 & 0.1 & 0.1 & 0.1 & 0.1 & 0.1 \\
\hline Methyl Chloroform ......... & 0.3 & 0.3 & 0.3 & 0.3 & 0.2 & 0.2 & 0.2 & 0.1 \\
\hline
\end{tabular}

"Less than 50,000 metric tons of gas.

$N A=$ not available.

Note: Data for 1994 are preliminary.

Source: Energy Information Administration, Emissions of Greenhouse Gases in the United States 1987-1994, DOE/EIA0573(87-94) (Washington, DC, October 1995), Table ES1, p. ix. 
sales and purchases of electricity. A total of 40 reporters chose to provide entity-level emissions data, and 36 reported reduction data.

Caution must be used when evaluating the entity-level data provided by participants in the Voluntary Reporting Program. It is potentially misleading to sum items reported on Schedule III, because not all items are comparable between reporters. Direct and indirect reductions, for instance, are not necessarily comparable across companies, because there are several equally legitimate ways to calculate the extent of emissions reductions for a given gas, depending on the type of reference case used by the reporter. A reporter's reference case (the standard of comparison for defining a reduction) may refer to emissions in some historical year, or it may refer to what might have happened in the absence of particular actions. Also, more than one reporter may have reported on the same action.

As a result, the sum of emissions or reductions reported under this program cannot be properly compared with national-level emissions to measure the success of the reporting firms in achieving national-level emissions targets. However, the sums do provide a useful indicator of the gross coverage and scale of voluntary reporting and, therefore, are included in this report. With these caveats in mind, however, it is instructive to examine some of the aggregate statistics derived from entity-level reporting, as they give considerable insight into the scale and coverage of the reports received by the Voluntary Reporting Program.

\section{Emissions Levels}

\section{Carbon Dioxide}

All entity-level reporters included information on carbon dioxide emissions. Most entity-level reporters ( 37 out of 40) were electric utilities, including most of the largest U.S. fossil-fuel-burning electric utilities. The other three entity-level reporters were General Motors, Peabody Holding Company, and one household.

The Southern Company had the largest reported total of carbon dioxide emissions from fossil fuel, indicating direct emissions of 97 million metric tons from stationary combustion in 1994, followed by the Tennessee Valley Authority, with emisșions of $\mathbf{7 7}$ million metric tons, Cinergy with 42 million metric tons, and Allegheny Power Service Corporation with 40 million metric tons.

While the combustion of any fossil fuel results in some level of carbon dioxide emissions, emissions per kilowatthour of power generated can vary considerably, depending on the thermal efficiency of power generation and the particular fossil fuel used (carbon-rich coal produces about 60 percent more emissions per unit of energy input than natural gas, and the most modern gas- or, oil-fired combined-cycle power plants can produce 30 to 50 percent more electricity per unit of fuel input than older steam turbine plants).

Many of the projects reported by utilities involved efforts to reduce coal consumption through fuel switching, demand-side reduction, and equipment improvements that reduce the amount of coal required to achieve a given level of electricity production. Some of the most significant emissions reductions came from entities such as Texas Utilities and Detroit Edison, which either brought nuclear plants on line during the reporting period or implemented programs to increase the baseload availability of nuclear units.

Electric utilities were not the only reporters of large carbon dioxide emissions. The second major national source of carbon dioxide, those emissions resulting from transportation, were also reported. General Motors (GM) reported as "indirect emissions" the carbon dioxide that resulted from GM-built cars and light trucks being driven during the reporting period. In order to arrive at an annual quantity, GM estimated the number of GM-manufactured cars and light trucks that were on the road between 1987 and 1994, then estimated the average number of miles that the "GM-built fleet" had been driven in each year. Fuel consumption was computed by multiplying miles driven by estimated fuel consumption per mile for each class of vehicle. Emissions were then computed using the standard emission factors published in DOE guidelines.

Reported baseline carbon dioxide emissions from the GM-built fleet declined by more than 100 million metric tons between 1987 and 1994. GM did not claim this decline as a corporate "reduction" on its report. The reported decline in emissions occurred in part because new GM vehicles were consistently much more fuelefficient than the average GM vehicle in operation during 1991-1994. Emissions from GM automobiles declined sharply, while emissions from GM light trucks were roughly stable. The rising number of GM light trucks on. the road offset improvements in fuel efficiency.

Table 4 summarizes entity-level carbon dioxide emissions reported to the Voluntary Reporting Program. The 26 reporters (including 24 electric utilities) that reported entity-wide emissions for the entire 1987-1994 period are grouped together, as are the 14 reporters (13 utilities) that reported entity-wide emissions for 1990-1994. One reporter (Centerior Energy Corporation) reported 
Table 4. Total Carbon Dioxide Emissions Reported to the Voluntary Reporting Program by Type of Activity, 1987-1994

(Thousand Metric Tons of Carbon Dioxide)

\begin{tabular}{|c|c|c|c|c|c|c|c|c|}
\hline Type of Emission & 1987 & 1988 & 1989 & 1990 & 1991 & 1992 & 1993 & 1994 \\
\hline \multicolumn{9}{|c|}{ Reports for $1987-1994$} \\
\hline \multicolumn{9}{|l|}{$\begin{array}{l}\text { Direct Emissions } \\
\text { Stationary Combustion }\end{array}$} \\
\hline Electric Utilities .... . & 570,909 & 592,425 & 589,690 & 588,042 & 583,298 & 562,938 & 590,600 & 589,961 \\
\hline General Motors ... & 6,532 & 6,804 & 6,804 & 5,262 & 4,990 & 4,899 & 5,262 & 5,171 \\
\hline Transportation & 165 & 198 & 199 & 201 & 197 & 196 & 186 & 187 \\
\hline Other $\ldots \ldots \ldots \ldots$ & 60 & 87 & 97 & 95 & 86 & 84 & 82 & 81 \\
\hline $\begin{array}{l}\text { Total Direct Emissions ... } \\
\text { Indirect Emissions }\end{array}$ & 577,665 & 599,514 & 596,790 & 593,600 & 588,570 & 568,117 & 596,130 & 595,400 \\
\hline Purchased Power ......... & 76,737 & 80,622 & 76,108 & 77,119 & 71,932 & 71,001 & 74,301 & 71,241 \\
\hline GM Vehicles . . . . . . . . . . . & 451,510 & 433,004 & 416,856 & 400,435 & 386,193 & 373,855 & 360,337 & 348,181 \\
\hline Total Indirect Emissions .. & 528,247 & 513,626 & 492,963 & 477,555 & 458,125 & 444,855 & 434,639 & 419,422 \\
\hline Total Emissions $\ldots . . \ldots$. & $1,105,913$ & $1,113,140$ & $1,089,753$ & $1,071,155$ & $1,046,695$ & $1,012,973$ & $1,030,769$ & $1,014,822$ \\
\hline Emissions from Power Sales .. & 22,754 & 29,614 & 34,785 & 34,554 & 26,190 & 24,853 & 20,368 & 15,502 \\
\hline $\begin{array}{l}\text { Total Emissions } \\
\text { (Net of Power Sales) . . . . . . }\end{array}$ & $1,083,159$ & $1,083,526$ & $1,054,968$ & $1,036,601$ & $1,020,506$ & 988,120 & $1,010,401$ & 999,320 \\
\hline \multicolumn{9}{|c|}{ Reports for $1990-1994$} \\
\hline $\begin{array}{l}\text { Direct Emissions } \\
\text { Stationary Combustion }\end{array}$ & & & & & & & & \\
\hline Electric Utilities . .... & - & 一 & - & 155,066 & 155,938 & 165,195 & 173,070 & 174,821 \\
\hline Partial Reporters ........ & - & - & - & 20,057 & - & - & - & 75 \\
\hline Transportation & - & - & - & 499 & - & - & - & 425 \\
\hline Total Direct Emissions ... & - & - & - & 175,621 & 155,938 & 165,195 & 173,070 & 175,322 \\
\hline $\begin{array}{l}\text { Indirect Emissions } \\
\text { (Purchased Power) ........ }\end{array}$ & - & - & 一 & 8,738 & 8,471 & 10,247 & 12,750 & 13,575 \\
\hline Total Emissions $\ldots \ldots \ldots$ & - & 一 & 一 & 184,360 & 164,409 & 175,442 & 185,820 & 188,897 \\
\hline Emissions from Power Sales .. & - & 一 & 一 & 9,140 & 10,139 & 13,066 & 14,242 & 15,077 \\
\hline $\begin{array}{l}\text { Total Emissions } \\
\text { (Net of Power Sales) ...... }\end{array}$ & - & - & - & 175,220 & 154,271 & 162,376 & 171,578 & 173,820 \\
\hline
\end{tabular}

- = No data reported.

Notes: Aggregations of estimated emissions and reductions across reporters should be used with caution, since reporters may not calculate emissions and reductions in the same way, and multiple reporters may report on some of the same activities. Totals may not equal sum of components due to independent rounding.

Source: Energy Information Administration, Form ElA-1605, "Voluntary Reporting of Greenhouse Gases" (1995 reporting cycle).

emissions only for 1990, and one reporter (Peabody Holding Company) reported emissions only for 1990 and 1994. Direct and indirect emissions are reported separately. Direct emissions are dominated by the reported emissions of electric utilities, while indirect emissions are composed partly of indirect emissions from purchased power and partly of indirect emissions from $\mathrm{GM}$ vehicles.

There has been considerable discussion, but no consensus, with regard to the accounting treatment of indirect emissions from power sales. As a reporting convention, the Voluntary Reporting Program asks that reporters not subtract net indirect emissions from power sales in calculating their totals. Table 4 also illustrates reported total emissions from the program with and without netting of power sales from total emissions.

\section{Emissions of Other Gases}

Other gases include methane, nitrous oxide, and an array of halogenated substances, such as chlorofluorocarbons (CFCs), hydrochlorofluorocarbons (HCFCs), hydrofluorocarbons (HFCs), and perfluorocarbons (PFCs). "Other gases" that are not halogenates include solvents such as methyl chloroform, but these are not important either as greenhouse gases or as reported substances in the Voluntary Reporting Program. CFCs 
and HCFCs are regulated as ozone-depleting compounds under the Montreal Protocol and the Clean Air Act Amendments of 1990. Manufacture of CFCs in the United States is being phased out. HFCs are CFC substitutes that do not damage the ozone layer; however, they are potent greenhouse gases. This collection of chemicals have diverse uses, including as refrigerants in air conditioning and refrigeration equipment (a common trade name for CFC-12 is "Freon-12"), solvents, and blowing agents for foams.

Table 5 summarizes the reported emissions of other gases. Since all the reports on emissions of gases other than carbon dioxide (by eight firms, including six utilities) included emissions data for each year from 1987 to 1994, Table 5 does not show different classes of reporters. Table 6 shows the emissions of each gas converted into carbon dioxide equivalents, using the "100-year integration" global warming potentials listed in the text box in Chapter 1 (page 2). Emissions of other gases are dominated by indirect emissions of CFC-12, nitrous oxide, and methane, which are almost entirely accounted for by GM's reporting of indirect emissions from GM-built vehicles.

Reported direct methane emissions from stationary combustion are not reliable. The results are dominated by emissions from a single, relatively small reporter, which may have made a calculation error. Leaving aside this figure, direct emissions of other gases are dominated by rapidly declining emissions of CFC-113 and methyl chloroform. GM formerly used these ozonedepleting compounds as solvents but has rapidly been phasing out their use.

Total emissions of other gases (as reported to the Voluntary Reporting Program) are dominated by GM's reporting of indirect emissions from U.S. vehicles, including methane, nitrous oxide, CFC-12, and HFC-134a.

Table 5. Total Emissions of Other Gases Reported to the Voluntary Reporting Program, 1987-1994 (Metric Tons of Gas)

\begin{tabular}{|c|c|c|c|c|c|c|c|c|}
\hline Gas & 1987 & 1988 & 1989 & 1990 & 1991 & 1992 & 1993 & 1994 \\
\hline \multicolumn{9}{|l|}{ Methane } \\
\hline \multicolumn{9}{|l|}{ Direct Emissions } \\
\hline Stationary Combustion .... & 50,041 & 76,904 & 127,206 & 193,777 & 186,325 & 214,863 & 177,367 & 244,339 \\
\hline Transportation ......... & 19 & 19 & 19 & 19 & 19 & 19 & 19 & 19 \\
\hline Other $\ldots \ldots \ldots \ldots \ldots$ & 24,557 & 37,158 & 41,269 & 39,644 & 36,525 & 35,700 & 34,965 & 34,386 \\
\hline Total Direct $\ldots . . . \ldots$ & 74,616 & 114,080 & 168,494 & 233,440 & 222,870 & 250,583 & 212,351 & 278,744 \\
\hline Indirect Emissions .. & 429,395 & 413,112 & 398,823 & $\underline{383,966}$ & $\underline{370,922}$ & 359,717 & 347,363 & $\underline{336,041}$ \\
\hline Total Methane ...... & 504,012 & 527,192 & 567,318 & 617,407 & 593,792 & 610,300 & 559,714 & 614,785 \\
\hline Nitrous Oxide $\ldots \ldots \ldots \ldots$ & 41,823 & 41,369 & 40,916 & 40,099 & 39,283 & 38,648 & 37,741 & 36,924 \\
\hline CFC-11 & 25 & 26 & 28 & 28 & 28 & 29 & 29 & 26 \\
\hline CFC-12 $\ldots \ldots \ldots \ldots$ & 6,023 & 6,015 & 5,980 & 5,851 & 5,647 & 5,447 & 5,109 & 4,527 \\
\hline CFC-113 (Freon 113) & 1,035 & 1,542 & 1,009 & 589 & 550 & 341 & 166 & 39 \\
\hline CFC-114 $\ldots \ldots \ldots \ldots \ldots$ & 2 & 2 & 2 & 2 & 2 & 2 & 2 & 1 \\
\hline HCFC-22 ...... & 19 & 19 & 20 & 20 & 20 & 21 & 12 & 12 \\
\hline HCFC-123 ...... & 0 & 0 & 0 & 0 & 0 & 0 & 0 & • \\
\hline HCFC-141b $\ldots \ldots \ldots \ldots \ldots$ & 0 & 0 & 0 & 0 & 0 & 0 & 0 & 10 \\
\hline Halon $1301 \ldots \ldots \ldots \ldots$ & 1 & 1 & 1 & 1 & 1 & 1 & 1 & 1 \\
\hline HFC-134a $\ldots \ldots \ldots \ldots$ & * & * & * & 1 & 1 & 12 & 184 & 558 \\
\hline HFC-152a $\ldots \ldots \ldots \ldots \ldots$ & 10 & 10 & 10 & 10 & 10 & 10 & 10 & 10 \\
\hline Carbon Tetrachloride........ & 10 & 13 & 8 & 4 & 0 & 0 & 0 & 0 \\
\hline Methyl Chloroform ......... & 2,113 & 1,771 & 1,581 & 944 & 813 & 305 & 186 & 11 \\
\hline Methylene Chloride ........ & 1,165 & 815 & 404 & 136 & 55 & 24 & 9 & 0 \\
\hline
\end{tabular}

"Less than 1 metric ton of gas.

Note: Aggregations of estimated emissions and reductions across reporters should be used with caution, since reporters may not calculate emissions and reductions in the same way, and multiple reporters may report on some of the same activities.

Source: Energy Information Administration, Form ElA-1605, "Voluntary Reporting of Greenhouse Gases" (1995 reporting cycle). 
Table 6. Total Emisslons of Other Gases Reported to the Voluntary Reporting Program, 1987-1994, Welghted by Global Warming Potential

(Thousand Metric Tons Carbon Dioxide Equivalent)

\begin{tabular}{|c|c|c|c|c|c|c|c|c|}
\hline Gas & 1987 & 1988 & 1989 & 1990 & 1991 & 1992 & 1993 & 1994 \\
\hline \multicolumn{9}{|l|}{ Direct Emissions } \\
\hline Methane............. & $1,828.1$ & $2,795.0$ & $4,128.1$ & $5,719.3$ & $5,460.3$ & $6,139.3$ & $5,202.6$ & $6,829.2$ \\
\hline Nitrous Oxide & 0.4 & 0.4 & 0.4 & 0.4 & 0.5 & 0.5 & 0.5 & 0.5 \\
\hline CFC-11 $\ldots \ldots \ldots \ldots \ldots$ & 101.3 & 103.2 & 110.4 & 112.2 & 112.2 & 115.9 & 114.9 & 105.2 \\
\hline CFC-12 $\ldots \ldots \ldots \ldots \ldots$ & 499.7 & 449.6 & 449.6 & 449.6 & 449.6 & 449.6 & 401.4 & 342.3 \\
\hline CFC-113 (Freon 113) ..... & $5,176.4$ & $7,707.8$ & $5,043.6$ & $2,945.4$ & $2,747.9$ & $1,705.9$ & 831.9 & 194.6 \\
\hline CFC-114 $\ldots \ldots \ldots \ldots \ldots$ & 21.1 & 21.1 & 21.1 & 21.1 & 21.1 & 21.1 & 21.1 & 8.4 \\
\hline HCFC-22 & 32.6 & 32.6 & 33.4 & 33.4 & 33.4 & 34.9 & 21.0 & 21.0 \\
\hline HCFC-123 ..... & 0.0 & 0.0 & 0.0 & 0.0 & 0.0 & 0.0 & 0.0 & * \\
\hline HCFC-141b $\ldots \ldots \ldots \ldots$ & 0.0 & 0.0 & 0.0 & 0.0 & 0.0 & 0.0 & 0.0 & 6.3 \\
\hline Halon $1301 \ldots \ldots \ldots$ & 4.0 & 0.0 & 2.8 & 0.0 & 2.0 & 0.0 & 1.4 & 0.0 \\
\hline HFC-134a $\ldots$. & 0.0 & 0.0 & 0.0 & 0.0 & 0.0 & 0.0 & 0.0 & - \\
\hline HFC-152a $\ldots \ldots \ldots \ldots \ldots$ & 1.5 & 1.5 & 1.5 & 1.5 & 1.5 & 1.5 & 1.5 & 1.4 \\
\hline Carbon Tetrachloride ...... & 5.5 & 7.0 & 4.1 & 2.2 & 0.0 & 0.0 & 0.0 & 0.0 \\
\hline Methyl Chloroform & 232.4 & 194.9 & 173.9 & 103.9 & 89.4 & 33.5 & 20.4 & 1.2 \\
\hline Methylene Chloride ....... & 10.5 & 7.3 & 3.6 & 1.2 & 0.5 & 0.2 & 0.1 & * \\
\hline Total Direct Emissions . . . & $7,913.6$ & $11,320.3$ & $9,972.5$ & $9,390.1$ & $8,918.3$ & $8,502.3$ & $6,616.6$ & $7,510.1$ \\
\hline \multicolumn{9}{|l|}{ Indirect Emissions } \\
\hline Methane..... & $10,520.2$ & $10,121.2$ & $9,771.2$ & $9,407.2$ & $9,087.6$ & $8,813.1$ & $8,510.4$ & $8,233.0$ \\
\hline Nitrous Oxide . & $13,382.9$ & $13,237.8$ & $13,092.6$ & $12,831.4$ & $12,570.1$ & $12,366.9$ & $12,076.6$ & $11,815.3$ \\
\hline CFC-12 $\ldots \ldots \ldots \ldots \ldots$ & $50,699.4$ & $50,678.9$ & $50,376.3$ & $49,280.1$ & $47,551.8$ & $45,849.5$ & $43,025.6$ & $38,136.7$ \\
\hline HFC-134a $\ldots \ldots \ldots \ldots \ldots$ & * & 0.1 & 0.3 & 0.7 & 1.2 & 16.2 & 239.6 & 724.8 \\
\hline Total Indirect Emissions .. & $74,602.5$ & $74,038.0$ & $73,240.4$ & $71,519.3$ & $69,210.7$ & $6 \dot{67,045.6}$ & $63,852.2$ & $58,909.8$ \\
\hline Total Reported Emissions ... & $82,516.0$ & $85,358.3$ & $83,212.9$ & $80,909.4$ & $78,129.0$ & $75,547.9$ & $70,468.8$ & $66,419.8$ \\
\hline
\end{tabular}

"Less than 1 metric ton of gas.

Note: Aggregations of estimated emissions and reductions across reporters should be used with caution, since reporters may not calculate emissions and reductions in the same way, and multiple reporters may report on some of the same activities.

Source: Energy Information Administration, Form ElA-1605, "Voluntary Reporting of Greenhouse Gases" (1995 reporting cycle).

\section{Emissions Trends}

Emissions of greenhouse gases reported to the Voluntary Reporting Program show the following trends (Figure 1):

- Direct emissions of carbon dioxide (dominated by utility emissions) show growth in the late 1980s, followed by an abrupt decline from 1990 through 1992. Emissions rose again in 1993 and 1994, but 1994 emissions were within 0.5 percent of the 1990 level. This trend is analogous to the trend for national emissions from the electric utility sector, although emissions growth is slightly stronger at the national level.

- Reported indirect emissions are dominated by GM's report on emissions from its vehicles, which declined steadily from 1987 to 1994 . Reported indirect emissions from purchased power have not changed much (in the aggregate) since 1990.

- Reported emissions of other gases, as noted above, are dominated by declining indirect emissions from GM vehicles, including CFC-12, methane, and nitrous oxide, and by GM's declining direct use of solvents. 
Figure 1. Entity-Level Emissions of Greenhouse Gases by EmIssion Type, 1987-1994

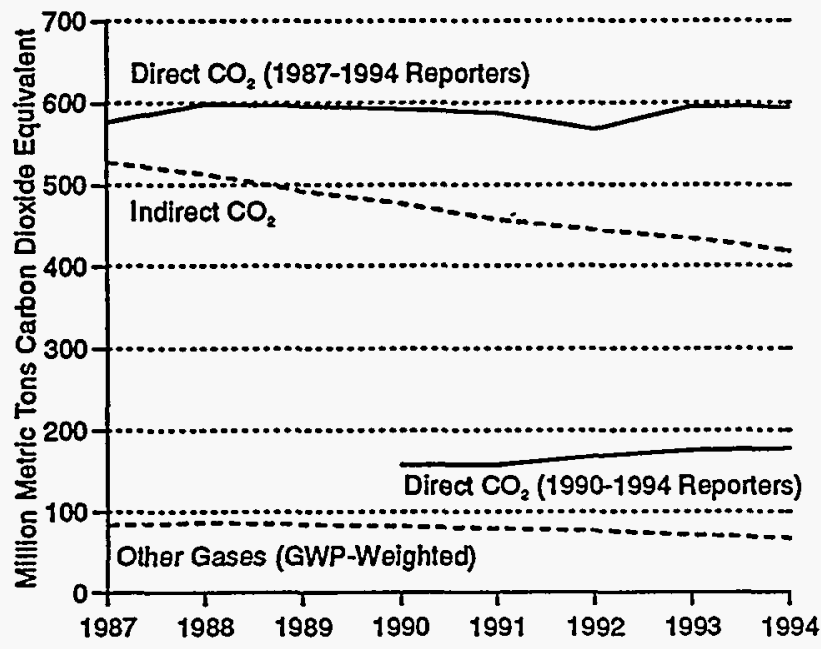

Note: Aggregations of estimated emissions and reductions across reporters should be used with caution, since reporters may not calculate emissions and reductions in the same way, and multiple reporters may report on some of the same activities.

Source: Energy Information Administration, Form EIA-1605, "Voluntary Reporting of Greenhouse Gases" (1995 reporting cycle).

\section{Entity-Level Reductions}

\section{Background}

The significance of emissions trends becomes more evident when emissions reductions are viewed as a percentage of annual reported emissions from the same type of source (that is, when direct reductions are compared with direct emissions and indirect reductions with indirect emissions). With the exception of indirect reductions of carbon dioxide, reporters' reductions are growing as a percentage of annual emissions.

\section{Categories of Reductions}

The Voluntary Reporting Program classifies emissions reductions as direct and indirect and quantifies them by comparison with a "basic" or "modified" reference case. Direct emissions reductions are attributable to equipment owned or leased by the reporter. Direct reductions are further subdivided by source into emissions reductions from stationary combustion, from transportation or other mobile sources, and from other direct sources. Indirect reductions are attributable to some action of the reporter that reduces emissions from another source. When GM raised the fuel efficiency of GM-built vehicles, the vehicle owners experienced direct reductions, and GM experienced an indirect reduction.
For electric: utilities, the most important category of indirect emissions is wholesale power transactions. Utilities chose various methods for reporting on the emissions consequences of their wholesale purchases and sales of electricity. When utilities buy bulk electricity, they can be viewed as "causing" the seller to create additional emissions, while possibly reducing the utilities' own emissions. On the other hand, selling bulk electricity can cause increased direct emissions but may reduce emissions on the part of the buyer.

For reporting purposes, the form defines total indirect reductions as the sum of the change in wholesale power purchases, less the change in wholesale power sales, plus other indirect reductions. Total reductions (direct plus indirect) consist of direct reductions, reductions in wholesale power purchases, and other indirect reductions. Power sales are not included in the total, because the emissions and reductions associated with power market sales will, in principle, have already been picked up as direct emissions and direct reductions associated with power generation.

Sequestration has an effect similar to a reduction, but differs in kind. Sequestration is defined as the removal of carbon dioxide from the atmosphere, almost always in the form of carbon extracted from the air by trees or other plants and converted, through photosynthesis, into biomass. Entity-level sequestration is reported as the volume of atmospheric carbon dioxide sequestered. In the accounting for entity-level emissions and reductions, the form treats sequestration as neither a direct nor an inclirect reduction, but as a separate line item that is included in total reductions.

\section{Case Study: Detroit Edison}

Detroit Edison is a large, investor-owned utility that supplies electricity to the urban areas of lower Michigan. Much of the power produced from its generators is fossil-fueled, but it also operates a large nuclear unit, Fermi, and has access to hydroelectric power. In the course of a typical year, Detroit Edison also buys and sells wholesale power, usually selling more than it buys. While it reported various projects to reduce its emissions, the largest reported contribution to carbon dioxide reductions came from improvements to the operational efficiency of the Fermi nuclear unit. When this unit is functioning it produces large amounts of power without emitting greenhouse gases. In 1994, when an equipment failure kept the nuclear unit out of operation for the entire year, Detroit Edison's progress in reducing its emissions was suddenly reversed. The company made up the shortfall by increasing generation from its other fossil-fueled plants, by reducing power sales, and by increasing power purchases. 
Detroit Edison computed its entity-level emissions using a basic reference case: its reductions in greenhouse gas emissions were calculated in comparison with its 1990 emissions. Table 7 shows Detroit Edison's report of its entity-level emissions for 1990-1994 and its reductions since 1991. Total indirect emissions are defined as emissions from purchased power plus "other indirect emissions." Because the utility reported no "other indirect emissions," indirect emissions comprised only emissions from purchased power.

In 1994, Detroit Edison's total emissions rose above the reference year for the first time. Using the basic reference case, Detroit Edison reported 3 years of emissions reductions and an emissions increase for 1994. This pattern was the same for reported direct and indirect emissions.

\section{Case Study: General Motors}

The report filed by GM showed a company-wide effort to eliminate the use of ozone-depleting chemicals. As part of its entity-wide report, GM attached supplemental information demonstrating substantial reductions in the emissions of halogenated substances and other chemical compounds with large heat-trapping capacities. Although it did not report emissions reductions per se, GM's emissions of nine separate chemicals declined between 1987 and 1994. The chemicals and the reductions achieved relative to 1987 emissions levels are shown in Table 8. In total, the net reported reductions are equivalent to more than 17 million metric tons of carbon dioxide.

The reduction in emissions of $\mathrm{CFC}-12-1,500$ metric tons-is particularly notable. All but 18 metric tons of the reduction is attributable to the elimination of CFC-12 in automobile air conditioners installed in new
$G M$ vehicles. GM estimates that about 10 percent of the coolant charge in automobile air conditioners leaks annually for 10 years after purchase. Thus, over time, GM's estimated indirect emissions of CFC-12 will continue to decline until they reach zero around 2004.

Table 8. Changes in 1994 Emissions of Halogenated Substances and Minor Gases Reported by General Motors Relative to 1987 Levels (Metric Tons)

\begin{tabular}{|c|c|c|}
\hline \multirow[b]{2}{*}{ Gas } & \multicolumn{2}{|c|}{ Change in Emissions } \\
\hline & $\begin{array}{l}\text { Amount } \\
\text { of Gas }\end{array}$ & $\begin{array}{c}\text { GWP. } \\
\text { Weighted }\end{array}$ \\
\hline CFC-11 $\ldots \ldots \ldots \ldots \ldots$ & 1 & 5,443 \\
\hline CFC-12 (Direct) $\ldots \ldots \ldots$ & -18 & $-150,361$ \\
\hline CFC-12 (Indirect) $\ldots \ldots \ldots$ & $-1,478$ & $-12,562,038$ \\
\hline CFC-113 $\ldots$ & -996 & $-4,981,460$ \\
\hline CFC-114 $\ldots \ldots$ & -1 & $-12,655$ \\
\hline HCFC-22 $\ldots \ldots \ldots \ldots \ldots$ & -7 & $-11,566$ \\
\hline HCFC-141b $\ldots \ldots \ldots \ldots$ & 10 & 6,287 \\
\hline HFC-134a (Indirect) $\ldots \ldots$ & 557 & 724,694 \\
\hline HFC-152a & - & -64 \\
\hline Carbon Tetrachloride . . . . . . & -10 & $-14,605$ \\
\hline Methyl Chloroform ........ & $-2,099$ & $-230,848$ \\
\hline Methylene Chloride ...... & $-1,164$ & $-10,479$ \\
\hline Total $\ldots . . . \ldots \ldots \ldots$ & - & $-17,237,651$ \\
\hline
\end{tabular}

"Less than 0.5 metric tons.

Note: For all chemical compounds except CFC-12, emissions are from stationary sources.

Source: Energy Information Administration, Form ElA1605, "Voluntary Reporting of Greenhouse Gases" (1995 reporting cycle).

Table 7. Summary of Detroit Edison's Entity-Level Emissions Report

(Thousand Metric Tons of Carbon Dioxide)

\begin{tabular}{|c|c|c|c|c|c|}
\hline Accounting Category & 1990 & 1991 & 1992 & 1993 & 1994 \\
\hline \multicolumn{6}{|l|}{ Emissions } \\
\hline Direct (Stationary Combustion) & 39,637 & 39,570 & 36,178 & 38,551 & 42,125 \\
\hline Indirect (Purchased Power) & 5,696 & 1,429 & 1,348 & 2,087 & 6,065 \\
\hline Total Emissions $\ldots \ldots \ldots$ & 45,333 & 40,998 & 37,526 & 40,638 & 48,191 \\
\hline Emissions from Power Sales ..... & 11,006 & 5,161 & 3,003 & 3,411 & 1,866 \\
\hline \multicolumn{6}{|l|}{ Emissions Reductions } \\
\hline Direct (Stationary Combustion) & NA & 67 & 3,460 & 1,086 & $-2,488$ \\
\hline Indirect (Purchased Power) . . . . . . . & NA & 4,267 & 4,348 & 3,609 & -370 \\
\hline Total Reductions $\ldots \ldots \ldots \ldots \ldots$ & NA & 4,334 & 7,807 & 4,695 & $-2,858$ \\
\hline Reductions as Percentage of Emissions .... . & NA & $10.6 \%$ & $20.8 \%$ & $11.6 \%$ & $-5.9 \%$ \\
\hline
\end{tabular}

NA $=$ not applicable.

Notes: Detroit Edison uses a basic reference case keyed to 1990. Reductions are defined as the difference between 1990 emissions and current emissions. Totals may not equal sum of components due to independent rounding.

Source: Energy Information Administration, Form EIA-1605, "Voluntary Reporting of Greenhouse Gases" (1995 reporting cycle). 
Because HFC-134a is used as a substitute for CFC-12 in automobile air conditioners, GM's decreased emissions of CFC-12 are partially offset by increased emissions of HFC-134a: between 1987 and 1994, emissions of HFC-134a from GM manufactured vehicles grew by 557 metric tons. However, the global warming potential of HFC-134a is currently estimated to be less than onesixth that of CFC-12, before taking into account the yetto-be-determined cooling effects of CFC-12's ozonedepleting characteristics.?

\section{Reductions Compared by Type of Reference Case}

Most entity-wide reporters reported emissions reductions. Reporters calculated their emissions reductions by comparing current emissions with either a "basic reference case" or a "modified reference case." A basic reference case is defined as a reporter's emissions in some base year (usually 1990) or average of base years (for example, the average for 1987-1990). A modified reference case is defined as an estimate of what the reporter's emissions would have been in the absence of some set of actions taken by the reporter. A reduction is then the difference between the reporter's actual emissions and the emissions in the reporter's reference case.

Ten reporters (including 9 electric utilities) adopted a basic reference case, reporting that measured emissions had declined from previous years. About 25 reporters adopted a modified reference case, indicating that emissions were lower than they might have been in the absence of reduction actions taken by the reporter. Several reporters did not report reductions or did not specify a type of reference case. Several reporters used hybrid reference cases, using a basic reference case to define their reductions of carbon dioxide from stationary combustion, while using a modified reference case for carbon sequestration or reductions associated with other gases.

The largest reductions in carbon dioxide emissions were reported by companies using a modified reference case, including Florida Power \& Light (20.4 million metric tons in 1994), Duke Power (10 million metric tons) and the Tennessee Valley Authority $(7.7$ million metric tons). The largest reductions reported by companies using a basic reference case were Niagara Mohawk Power Corporation (3.7 million metric tons in 1994) and Public Service Electricity \& Gas (3.5 million metric tons).
Table 9 illustrates reported reductions by type of reference case and also categorizes reductions as direct or indirect. The bulk of the direct reductions reported were accounted for by reductions in emissions from stationary combustion. Reported transportation emissions reductions (direct and indirect) accounted for less than 200,000 metric tons of carbon dioxide in 1994.

Almost all of the indirect emissions reductions claimed by basic reference case reporters were attributed to reductions in emissions from purchased power. In contrast, reporters using a modified reference case indicated that changes in emissions from purchased power actually increased (rather than reduced) emissions.

Emissions from wholesale power sales, which were reported only by reporters using a basic reference case, also indicated an increase (rather than a reduction) in emissions. Most of the emissions increase was accounted for by Detroit Edison's reported decline in wholesale sales. Only four reporters actually reported reductions (or offsetting increases) in wholesale power sales. Some reporters may have netted their power sales in the "purchased power" line on the form to produce their preferred definition of total emissions reductions. Table 9 shows emissions reductions both including and excluding emission reductions from wholesale power sales.

Most emissions reductions of other gases were computed on the basis of a modified reference case, and reductions were dominated by indirect methane reductions reported by the New England Electric System $(620,000$ metric tons carbon dioxide equivalent) and direct methane emissions reductions reported by Cinergy (440,000 metric tons carbon dioxide equivalent). Both sets of reductions were probably due to the effects of landfill gas operations. Florida Power \& Light reported a direct emissions reduction (based on a modified reference case) of 5 metric tons of sulfur hexafluoride. However, since this chemical has a global warming potential of 24,900 , the reported reduction is equivalent to about 125,000 metric tons of carbon dioxide.

\section{Future Reduction Commitments Made Under Schedule IV}

Schedule IV asks reporters to record present and future commitments, both at an entity level and a project lèvel, to future greenhouse gas emissions reductions. This section of the form is intended to be useful to various

${ }^{7}$ D.L. Albritton et al., "Trace Gas Radiative Forcing Indices," in J.T. Houghton et al., Climate Change 1994 (Cambridge University Press, 1995), p. 222. 
Table 9. Reported Entity-Level Emissions Reductions by Type of Reference Case, 1991-1994 (Thousand Metric Tons Carbon Dioxide Equivalent)

\begin{tabular}{|c|c|c|c|c|}
\hline Reductions by Type of Reference Case & 1991 & 1992 & 1993 & 1994 \\
\hline \multicolumn{5}{|l|}{ Basic Reference Case } \\
\hline Direct Reductions ... & 10,819 & 20,713 & 25,249 & 22,588 \\
\hline Indirect Reductions . . . . . . . . . . & 2,648 & 736 & 4,763 & 1,690 \\
\hline Total, Basic Reference Case . . . . . . & 13,467 & 21,449 & 30,012 & 24,278 \\
\hline Emissions from Power Sales ......... & 6,888 & 9,716 & 9,567 & 10,381 \\
\hline $\begin{array}{l}\text { Total Emissions, Basic Reference Case } \\
\text { (Net of Power Sales) . . . . . . . . . }\end{array}$ & 6,579 & 11,733 & 20,445 & 13,897 \\
\hline \multicolumn{5}{|l|}{ Modified Reference Case } \\
\hline Carbon Dioxide.... & 18,043 & 22,591 & 26,579 & 37,202 \\
\hline 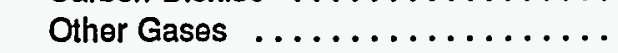 & 441 & 685 & 757 & 764 \\
\hline $\begin{array}{l}\text { Total Direct Reductions } \ldots \ldots \ldots \\
\text { Indirect Reductions }\end{array}$ & 18,485 & 23,276 & 27,336 & 37,966 \\
\hline Carbon Dioxide ... & 236 & 55 & 383 & 963 \\
\hline Other Gases $\ldots \ldots \ldots \ldots \ldots \ldots$ & 362 & 549 & 718 & 743 \\
\hline Total Indirect Reductions . . . . . . . & 598 & 604 & 1,100 & 1,706 \\
\hline $\begin{array}{l}\text { Total Emissions, } \\
\text { Modified Reference Case .......... }\end{array}$ & 19,082 & 23,879 & 28,436 & 39,671 \\
\hline Carbon Sequestration ............ & 74 & 390 & 418 & 453 \\
\hline
\end{tabular}

Notes: Emissions of other gases computed on the basis of 100-year integration global warming potentials. Aggregations of estimated emissions and reductions across reporters should be used with caution, since reporters may not calculate emissions and reductions in the same way, and multiple reporters may report on some of the same activities. Excludes data claimed as "confidential" by reporters. Totals may not equal sum of components due to independent rounding.

Source: Energy Information Administration, Form ElA-1605, "Voluntary Reporting of Greenhouse Gases" (1995 reporting cycle). .

voluntary program as a mechanism for collating reduction pledges. In the first reporting year, only electric utility Climate Challenge participants availed themselves of this opportunity.

Schedule IV requests information on the horizon year (the year when the commitment is expected to be met), the associated voluntary program, the type of reference case, and the greenhouse gas involved and amount of reduction pledged for that gas. In Section 2, reporters are asked about financial commitments. This section requires information on the type and amount of expenditure, when it will be made, the associated voluntary program, and the amount of money actually spent in 1994. The third section of Schedule IV asks for projectlevel information on both existing and future projects. Most reporters did not quantify either specific reduction commitments or spending targets. Of the 108 reporters, 26 made a total of 42 entity commitments; 21 reporters made a total of 44 financial commitments; and 29 reporters listed a total of 232 project-level commitments.
Many of the entity-level commitments reported were reiterations of the substantive targets already stated in Climate Challenge accords with DOE. ${ }^{8}$ While the absolute amount of the entity-level commitments varied widely, a notably large commitment was made by the Tennessee Valley Authority, which pledged to reduce carbon dioxide emissions by 22.7 million short tons below its modified reference case by the horizon year 2000.

Many of the financial commitments made by reporters concerned amounts pledged to join particular utility industry forestry management programs. The single largest reported financial commitment made was Allegheny Power Service Corporation's pledge to spend $\$ 62.8$ million on demand side management programs. Some reporters used the third section on projects to summarize their Schedule II projects, while others listed new projects they planned to implement or projects that they had started but which had not yet produced quantifiable reductions.

'Interested readers with Internet access can find details about the Climate Challenge program and the full text of individual utilities' Climate Challenge accords on the world wide web at http://beijing.dis.anl.goo/ee-cgi-bin/ccac.pl. 
. 


\section{Summary and Case Studies of Reported Projects}

\section{Background}

This chapter examines the individual greenhouse gas emissions reduction and carbon sequestration projects reported on Schedule II of Form EIA-1605 and on Form EIA-1605EZ. Reporting project-level information can promote social learning. Dissemination of the information reported on projects compiled in the database may make other individuals and organizations engaged in similar activities more aware of actions that could achieve emissions reductions or sequester carbon. Many of the reported actions have broad applicability and, if widely adopted, could make a significant contribution to controlling atmospheric levels of greenhouse gases.

Project-level reporting differs from entity-level reporting in that it focuses on the achievements of specific measures undertaken to reduce emissions or increase sequestration. Although a project that reduces emissions or sequesters carbon may involve one or more well-defined actions, the net effect of those actions on atmospheric levels of greenhouse gases may be difficult to calculate. For example, an electric utility that closes an old, inefficient power plant can determine quite ac- curately the change in emissions resulting from the closure. However, if there is no corresponding reduction in customer demand for electricity, the utility will have to increase generation at its other plants or purchase power from other generators. The utility cannot always determine the sources of replacement power and, therefore, cannot easily estimate the emissions consequences of the plant closing with complete certainty.

Despite the difficulty in evaluating the net effects of individual projects on greenhouse gas emissions and carbon sequestration, the project-level activities reported should provide emissions reductions or increases in carbon sequestration relative to the projected levels of emissions or sequestration that would have occurred had the activities in question not been conducted.

\section{Overview of Projects Reported}

Of the 108 reporters, 99 provided information on a total of 645 projects (Table 10). Nine reporters did not submit project data but provided only entity-wide reports and/or future commitments. The 64 reporters using the

Table 10. Summary of Reported Emissions Reduction and Carbon Sequestration Projects by Project Type

\begin{tabular}{|c|c|c|c|c|c|c|}
\hline \multirow[b]{2}{*}{ Type of Project } & \multicolumn{2}{|c|}{ Reported on Long Form } & \multicolumn{2}{|c|}{ Reported on Short Form } & \multicolumn{2}{|c|}{ Total } \\
\hline & $\begin{array}{l}\text { Number of } \\
\text { Reporters }\end{array}$ & $\begin{array}{l}\text { Number of } \\
\text { Projects }\end{array}$ & $\begin{array}{l}\text { Number of } \\
\text { Reporters }\end{array}$ & $\begin{array}{l}\text { Number of } \\
\text { Projects }\end{array}$ & $\begin{array}{l}\text { Number of } \\
\text { Reporters }\end{array}$ & $\begin{array}{l}\text { Number of } \\
\text { Projects }\end{array}$ \\
\hline $\begin{array}{l}\text { Electricity Generation, Transmission, } \\
\text { and Distribution ............. }\end{array}$ & 49 & 188 & 23 & 36 & 66 & 224 \\
\hline Cogeneration $^{\mathrm{a}}$ & 5 & 7 & 0 & 0 & 5 & 7 \\
\hline Energy End Use $\ldots \ldots \ldots \ldots \ldots$ & 52 & 160 & 25 & 47 & 74 & 207 \\
\hline Transportation $\ldots \ldots \ldots \ldots \ldots$ & 21 & 26 & 5 & 7 & 26 & 33 \\
\hline Methane Recovery $\ldots \ldots \ldots \ldots$ & 18 & 28 & 2 & 15 & 20 & 43 \\
\hline Carbon Sequestration ......... & 23 & 58 & 17 & 20 & 40 & 78 \\
\hline Halogenated Substances . . . . . . . & 12 & 13 & 1 & 2 & 13 & 15 \\
\hline Other Projects $\ldots \ldots \ldots \ldots \ldots$ & 29 & 34 & 4 & 4 & 33 & 38 \\
\hline $\operatorname{Total}^{b} \ldots \ldots \ldots \ldots \ldots \ldots$ & 64 & 514 & 35 & 131 & 99 & 645 \\
\hline
\end{tabular}

a Includes projects for which confidentiality was requested.

${ }^{b}$ The total numbers of reporters are smaller than the sums of the numbers of reporters for each project type, because most reporters provided information on more than one project.

Source: Energy Information Administration, Forms EIA-1605 and EIA-1605EZ, "Voluntary Reporting of Greenhouse Gases" (1995 reporting cycle). 
long form submitted information on 514 projects, representing 80 percent of all the projects. The remaining 131 projects were reported on the short form.

While 87 of the 99 entities reporting projects were electric utilities, two-thirds ( 69 percent) of the projects reported involve either electricity supply or energy end use. The other one-third involved diverse reduction measures, many of which are applicable to nonutilities. The following projects are examples of this diversity:

- Generating electricity from landfill gas and displacing emissions from conventional power sources

- Urban forestry or planting trees to sequester carbon and, if adjacent to buildings, reducing emissions associated with heating and air conditioning

- Suppressing anode effects during aluminum production to reduce emissions of the halogenated substances perfluoromethane and perfluoroethane

- Video conferencing to reduce emissions associated with vehicle travel required to assemble employees from several locations for business meetings
- Recycling or reusing materials (such as coal ash, paper, aluminum, iron, steel, and glass), resulting in lower life-cycle emissions relative to the use of virgin materials.

Because of the high proportion of electric utilities reporting, over 78 percent of the total reductions reported at the project level were for electricity supply and energy end use projects (Table 11).

The greatest reductions in emissions during 1994 were achieved by electricity supply and energy end use projects, although the size of reductions varies considerably. The largest emissions reduction projects reported involve improving the availability of nuclear power plants. By displacing power generated by coal, individual availability improvement projects have achieved annual reductions in carbon dioxide emissions in excess of 10 million metric tons. Utility demand-side management programs also tend to yield large reductions, because they typically encompass a wide range of activities affecting large numbers of utility customers.

Table 11. Summary of Project-Level Emissions Reductions and Ciarbon Sequestration (Metric Tons)

\begin{tabular}{|c|c|c|c|c|c|c|c|}
\hline \multirow[b]{2}{*}{ Type of Project } & \multicolumn{7}{|c|}{ Reductions or Sequestration Reported for 1994} \\
\hline & $\begin{array}{l}\text { Carbon } \\
\text { Dioxide }\end{array}$ & Methane & $\begin{array}{l}\text { Nitrous } \\
\text { Oxide }\end{array}$ & CFCs & PFCs & $\begin{array}{l}\text { Other } \\
\text { Gases }\end{array}$ & $\begin{array}{l}\text { Carbon Dioxide } \\
\text { Equivalent }^{\mathrm{a}}\end{array}$ \\
\hline $\begin{array}{l}\text { Electricity Generation, Transmișsion, } \\
\text { and Distribution . . . . . . . . }\end{array}$ & $50,306,364$ & 4,074 & 934 & 0 & 0 & 0 & $50,705,103$ \\
\hline Cogeneration ${ }^{\mathbf{b}}$ & 246,970 & 0 & 0 & 0 & 0 & 0 & 246,970 \\
\hline Energy End Use $\ldots \ldots \ldots \ldots \ldots$ & $11,703,467$ & 1,406 & 218 & 0 & 0 & 0 & $11,807,543$ \\
\hline Transportation .... & 22,146 & 3 & 3 & 0 & 0 & 0 & 23,091 \\
\hline Methane Recovery $\ldots \ldots \ldots \ldots$ & 195,769 & 143,918 & 0 & 0 & 0 & 0 & $3,721,751$ \\
\hline Carbon Sequestration ......... & 772,130 & 0 & 0 & 0 & 0 & 0 & 772,130 \\
\hline Halogenated Substances . . . . . . . & 0 & 0 & 0 & 11 & 484 & 8 & $3,955,480$ \\
\hline Other Projects $\ldots \ldots \ldots \ldots \ldots$ & $2,649,503$ & 2,844 & 0 & 0 & 0 & 0 & $2,719,183$ \\
\hline Total $^{c} \ldots \ldots \ldots \ldots \ldots \ldots$ & $65,896,349$ & 152,245 & 1,155 & 11 & 484 & 8 & $73,951,254$ \\
\hline
\end{tabular}

${ }^{a}$ Carbon dioxide equivalents were calculated using the 100-year global warming potentials for methane, nitrous oxide, and halogenated substances reported by D.L. Albritton et al., "Trace Gas Radiative Forcing Indices," in J.T. Houghton et al., Climate Change 1994 (Cambridge, UK: Cambridge University Press, 1995), p. 222.

bExcludes projects for which confidentiality was requested.

'Totals include all emissions reductions reported. No attempt has been made to correct for double counting, where more than one entity has (or may have) reported on the same emissions reduction project.

Notes: "CFCs" (chlorofluorocarbons) include 9 metric tons of CFC-12 and 2 metric tons of CFC-11. "PFCs" (perfluorocarbons) include 466 metric tons of perfluoromethane $\left(\mathrm{CF}_{4}\right)$ and 17 metric tons of perfluoroethane $\left(\mathrm{C}_{2} \mathrm{~F}_{6}\right)$. "Other Gases" include $\mathrm{HCFC}-22$, HCFC-123, HFC-134a, halon 1301, sulfur hexafluoride (3 metric tons), and methyl chloroform (4 metric tons). Aggregations of estimated emissions and reductions across reporters should be used with caution, since reporters may not calculate emissions and reductions in the same way, and multiple reporters may report on some of the same activities.

Source: Energy Information Administration, Forms EIA-1605 and EIA-1605EZ, "Voluntary Reporting of Greenhouse Gases" (1995 reporting cycle). 
The relative size of the emissions reductions or carbon sequestration achieved by projects varies dramatically (Figure 2). Halogenated substances projects reported have the highest average emissions reduction (measured in carbon dioxide equivalent) because of the high global warming potentials of the gases involved.

\section{Figure 2. Average 1994 Emissions Reduction or Carbon Sequestration Achleved per Project by Project Type}

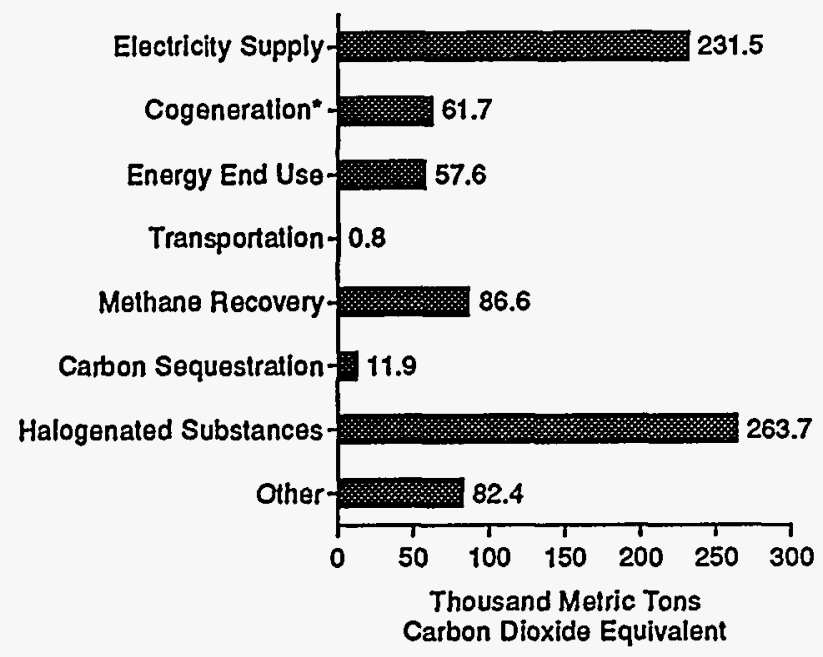

-Excludes projects for which confidentiality was requested.

Source: Energy Information Administration, Forms ElA-1605 and ElA-1605EZ, "Voluntary Reporting of Greenhouse Gases" (1995 reporting cycle).

The geographic distribution of projects is summarized in Figure 3, which shows that the emissions reduction and sequestration activities reported were concentrated in the East and North Central regions of the United States. Nine projects were located in foreign countries.

Sixteen voluntary programs are represented in the projects reported (Table 12). Most of the projects ( 86 percent) are affiliated with Climate Challenge. Furthermore, the electric utility industry strongly supports voluntary initiatives for controlling greenhouse gas emissions and has encouraged reporting among its members. Other voluntary programs are not as well represented because many were still being organized in 1994, the latest year for which project achievements could be reported in the 1995 reporting cycle.
Table 12. Affiliation of Reported Projects with Voluntary Programs

\begin{tabular}{|c|c|c|}
\hline Voluntary Program & Reporters & Projects \\
\hline Climate Challenge . . . . . . . . & 78 & 560 \\
\hline Green Lights . . . . . . . . . . & 12 & 15 \\
\hline Landfill Methane Outreach . . . . . & 4 & 6 \\
\hline Natural Gas Star . . . . . . . . . . & 3 & 7 \\
\hline Energy Star Computers . . . . . . . & 2 & 2 \\
\hline $\begin{array}{l}\text { U.S. Initiative on Joint } \\
\text { Implementation } \ldots \ldots \ldots \ldots \ldots\end{array}$ & 2 & 2 \\
\hline $\begin{array}{l}\text { Voluntary Aluminum Industrial } \\
\text { Partnership ... . . . . . . . }\end{array}$ & 2 & 2 \\
\hline Coalbed Methane Outreach .... & 1 & 1 \\
\hline Energy Star Buildings . . . . . . & 1 & 1 \\
\hline Energy Star Transformers . . . . . & 1 & 1 \\
\hline Waste Wise . . . . . . . . . . & 1 & 1 \\
\hline Other $\ldots \ldots \ldots \ldots \ldots \ldots$ & 6 & 7 \\
\hline None $\ldots \ldots \ldots \ldots \ldots \ldots$ & 10 & 41 \\
\hline Total $^{a} \ldots \ldots \ldots$ & 99 & 645 \\
\hline
\end{tabular}

The total number of reporters is smaller than the sum of the numbers of reporters for each program, because most reporters provided information on more than one project.

Source: Energy Information Administration, Forms EIA1605 and ElA-1605EZ, "Voluntary Reporting of Greenhouse Gases" (1995 reporting cycle).

\section{Electricity Supply}

\section{Background}

The electric utility sector produces more than 490 million metric tons of carbon dioxide per year-about one-third of total U.S. carbon dioxide emissions. Between 1990 and 1994, carbon dioxide emissions from this sector increased at an annual rate of 1 percent. This trend reflects U.S. economic growth and corresponding increases in energy consumption. However, electric utility carbon dioxide emissions grew at a slower rate than energy consumption (1.3 percent per year), which in turn grew at a slower rate than the U.S. economy (2 percent per year). Factors that helped to slow the growth in emissions include increased reliance on natural-gas-fired and nuclear power plants and efficiency improvements in both the generation and utilization of electricity.'

'Energy Information Administration, Emissions of Greenhouse Gases in the United States 1987-1994, DOE/EIA-0573(87-94) (Washington, DC, October 1995), pp. 12-13. 
Figure 3. Geographic Location of Projects

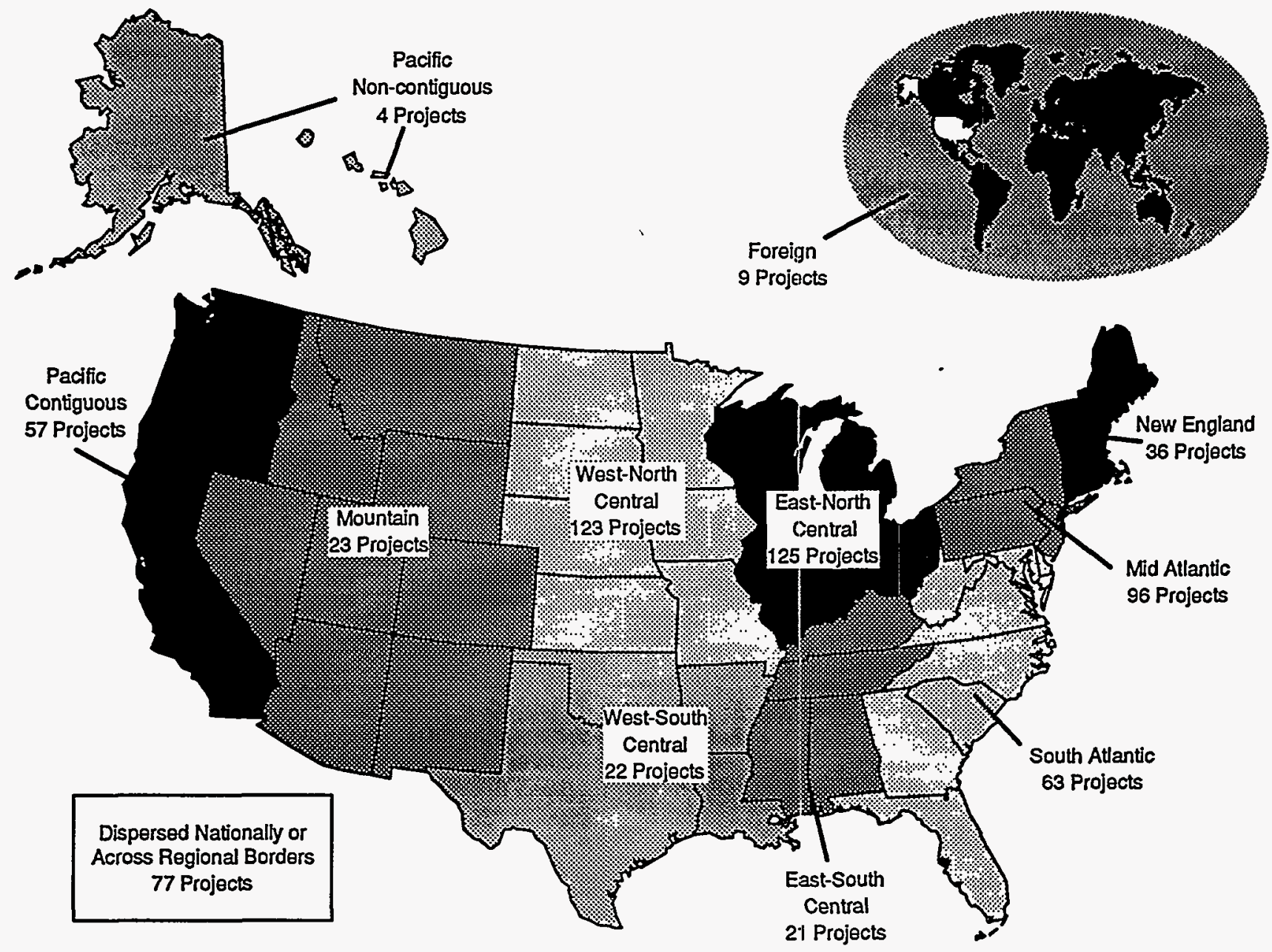

Source: Energy Information Administration, Forms EIA-1605 and EIA-1605EZ, “Voluntary Reporting of Greenhouse Gases” (1995 reporting cycle).

The President's Climate Change Action Plan identifies nine specific action items aimed at reducing supply-side greenhouse gas emissions from the electric utility sector. These action items are designed to increase natural gas utilization, enhance the commercialization of renewable technologies, improve the performance of hydroelectric generating stations, and improve the efficiency of electricity transmission and distribution systems. ${ }^{10}$

The cornerstone of the Climate Change Action Plan, for electric utilities, is the Climate Challenge program. Administered by the U.S. Department of Energy (DOE),
Climate Challenge is a voluntary program in which electric utilities enter into formal agreements with the DOE that spell out their commitments to reduce greenhouse gas emissions. The contents of these formal accords vary from utility to utility, but they may, for example, include commitments to stabilize greenhouse gas emissions at or below 1990 levels, as well as commitments to undertake specific greenhouse gas reduction projects. Climate Challenge participants are encouraged to report their reduction activities to the EIA. The Climate Challenge program is designed to provide individual utilities flexibility in identifying and pursuing the most cost-effective approaches to green-

${ }^{10}$ President WilliamJ. Clinton, The Climate Change Action Plan (Washington, DC, October 1993), Summary Table of Actions, Actions $23-31$. 
house gas reductions. ${ }^{11}$ There are currently more than 100 participants in the Climate Challenge program, representing over 60 percent of total U.S. electric generating capacity. The vast majority of the electricity supply projects reported to the EIA ( 91 percent of the total) were undertaken in part in fulfillment of the reporters' Climate Challenge commitments.

\section{Projects Reported}

Opportunities for achieving significant, cost-effective emissions reductions within the electric power industry are numerous, as shown by the large number of electricity supply projects reported: 224 such projects were reported, accounting for more than one-third of all projects reported under the Voluntary Reporting Program. Not only are electricity supply projects the most numerous reported, they are the largest as well. In 1994, half of all reported electricity supply projects generated carbon dioxide reductions in excess of 10,000 metric tons each. Of the 13 largest projects reported (yielding more than 1 million metric tons of carbon dioxide reductions in 1994), 11 were electricity supply projects (Figure 4).

Electricity supply projects fall into two main categories: (1) generation, involving improvements in the conversion of fossil fuels and other energy sources into elec-

\section{Figure 4. Electricity Emissions Reduction Projects by Project Size}

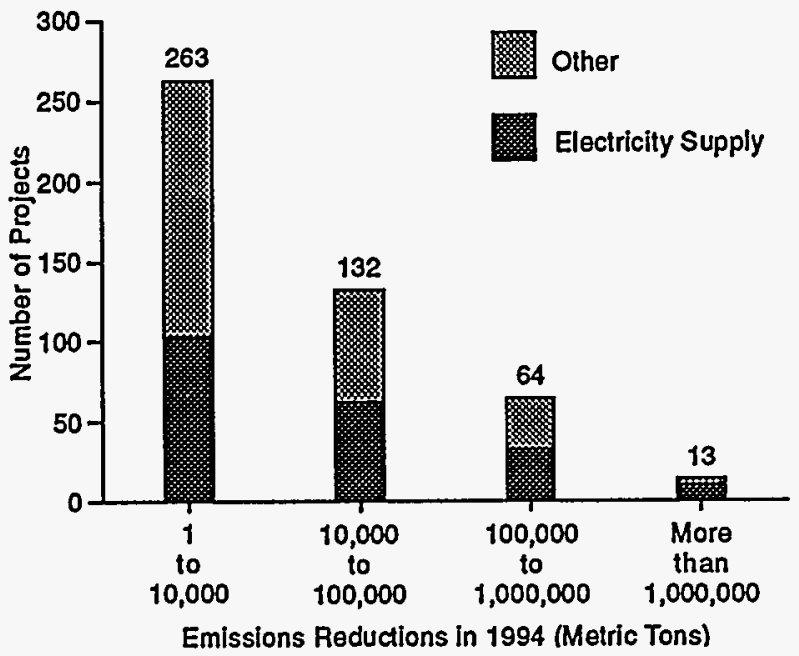

Note: Includes only nonconfidential projects for which carbon dioxide emissions reductions in 1994 were reported.

Source: Energy Information Administration, Forms EIA-1605 and ElA-1605EZ, "Voluntary Reporting of Greenhouse Gases" (1995 reporting cycle). tricity, and (2) transmission and distribution, involving improvements in the delivery of electricity from the power plant to the end user. In terms of both number and size, generation projects significantly outweigh transmission and distribution projects (Figure 5).

\section{Figure 5. Electricity Emissions Reduction Projects by Project Type}

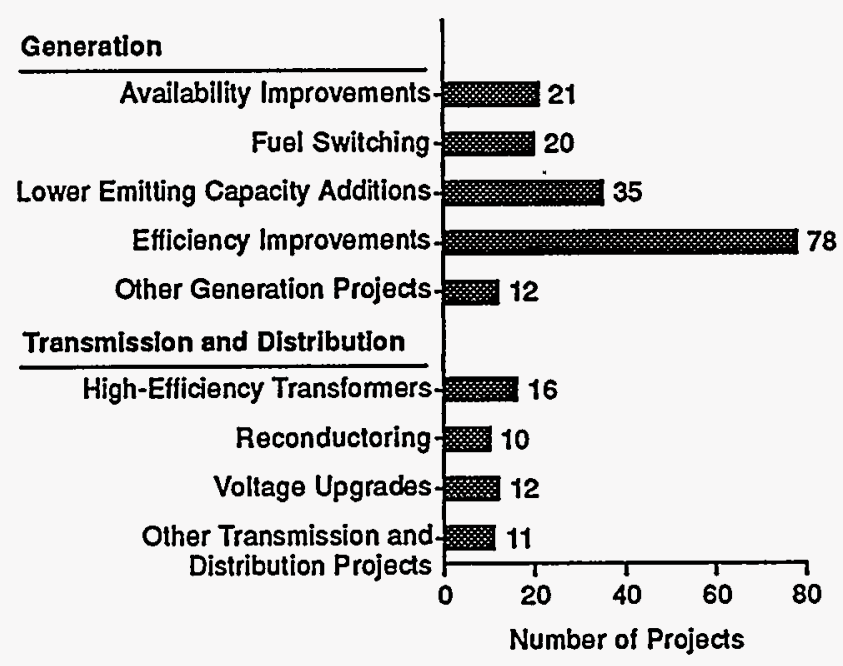

Notes: Excludes 36 electricity supply projects reported on Form EIA1605EZ. Some projects may be counted in more than one category.

Source: Energy Information Administration, Form ElA-1605, Voluntary Reporting of Greenhouse Gases" (1995 reporting cycle).

\section{Generation Projects}

Availability Improvements. A significant fact emerging from the first-year data is the importance of power plant availability improvements as a means of reducing carbon dioxide emissions. These projects are not numerous-only 21 availability improvement projects were reported (Figure 5). ${ }^{12}$ But their number belies the impact that availability improvements have on carbon dioxide emissions. On average, availability improvements reduced carbon dioxide emissions by more than 2 million metric tons per project in 1994.

Availability improvement projects primarily reflect developments within the nuclear power industry. Of the 21 availability improvement projects reported, 12 occurred at nuclear power plants. Mainly through significant advances in operating, maintenance, and refueling procedures, capacity factors at nuclear plants were increased, displacing fossil-based power generation. Examples of the specific types of changes leading to capacity factor improvements include:

\footnotetext{
${ }^{11}$ President William J. Clinton, The Climate Change Action Plan (Washington, DC, October 1993), Foundation Actions, Launch the Climate Challenge.

${ }^{12}$ Including 12 projects that combined availability improvements with other actions, such as efficiency improvements.
} 


\section{Generation Projects: Definitions and Terminology}

The purpose of the electricity generation process is to convert other forms of energy (e.g., heat) into electrical energy. During this process, the combustion of fossil fuels to produce heat causes greenhouse gas emissions. In addition to substantial releases of carbon dioxide, fossil fuel combustion also results in the emission of small quantities of methane and nitrous oxide. Generation projects reduce greenhouse gas emissions either by reducing the quantity of fossil fuel used in the generation process or by replacing higher emitting fuels (such as coal) with cleaner burning fuels (such as natural gas).

Efficiency Improvements. By increasing the efficiency of the generation process, efficiency improvement projects at fossil-fuel-fired power plants reduce the plants' heat rate, defined as the amount of fossil energy (measured in British thermal units, or Btu) needed to produce each kilowatthour of electricity. The result is a reduction in the amount of fuel that must be burned to meet generation requirements, and hence a reduction in carbon dioxide (and other greenhouse gas) emissions. Efficiency improvements at nonfossil power plants (e.g., hydroelectric plants) can also reduce greenhouse gas emissions. Emissions reductions occur if the efficiency improvement leads to an increase in the amount of electricity generated by the affected plant, with a consequent reduction in the amount of electricity that must be generated by other (fossil-fuel) plants to meet demand. The displaced generation must be from a fossil plant(s) for emissions reductions to occur.
Availability Improvements. By reducing the frequency and length of planned and unplanned power plant outages, availability improvement projects result in increased utilization of the affected plant. If the resulting increased generation from the plant displaces generation that otherwise would have been produced by a higher emitting plant, emissions reductions will result. Power plant availability is measured by the plant's.capacity factor, defined as therratio of the average load on the plant over a given period to its total capacity. For example, if a 100-megawatt plant operates (on average) at 50 percent of capacity (i.e., at a load of 50 megawatts) over a period of a year, the plant's capacity factor is 50 percent.

Fuel Switching. The amount of carbon contained in fossil fuels and released in the form of carbon dioxide during combustion varies, depending on the type of fuel. Thus, carbon dioxide emissions from a power plant can be reduced by switching from a higher emitting fuel (such as coal) to a lower emitting fuel (such as natural gas).

Increases in Lower Emitting Capacity. By increasing the capacity of an existing lower emitting plant (e.g., a hydroelectric plant or highly efficient cogeneration plant), or by constructing new lower emitting,generating capacity (e.g., wind turbines), a utility can reduce its reliance, or avoid reliance, on higher emitting plants. The result will be a reduction in greenhouse gas emissions from the displaced plants.
- Certain maintenance activities that once were performed only during outages at the Southern Company's Alvin W. Vogtle nuclear plant are now completed while the plant remains on line.

- General Public Utilities Corporation moved to a 2year refueling cycle and enhanced its Preventive Maintenance and Surveillance programs at the Oyster Creek nuclear plant.

- Through improved outage planning, training, and operations support, Illinois Power Company reduced the frequency and duration of forced and refueling outages at its Clinton nuclear plant.

Fuel Switching. Twenty fuel-switching projects were reported. ${ }^{13}$ Twelve of the 20 projects involved switching from coal to other fuel types (Figure 6). Fuels used in place of (or co-fired with) coal included natural gas, oil, wood waste, and tire-derived fuel. Since coal is the highest emitting fossil fuel, switching from coal to other fuels can have a substantial effect on carbon dioxide emissions. For example, switching from bituminous coal to natural gas will reduce carbon dioxide emissions per unit of energy consumed by approximately 43 percent. While other reported actions-namely, switching from oil to gas-may not lead to reductions of the same magnitude, they too can have a significant impact on emissions. Thus, fuel-switching projects, measured in terms of emissions reductions reported, tend to be larger than most other generation projects.

Increases in Lower Emitting Capacity. Projects involving the construction of new, lower emitting power plants or increases in the capacity of existing lower emitting plants were among the most numerous generation projects reported. A total of 35 such projects

\footnotetext{
${ }^{13}$ Including 2 projects that combined fuel switching with other emissions reduction actions.
} 
Figure 6. Electric Power Generation Fuel-Switching Projects by Project Type

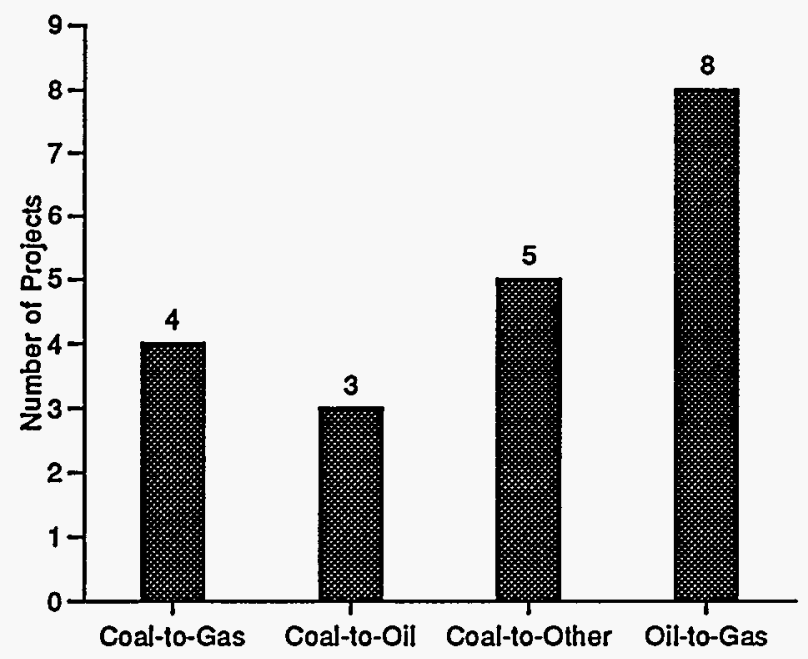

Notes: Excludes 36 electricity supply projects reported on Form EIA$1605 E 2$.

Source: Energy Information Administration, Form ElA-1605, "Voluntary Reporting of Greenhouse Gases" (1995 reporting cycle).

were reported. ${ }^{14}$ The majority involved the installation of new hydropower, renewables, and nuclear capacity, with essentially no greenhouse gas emissions (Figure 7). However, 3 projects involved additional natural-gasfired capacity, and 1 project involved additions to oilfired capacity.

Figure 7. Electric Power Generation Capacity Addition Projects by Energy Source

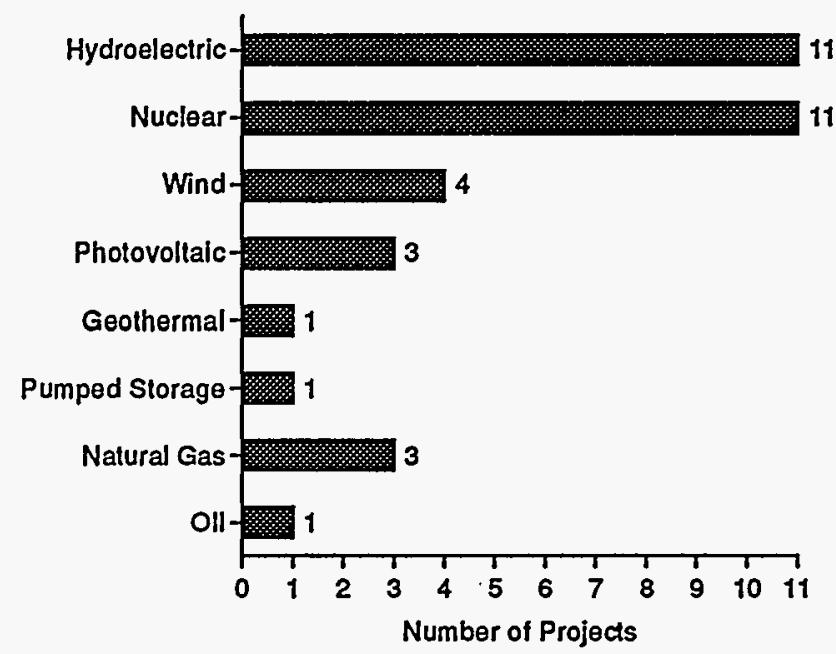

Source: Energy Information Administration, Forms ElA-1605 and EIA-1605EZ, "Voluntary Reporting of Greenhouse Gases" (1995 reporting cycle).
In general, most of these projects were either small additions to existing power plants or the opening of small new plants (primarily renewables plants), and the emissions reductions achieved tended to be small in comparison with those for availability improvement and fuel-switching projects. Some of the larger projects reported included Northern States Power Company's installation of 25 megawatts of wind power near Lake Benton, Minnesota (the largest documented wind resource in Minnesota), and the 100-megawatt uprating of The Southern Company's Alvin W. Vogtle nuclear plant. The Vogtle upgrade was achieved primarily through administrative activities rather than physical modifications to the plant. A license amendment from the Nuclear Regulatory Commission was required for the uprating, which allows The Southern Company to increase the plant's generation.

Efficiency Improvements. Improvements in generating efficiency are the most numerous type of generation project reported (Figure 5). A total of 78 such projects were undertaken. ${ }^{15}$ Heat rate improvements at coalfired power plants are a particularly popular means of increasing efficiency and reducing emissions. The average carbon dioxide emissions reduction per project was smaller for efficiency improvements than for any other type of generation project. There are numerous opportunities for improving efficiency at existing coalfired power plants, but the efficiency gains-and hence reductions in fuel consumption and emissions-are limited by the technology and tend to be small. Even in the context of long-established technologies (e.g., coalfired steam turbine plants) efficiency gains were reported in a wide range of projects. Examples of the types of improvements made, and the magnitude of the resulting efficiency gains, include the following:

- Allegheny Power Service Corporation replaced the boiler control systems at three of its power plants, resulting in a 0.5 -percent improvement in the plants' heat rate.

- Through a combination of equipment upgrades and improved equipment operation and maintenance practices, The Southern Company reduced the average heat rate of its 26 coal-fired power plants from 9,810 Btu per kilowatthour to 9,739 Btu per kilowatthour (a 0.7-percent improvement).

- Wisconsin Power \& Light installed high-efficiency turbine blades at Columbia Unit 1 in 1994; a 1percent improvement in efficiency is expected.

\footnotetext{
${ }^{14}$ Including 13 projects combining increases in lower emitting capacity with other emissions reduction actions.

${ }^{15}$ This total includes 22 "hybrid" projects combining efficiency improvements with other emissions reduction actions, such as availability improvements or increases in lower emitting capacity.
} 


\section{Project Profile: Niagara Mohawk's Nuclear Generation Performance Improvements}

Niagara Mohawk Power Corporation (NMPC), an investor-owned utility serving large sections of upstate New York, was one of the reporters that reported major reductions in carbon dioxide emissions through nuclear plant availability improvements. NMPC is the operator and part owner of Nine Mile Point, a 1,672megawatt nuclear generating station in Scriba, New York. In its Form EIA-1605 report, NMPC described its availability improvement project at Nine Mile Point as follows:

NMPC owns $100 \%$ of the $610 \mathrm{MW}$ Nine Mile Point Unit 1 and 41\% of the 1062 MW Unit 2. In previous years, both units had experienced low capacity factors. However, since 1990, NMPC has undertaken a number of deliberate steps to improve the units' performance. The program began by engaging new management leadership, reorganizing the nuclear business unit, and establishing $a$ restructured business planning process. Operating procedures were then revised; management incentives were tied to performance targets; and programs were developed to improve thermal performance, reduce lost capacity, and increase unit availability. A large number of equipment changes and upgrades were also implemented at both units.

Specific actions taken toward improving plant reliability and availability include:

- Implementing less frequent refueling outages for Unit 1 (now on a 24-month cycle instead of 18 months, effective in 1991).
- Taking steps to shorten the number of days for each refueling outage. The total outage time for rejueling the units in the 1990-1993 period was significantly reduced for both units, relative to rejuelings in 1990. In 1993, the target number of refueling days was met or exceeded (i.e., refueling was complete in fewer days than targeted for both units).

- Implementing improvements, repairs and eqiaipment replacements to reduce forced outages and automatic shutdowns. Forced and other maintenance outages have shown considerable improvement since 1990 ... .

Over the period 1987 through 1990, the two nuclear units produced about 30 percent of the maximum amount of generation they could produce if they operated $100 \%$ of the time. As a result of NMPC's actions, the combined average capacity factor improved to over 70\% during the 1991-1994 time period. In 1994, the units achieved their highest annual output levels, with capacity factors of about $92 \%$ and $90 \%$, respectively.

Total cunulative reductions in carbon dioxide emissions compared with 1990 were estimated to exceed 11 million metric tons. The emissions reductions were achieved when generation from Nine Mile Point displaced fossil fuel generation. It should be noted that NMPC reported only 41 percent (its ownership share) of the emissions reductions for Unit 2.

\section{Transmission and Distribution Projects}

Transmission and distribution projects, although not as popular as generation projects, were nonetheless reported in significant numbers. A total of 49 transmission and distribution projects (26 percent of the total) were reported (Figure 5). In terms of average emissions reductions per project, the transmission and distribution projects are typically about an order of magnitude smaller than the generation projects. While there are numerous opportunities for improving efficiencies in the delivery of electricity, the magnitude of the efficiency gains that can be realized is limited. Transmission and distribution system losses in the United States are typically on the order of 5 to 7 percent of the total energy flow through the system. Potential reductions in these losses attainable through such means as "reconductoring" and the installation of high-efficiency transformers are smaller still. Nonetheless, a reduction of 1 percentage point in system losses can represent a significant efficiency improvement.

The three most frequently reported types of transmission and distribution projects were (1) highefficiency transformers (including improved silicon steel and amorphous core transformers), (2) reconductoring (replacing existing conductors with large-diameter conductors to reduce line losses), and (3) distribution voltage upgrades (increasing the voltage at which the various segments of the system operate, to reduce line losses). Figure 5 shows the number of reported projects for each type. Installation of high-efficiency transformers was the most frequently reported type of project. A. total of 16 such projects were reported, ${ }^{16}$

\footnotetext{
${ }^{16}$ Including 2 "hybrid" projects combining the installation of high-efficiency transformers with other emissions reduction actions.
} 
along with 10 reconductoring projects ${ }^{17}$ and 12 distribution voltage upgrade projects. ${ }^{18}$ High-efficiency transformer projects tended to be somewhat smaller than the other project types.

\section{Cogeneration and Waste Heat Recovery}

\section{Background}

Cogeneration is the sequential production of useful thermal energy, such as steam and hot water, and electricity from the same energy source. It is generally associated with energy-intensive industries such as petroleum refining, chemicals, pulp and paper, and primary metals. Cogeneration projects are typically either topping or bottoming cycles. In a topping cycle, the primary source of energy is used to produce electricity, with the thermal energy recovered from that process used in subsequent applications. Topping cycles are widely used in industry and in power plants that sell electricity and steam to customers. In bottoming cycles, the primary energy source provides process heat, from which waste heat is subsequently used to generate electricity. Bottoming cycle applications are less common and are usually associated with hightemperature industrial processes.

The cogeneration projects reported involved utilities that teamed up with industry partners to supply thermal energy and meet electricity needs. Cogeneration projects can combine very high thermal efficiencies with short construction lead times and relatively low capital costs. Thus, cogenerated power can often be very attractive, where feasible.

\section{Projects Reported}

There were only four reporters of cogeneration projects who did not request confidentiality, and each of the four reported only one project (see box at right). All four were electric utilities (SIC 49) participating in the Climate Challenge program.

The four cogeneration and waste heat recovery projects reported are located in Illinois, Mississippi, Pennsylvania, and Texas. Three of the four projects came on line in 1994. The industrial partners in these projects were a grain processor, a greenhouse, and two large industrial customers. Three of the four projects reported using natural-gas-fired cogeneration systems; one reported bituminous coal and diesel fuel. All the projects

\section{Cogeneration Reporters}

- Central Illinois Light Company built a 16-megawatt natural-gaś-firê the steam and electricity needss of Midwest Grain Products, which has retired its own coal-fired fluidized-bed and less efficient gas-fired boilers.

- General Public Utilities Corporation uses the waste heat from a portion of the water exiting the condensers at its Homer City Generating Station to heat an 11.5-acre greenhouse. The water flows through a network of pipes beneath the greenhouse and heats the floor to a constant 97 degrees Fahrenheit, replacing propane heating.

- Houston Lighting \& Power Gompany has commenced operation of its San Jaeinto Steam Electric Generating Station, which will provide 162 megawatts of capacity to the grid while also providing process steam to an adjacent DuPont facility, replacing oldẹr and less efficient boilers.

- The Southern Company upgraded an existing gas-fired cogeneration facility to provide electricity and process. steam to a large industrial customer, replacing some of its own coal-fired generation as well as the customer's less efficient natural-gasfired boilers.

used topping cycles. Reported end uses of thermal energy were limited to electricity generation and process heat applications.

The four reporters reduced their own carbon dioxide emissions (direct reductions) by 102,000 metric tons in 1994 as a result of the cogeneration projects. Emissions reductions resulting from the elimination or replacement of older and less efficient coal- or gas-fired boilers owned by the industrial partners (indirect reductions) were estimated at approximately 144,000 metric tons of carbon dioxide in 1994.

One utility also reported plans for three cogeneration projects scheduled to go on line during 1996-1997 at three steel plants. Two of the projects will use blast furnace gas in currently underutilized boilers in order to reduce the steelmakers' demand for electricity; the third will be a natural gas combined-cycle project designed to meet another steel mill's electricity and steam needs. The utility estimates that the three projects will displace approximately 1,500 gigawatthours of its generation.

\footnotetext{
${ }^{17}$ Including 6 hybrid projects.

${ }^{18}$ Including 8 hybrid projects.
} 
Coverage of cogeneration projects in the Voluntary Reporting Program is low. Approximately 1,267 "qualifying facilities" reported generating electricity in 1994, with a capacity of about 54 gigawatts. These plants generated 292,000 gigawatthours in 1994. About twothirds of "qualifying facility" capacity is attributable to cogeneration. ${ }^{19}$

\section{Energy End Use}

\section{Background}

Energy efficiency and load management can reduce energy consumption and greenhouse gas emissions. The emphasis given to energy efficiency, minimum efficiency standards, and integrated resource planning in the Energy Policy Act of 1992 underscores the importance of these measures in meeting greenhouse gas emissions reduction goals.

Energy efficiency measures include the use of more efficient equipment and appliances, lighting and lighting controls, and building shells, urban forestry, variable speed motors, and improved industrial processes. Utilities also use load management programs, such as direct load control, interruptible load, and load shifting, to influence the amount and timing of end-use energy consumption.

The energy end-use projects reported involved utilities, manufacturers, and private households. Utilities see energy efficiency and load management as means to delay the need for additional generating capacity and reduce power purchases. In 1994 alone, U.S. electric utilities reported demand-side management savings of 52,483 million kilowatthours and peak load reductions of 25,001 megawatts. $^{20}$

\section{Projects Reported}

A total of 207 energy end-use projects were reported, representing approximately one-third of all the projects reported. A total of 77 entities reported energy end-use projects, 52 of them on the long form. Almost all were utilities (SIC 49), with the exceptions of one representative each from the chemicals and allied products (SIC 28), electronic and other electrical equipment (SIC 36), and transportation equipment (SIC 37) industries and two private households (SIC 88). Of the energy end-use projects reported, 186 were part of Climate Challenge efforts, 15 part of the Green Lights program, 2 part of the Energy Star Computers program, and 1 part of the Energy Star Building program. A small number of enduse projects were also undertaken as a result of other Federal, State, and local programs.

End-use projects most frequently targeted lighting and lighting controls, followed by equipment and appliances, and heating, ventilation, and air-conditioning (HVAC) (Figure 8). Most of the projects reported addressed multiple end uses. The first reporting cycle also included five urban forestry projects (Figure 8). Buckeye Power's promotion efforts resulted in the installation of 1,300 geothermal heat pumps since 1991; PacifiCorp reported on a solar water heater program for residential customers; the Detroit Edison Company reported on energy savings from its Energy Partnership, in which the utility helps devise energy conservation options for its industrial customers; and the Vermont Public Power Supply Authority's submission included a similar effort for dairy farmers.

\section{Figure 8. End-Use Projects by Project Type}

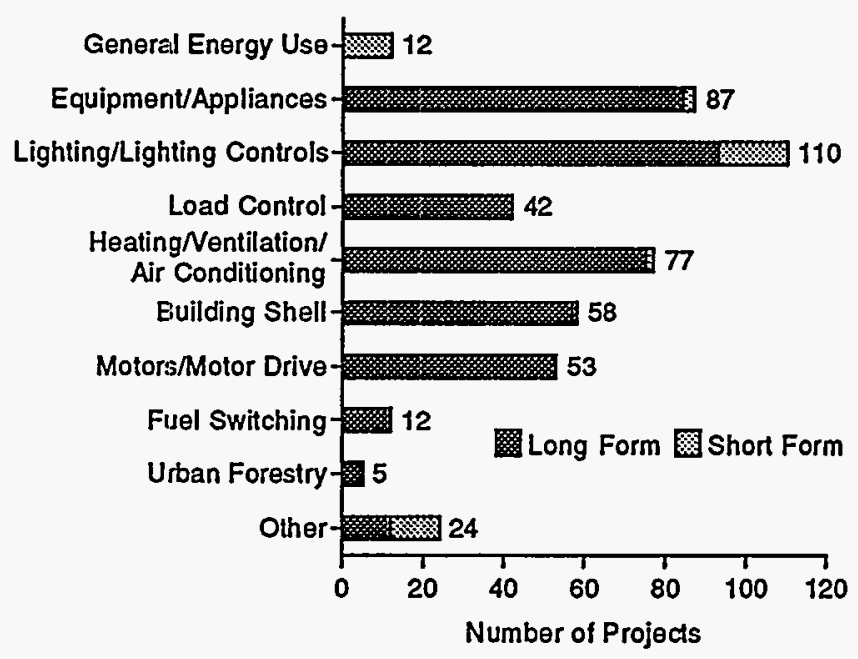

Note: Some projects may be counted in more than one category. Source: Energy Information Administration, Forms EIA-1605 and EIA-1605EZ (1995 reporting cycle).

The three participating manufacturers - General Motors, IBM, and Johnson \& Johnson-reported a total of seven projects. All indicated having undertaken measures affecting energy end use through equipment and appliance, lighting and lighting controls, HVAC, and motor and motor drive projects. Johnson \& Johnson also reported electricity and fuel savings from process

\footnotetext{
${ }^{19}$ Energy Information Administration, Electric Power Annual 1994, Volume II, DOE/EIA-0348(94/2) (Washington, DC, November 1995), Pp. 13, 95, 98.

${ }^{20}$ Energy Information Administration, U.S. Electric Utility Demand-Side Management 1994, DOE/EIA-0589(94) (Washington, DC, December 1995), p. 4.
} 


\section{PacifiCorp's Salt Lake Otýthoan Forrestry Project}

PacifiCorp planted appioxinatel 1300 ideciauous

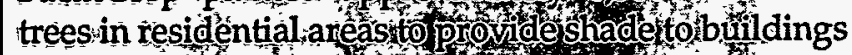
and reduce energy us or or cooling ln its report,

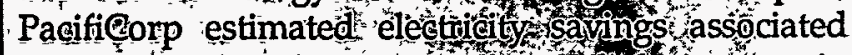

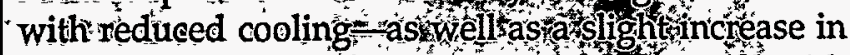
natural gas consumption fon heath the diminished amount of sun reaching the buildings in winter for the fiọst yeân of the project (1994).

For a single-family home in Salt take city with 1 tree planted, energy savingsare stimated att 265 kilowatthouns per home using conventional air çonditioning and 48.1 kilowatthouis perthome unsing evaporative coolens For a single family tho me with 2 trees planted, energy savings are estimatedat 4 gloilowathours per

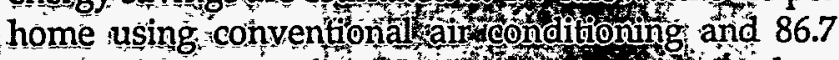
kilowatthouns per home using evaporative colers. Approximately half of thesing in evamoly homesin the project use air conditioning and half use evaporative coolens, PacifiCorp assumestuatothe smallinerease in winter heating requirements is met with havinal gas. In 1994, the average decrease nenergy eonsumption for each home with one tree ps 248000 Btu ând for each home with two treesis $406 \% 000 \%$ ptu:
The project assumes that trees planted around multifamily dwellings: are only one-third as efficient at saving energy as those planted around single-family homes. Multi-family dwellings, all of which have evaporative coolers, use an average 2,110 kilowatthours each, resulting in first year savings of 85.9 kilowatthours. There are no increases in heating requirements for multi-family dwellings.

For 1994, the first full year of the Salt Lake City Urban Forestry Program, PacifiCorp reported electricity savings of 170.65 megawatthours and an increase in natural gas consumption of 261.8 million Btu. PacifiCorp applied an average carbon dioxide emissions factor of 0.9487 metric tons per megawatthour, based on its actual.generation.mix for 1994, and a carbon dioxide emissions factor for natural gas of 0.0528 metric tons per million Btu. The total reported direct carbon dioxide reductions, associated with the electricity savings, were 161.9 metric tons, while the increase in natural gas consumption contributed 13.83 metric tons in indirect carbon dioxide emissions. improvements. The two reporting households listed a total of five end-use projects, which involved lighting and lighting controls, equipment and appliances, and HVAC. The remaining 196 projects were reported by utilities. Project descriptions indicate that utilities used rebates, energy audits, and other promotional efforts to encourage participation in demand-side management programs.

End-use projects were reported in the residential, commercial, industrial, and agricultural sectors (Figure 9). It is not possible to rank the savings achieved in the individual sectors since reporters sometimes listed several end-use programs collectively as one project; however, the aggregate electricity savings resulting from end-use projects reported are estimated at approximately 12,000 gigawatthours for 1994 (Table 13).

Total carbon dioxide emissions reductions reported on the short form for 1994 totaled 1.4 million metric tons; however, the short form does not distinguish between direct and indirect emissions reductions. Direct emissions reductions for 1994 resulting from energy end use improvements are estimated at 9 million metric tons (Table 14). Carbon dioxide emissions reductions reported for individual projects ranged from less than 1 metric ton to more than 1 million metric tons, primarily because of the flexibility allowed in defining the scope of a project, which could be limited to compact fluorescent light bulb installation reported by a household or could encompass a utility's system-wide demand-side management achievements.

Figure 9. End-Use Projects by Sector

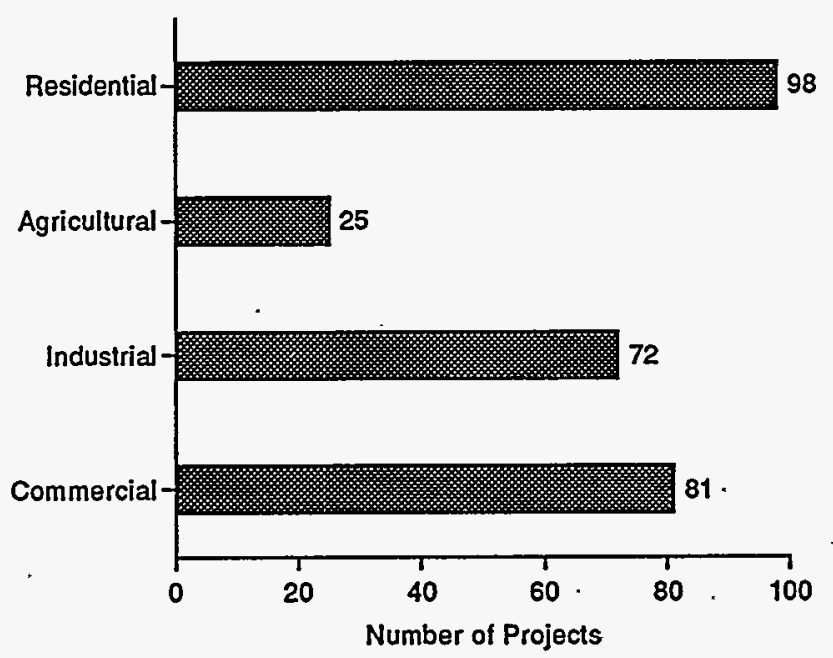

Note: Some projects may be counted in more than one category. Source: Energy Information Administration, Form ElA-1605, "Voluntary Reporting of Greenhouse Gases" (1995 reporting cycle). 


\section{Project Profile: Allegheny Power Service Corporation}

Allegheny Power Service Corporation (APSC) of Greensburg, Pennsylvania, filed Form EIA-1605 as an agent for Monongahela Power Company, The Potomac Edison Company, and West Penn Power Company. APSC reported on four energy end-use projects throughout its service territory in Maryland, Ohio, Pennsylvania, Virginia, and West Virginia.

Project 1: Demand-Side Management Programs. APSC reported all energy savings and emissions reductions for its demand-side management programs as one project. Residential sector measures include thermal treatment for new construction and existing customers, water heating conservation, add-on heat pumps, heat pump maintenance, and high-efficiency heat pumps. Commercial sector efforts focus on thermal treatment for new and existing facilities, energyefficient lighting, and HVAC modifications. The industrial program promotes energy-efficient motors, energy-efficient lighting, and demand control. APSC estimates that from 1995 through 2000 it will spend over $\$ 39$ million on demand-side management efforts.

Project 2: Green Lights Utility Ally Program. APSC reported the effects and emissions reductions attributed to energy-efficient lighting upgrades in facilities covered by the Green Lights program. APSC companies agreed to (1) complete energy-efficient lighting upgrades for 90 percent of the square footage of their facilities wherever profitable, while maintaining or improving lighting quality; (2) assist the EPA in marketing the benefits of Green Lights and energyefficient lighting technologies to industrial and commercial customers; (3) participate in an ongoing lighting product information program and employee education programs with regard to energy-efficient lighting; and (4) assist the EPA in documenting the savings from energy-efficient lighting upgrades within their service areas.

Project 3: Heat Pipe Heat Exchanger Project. Starting in 1991, APSC's West Penn Power Company began field-testing an advanced heat pipe heat exchanger in the air-conditioning system of a 50,000-square-foot Bi-Lo Supermarket in State College, Pennsylvania. The air conditioning system is a 60-ton dual-path rooftop unit that uses separate compressor/coil sets to condition outdoor ventilation air and indoor air. A heat pipe heat exchanger was installed in the dry air system to improve the rate of moisture removal from outdoor ventilation air.

Project 4: Adjustable Speed Drives (ASD) for Plastic Injection Molding Machines. This cooperative research project with an industrial customer and the Electric Power Research Institute began evaluating the use of ASDs on plastic injection molding machines. ASDs were installed on 18 motors for 7 different molding machines. Measured savings were 38 percent for total electric motor load and 23 percent for total molding machine load.

To calculate the carbon dioxide emissions reductions associated with these reductions in electricity consumption, APSC applied a loss factor of 0.90395 to determine the equivalent power generated at a power station in the system and an average system generation emissions coefficient of 0.9253 metric tons of carbon dioxide per megawatthour. For 1994, total direct reductions of 290,561 metric tons were reported for APSC's energy end-use projects.

Electricity Savings Reported for End-Use Projects, 1991-1994 (Megawatthours)

\begin{tabular}{|c|c|c|c|c|}
\hline Project Type & 1991 & 1992 & 1993 & 1994 \\
\hline Demand-Side Management & 62,756 & 132,499 & 181,914 & 282,622 \\
\hline Green Lights Utility Ally & - & - & 264 & 528 \\
\hline Heat Pipe Heat Exchanger & 132 & 176 & 176 & 176 \\
\hline Adjustable Speed Drives . & - & -- & - & 572 \\
\hline Total .... & 62,888 & 132,675 & 182,354 & 283,898 \\
\hline
\end{tabular}

Total Direct Carbon Dioxide Emissions Reductions, 1991-1994 (Metric Tons)

\begin{tabular}{c|c|c|c|c}
\hline & 1991 & 1992 & 1993 & 1994 \\
\hline Direct Reductions . . . . . . . $\ldots \ldots$ & 64,377 & 135,815 & 186,670 & 290,561 \\
\hline
\end{tabular}

Source: Energy Information Administration, Form ElA-1605, "Voluntary Reporting of Greenhouse Gases" (1995 reporting cycle). 
Table 13. Electricity Savings Reported for End-Use Projects, 1991-1994 (Megawatthours)

\begin{tabular}{cc}
\hline Year & Electricity Savings \\
\hline $1991 \ldots \ldots \ldots \ldots$ & $1,457,584$ \\
$1992 \ldots \ldots \ldots \ldots$ & $3,880,211$ \\
$1993 \ldots \ldots \ldots \ldots$ & $6,989,815$ \\
$1994 \ldots \ldots \ldots$ & $12,016,104$ \\
\hline
\end{tabular}

Source: Energy Information Administration, Forms ElA1605 and EIA-1605EZ, "Voluntary Reporting of Greenhouse Gases" (1995 reporting cycle).

Table 14. Carbon Dioxide Reductions Reported for End-Use Projects, 1991-1994 (Metric Tons)

\begin{tabular}{cc|c|c}
\hline \multicolumn{2}{c|}{ Year } & $\begin{array}{c}\text { Direct } \\
\text { Reductions }\end{array}$ & $\begin{array}{c}\text { Indirect } \\
\text { Reductions }\end{array}$ \\
\hline $1991 \ldots \ldots \ldots \ldots$ & $2,786,573$ & 303,075 \\
$1992 \ldots \ldots$ & $4,551,198$ & 624,093 \\
$1993 \ldots \ldots$ & $\ldots \ldots$ & $6,795,856$ & 833,241 \\
$1994 \ldots \ldots \ldots$ & $9,017,178$ & $1,324,481$ \\
\hline
\end{tabular}

Source: Energy Information Administration, Form ElA1605, "Voluntary Reporting of Greenhouse Gases" (1995 reporting cycle).

Utilities using demand-side management to reduce their own generation reported 8.9 million metric tons in direct carbon dioxide reductions. Utilities implementing end-use modifications to reduce power purchases or emissions from sources not owned or leased by the reporting entity achieved an estimated 1.1 million metric tons in indirect carbon dioxide reductions. Manufacturers reported 94,000 metric tons in direct carbon dioxide reductions and 263,000 metric tons in indirect reductions. Emissions reductions for 1994 reported by participating households were 0.18 metric tons of direct carbon dioxide reductions and 0.75 metric tons of indirect reductions. Total reported reductions from energy enduse projects alone represent approximately 18 percent of the total carbon dioxide emissions reductions reported during the first year of the Voluntary Reporting Program.

\section{Transportation and Off-Road Vehicles}

\section{Background}

The transportation sector currently produces about onethird of U.S. carbon dioxide emissions and is expected to be the fastest-growing source of this gas through the year 2000. Figure 10 shows the recent trends in carbon dioxide emissions from the U.S. transportation sector. Carbon dioxide results from the combustion of fossil fuels, including gasoline, diesel, jet fuel, and natural gas. Emissions from the transportation sector currently exceed 430 million metric tons of carbon annually. ${ }^{21}$ Because of the growth in vehicle miles traveled, carbon dioxide emissions from fuel combustion in transportation have increased by 6 percent since 1987. The increase was moderated somewhat by improved average fuel economy of road vehicles following the "oil price shocks" of the 1970s, but average fuel economy has stabilized and even begun to decline in recent years.

\section{Figure 10. Trends in Carbon Dioxide Emissions from the U.S. Transportation Sector, 1987-1994}

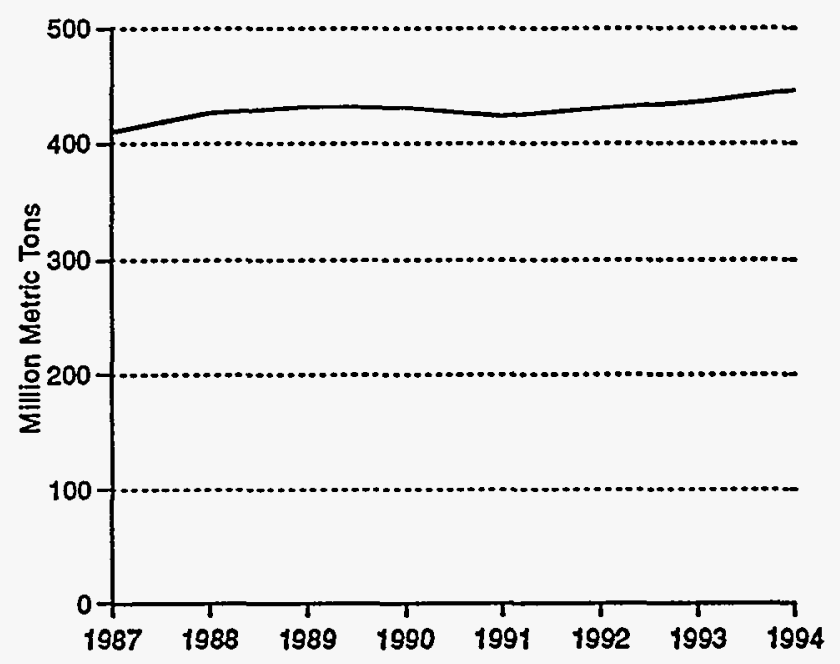

Source: Energy Information Administration, Emissions of Greenhouse Gases in the United States 1987-1994 (DOE/EIA-0573(87-94) (Washington, DC, October 1995), p. 12.

Most motor-vehicle-related environmental regulations are aimed at controlling emissions of the "criteria pollutants" that cause urban air pollution, but measures that reduce the use of motor vehicles-such as increased use of mass transit, carpooling, and telecommuting-will also reduce greenhouse gas emissions, as

\footnotetext{
${ }^{21}$ Energy Information Administration, Emissions of Greenhouse Gases in the United States 1987-1994, DOE/EIA-0573(87-94) (Washington, DC, October 1995), p. 12.
} 
will measures that increase vehicle fuel efficiency, such as fuel efficiency standards. On the other hand, measures specifically designed to reduce emissions of criteria pollutants-including pollution control equipment, changing the composition of gasoline, and switching to alternative transportation fuels-may have more complicated and uncertain consequences for greenhouse gas emissions.

Provisions intended to increase the use of alternative transportation fuels (ATFs) have been included in three major Acts: the Alternative Motor Fuels Act of 1988, the Clean Air Act Amendments of 1990, and the Energy Policy Act of $1992 .^{22}$ The use of alternative transportation fuels has ambiguous implications for greenhouse gas emissions. Whereas the use of electricity virtually eliminates vehicle emissions, with dramatic impacts on local air quality, the emissions are effectively transferred to the power plants providing the electricity to recharge batteries for electric vehicles. If the electric power is generated by coal, the result may be a net increase in emissions.

The use of compressed natural gas (CNG) and liquefied natural gas (LNG) in vehicles provides significant air quality benefits from reductions in emissions of carbon dioxide, carbon monoxide, and ozone precursors; however, their use increases methane emissions, both in the transmission and distribution of natural gas and in vehicle operation and maintenance. Methane emissions are not an urban air pollution problem, since methane is a relatively unimportant ozone precursor, ${ }^{23}$ however, given methane's large global warming potential, they may offset to some degree the reduction in carbon dioxide emissions afforded by natural gas.

\section{Projects Reported}

A total of 33 transportation projects were reported by 26 entities (Figure 11). Detailed information was provided for 26 (79 percent) of the projects on Form EIA1605. Summary data for the remaining 7 projects were reported on the short form. The projects reported fall into two main areas: alternative-fuel vehicles (22 projects or 67 percent) and transportation demand reduction ( 9 projects or 27 percent). Two projects involved the operation of more efficient vehicles. The vast majority of the projects ( 91 percent) involved road vehicles.

The primary effect of the transportation projects reported was to reduce emissions of carbon dioxide, although
Figure 11. Transportation Projects by Project Type

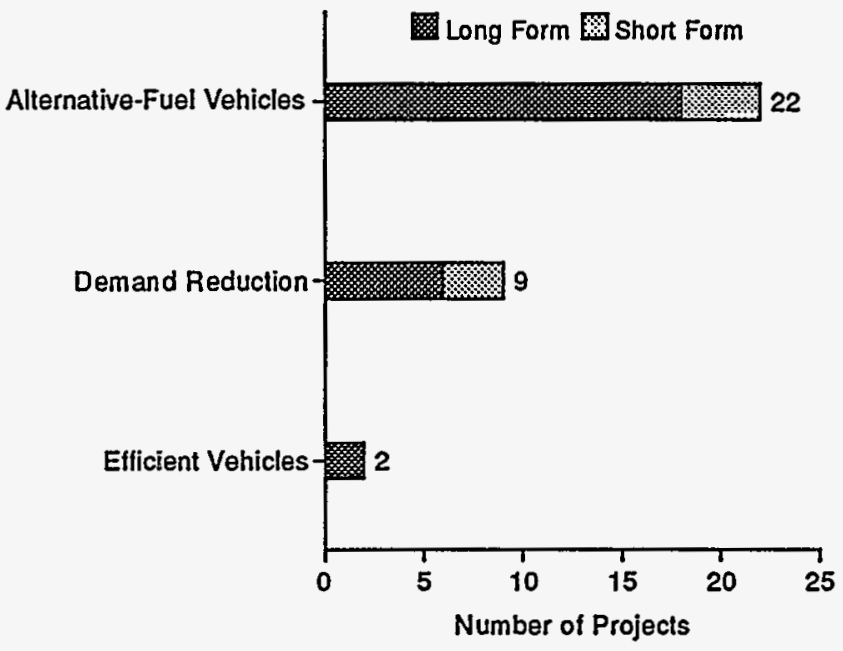

Source: Energy Information Administration, Forms ElA-1605 and ElA-1605EZ, "Voluntary Reporting of Greenhouse Gases" (1995 reporting cycle).

reductions in emissions of nitrous oxide and methane were also reported for two projects. Table 15 shows the share by project type of the total carbon dioxide emissions reductions reported for transportation projects in 1994. Alternative-fuel vehicles accounted for 67 percent of the total emissions reduction, efficient vehicles for 30 percent, and demand reduction for 3 percent.

Table 15. Carbon Dioxide Emissions Reductions by Transportation Project Type (Metric Tons)

\begin{tabular}{|c|c|c|c|}
\hline \multirow[b]{2}{*}{ Project Type } & \multicolumn{3}{|c|}{ Reductions Reported } \\
\hline & $\begin{array}{l}\text { Long } \\
\text { Form }\end{array}$ & $\begin{array}{l}\text { Short } \\
\text { Form }\end{array}$ & Total \\
\hline Alternative-Fuel Vehicles ... & 4,428 & 10,396 & 14,823 \\
\hline Demand Reduction & 293 & 301 & 594 \\
\hline Efficient Vehicies & 6,729 & 0 & 6,729 \\
\hline Total $\ldots \ldots \ldots$ & 11,449 & 10,697 & 22,146 \\
\hline
\end{tabular}

Source: Energy Information Administration, Forms EIA1605 and EIA-1605EZ, "Voluntary Reporting of Greenhouse Gases" (1995 reporting cycle).

For 5 of the 33 transportation projects reported, emissions reductions either were not estimated or were not achieved due to the research and development nature of the projects. Figure 12 shows the relative size of the carbon dioxide reductions for the other 28 projects. In

\footnotetext{
${ }^{22}$ Energy Information Administration, Alternatives to Traditional Transportation Fuels: An Overview, DOE/EIA-0585/O (Washington, DC, June 1994), p. 33.

${ }^{23}$ Energy Information Administration, Alternatives to Traditional Transportation Fuels: An Overview, DOE/EIA-0585/O (Washington, DC, June 1994), p. 98.
} 
Figure 12. Transportation Emissions Reduction Projects by Project Type and Size

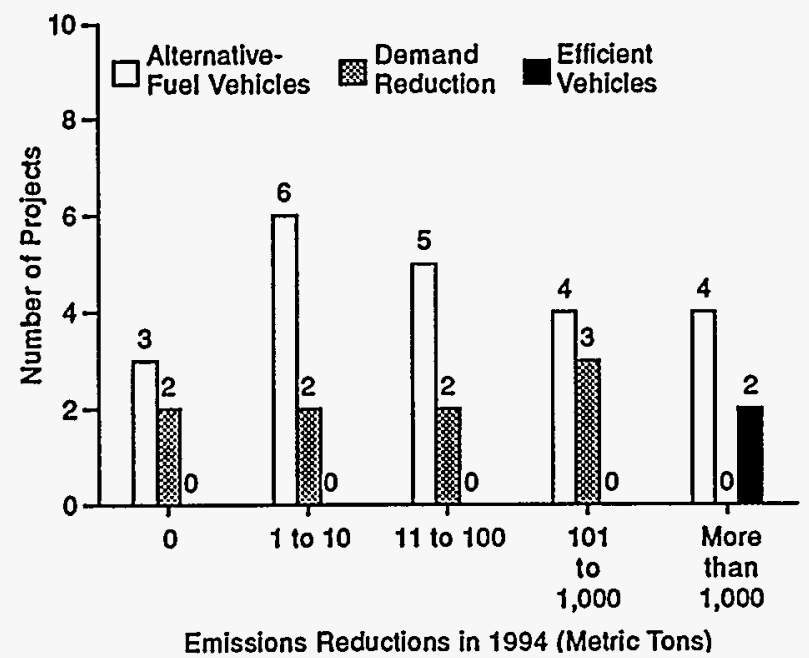

Source: Energy Information Administration, Forms EIA-1605 and ElA-1605EZ, "Voluntary Reporting of Greenhouse Gases" (1995 reporting cycle).

general, the emissions reductions achieved by transportation projects are quite modest. More than half of the projects achieved carbon dioxide reductions of less than 100 metric tons each in 1994. Yet the level of activity necessary to reduce emissions by more than 100 metric tons is not inconsequential. For example, to reduce carbon dioxide emissions by 107 metric tons, Cinergy operated a fleet of 105 alternative-fuel vehicles using CNG and propane. General Public Utilities reduced vehicle travel by 366,000 miles to reduce emissions by 147 metric tons. Nevertheless, full-scale transportation projects involving large vehicle fleets can achieve substantial reductions. Natural gas vehicles operated by Pacific Gas \& Electric (reported as two projects on the short form) reduced carbon dioxide emissions by more than 10,000 metric tons in 1994 .

Twenty projects involving operation of alternative-fuel vehicles accounted for 70 percent of the total reduction in carbon dioxide emissions reported for transportation projects in 1994. At least 97 percent of the reductions were attributed to vehicles using natural gas. Natural gas was used in 14 alternative-fuel vehicle projects, and in 11 it was the only alternative fuel used. Seven projects involved the operation of electric vehicles. Of these, 5 were exclusively electric vehicle projects; however, the emissions reductions reported for 1994 were relatively insignificant (less than 0.1 percent of the total for alternative-fuel vehicles). Other alternative transportation fuels included in transportation reports were propane, ethanol, and M-85 (a blend of 85 percent methanol and 15 percent gasoline).
Two of the 22 alternative-fuel vehicle projects were oriented toward research and development (R\&D). These projects were a range of $R \& D$ activities conducted or sponsored by The Southern Company, including the United States Advanced Battery Consortium, the Electric Power Research Institute's Electric Transportation Business Unit and the Electric Vehicle Research Network, and Public Utility District No. 1 of Snohomish County's sponsorship of an annual batteryand solar-powered boat race.

Offsetting increases in fuel-cycle emissions were reported for only one alternative-fuel vehicle project. Sierra Pacific Power Company reported that operation of its fleet of 43 dual-fuel vehicles and 1 dedicated CNG vehicle increased methane emissions by 0.4 metric tons, equivalent to 17 percent of the reduction in carbon dioxide emissions (assuming a 100-year global warming potential of 24.5 for methane).

Transportation demand reduction accounted for 3 percent of the total reduction in carbon dioxide emissions reported for transportation projects in 1994. Of the 9 demand reduction projects reported, 7 involve employee commute reduction (4 projects) or company vehicle use reduction ( 3 projects) conducted by electric utilities. Employee commute reduction efforts ( 3 projects) accounted for 54 percent of the carbon dioxide emissions reductions reported for demand reduction. These projects included carpooling, increased use of mass transit, compressed work weeks, and subscription bus service. Public Utility District No. 1 of Snohomish County also reported an employee commute reduction program; however, emissions reductions associated with the program were not estimated.

Three other utilities reported on efforts to reduce vehicle miles driven by corporate vehicles, which together accounted for 45 percent of the carbon dioxide emissions reductions reported for demand reduction projects. Texas Utilities Electric Company reported that use of fleet vehicles has been reduced through more efficient dispatching (including modifying service routes to put workers closer to work areas) and corporate downsizing. General Public Utilities Corporation implemented a video conferencing system in 1991 that reduced employee travel by nearly 1 million miles between 1991 and 1994 (see box on page 34). The Public Utility District No. 1 of Snohomish County began a pilot program in which bicycles were used by meter readers on suitable routes (emissions reductions were not estimated). Two residential sector reporters reported demand reduction projects that accounted for 1 percent of the total carbon dioxide emissions reduction for this category in 1994. 


\section{Video Conferencing by General Public Utilities Corporation}

General Public Utilities Corporation (GPU) is a large, investor-owned electric utility with customers in New Jersey, Pennsylvania, and New York. In 1991, GPU installed a video conferencing system interlinking the primary locations of its four operating companies: Jersey Central Power \& Light, Pennsylvania Electric Company, Metropolitan Edison Company, and GPU Nuclear Corporation. The system allows GPU to conduct interactive business meetings among groups at the different locations. In addition to eliminating emissions from companyowned vehicles, GPU also eliminates the expense and unproductive time of travel.

GPU conservatively estimates that in the 4 years since introducing video conferencing, it has saved nearly 1 million miles of automobile travel. Furthermore, as shown below, savings have increased each year since the introduction of the system as employees have become accustomed to its use. The savings in vehicle miles traveled have translated primarily into reductions in emissions of carbon dioxide (388 metric tons over 4 years), and smaller reductions in emissions of methane (237 kilograms) and nitrous oxide ( 55 kilograms) have also been achieved. Although the savings are modest in relation to GPU's emissions as a whole, video conferencing is applicable to a wide variety of companies that operate at multiple locations.

\section{Travel Savings from Video Conferencing}

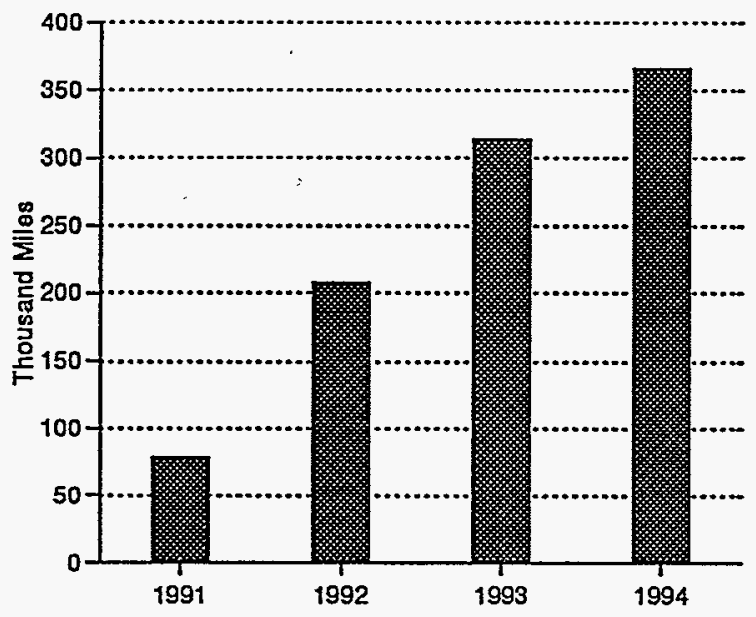

Source: Energy Information Administration, Form ElA-1605, "Voluntary Reporting of Greenhouse Gases" (1995 reporting cycle).
Two projects involving the operation of more efficient vehicles were reported, both of which achieved relatively large enissions reductions (more than 1,000 metric tons in 1994). The Tennessee Valley Authority has increased the fuel efficiency of its fleet vehicles since 1990, yielding cumulative savings in carbon dioxide emissions of more than 10,000 metric tons. Union Electric Company built lighter, aluminum railroad cars to replace steel cars transporting coal from Wyoming and Colorado to its plants in Missouri. Using these cars, Union Electric was able to transport 3 percent more coal per trainload, which resulted in a reduction in the total number of trainloads required, thus reducing indirect carbon dioxide emissions from the diesel locomotives pulling the trains.

\section{Methane Emissions Reductions}

\section{Background}

Total U.S. methane emissions in 1993 were approximately 26.6 million metric tons. Marginal additions of methane to the atmosphere have a heat-trapping capacity some 24.5 times that of carbon dioxide on a per-ton basis. ${ }^{24}$ Thus, 26.6 million metric tons of methane is equivalent to 652 million metric tons of carbon dioxide, or 178 million metric tons of carbon. Because of its substantially higher global warming potential, methane was responsible for almost 11 percent of U.S. greenhouse gas emissions (weighted for global warming potential) in 1993.

There are four principal sources of methane: fugitive emissions from coal mines; natural gas production, processing, and distribution; anaerobic (the absence of oxygen) decomposition of landfill waste; and emissions from domesticated livestock. Together, these sources represent 95 percent of all methane emissions. ${ }^{25}$ Methane emissions in 1993 were more than 1.3 million metric tons below their 1990 level, primarily because emissions from coal mines declined by more than 1 million metric tons and, secondarily, because emissions from landfills fell by 400,000 metric tons (Figure 13).

\section{Projects Reported}

A total of 43 methane reduction projects were reported by 20 entities. The reported projects fall into two main areas: energy production from recovered methane $(30$ projects, or: 70 percent) and reductions in methane vented or leaked from natural gas distribution pipelines

${ }^{24}$ D.L. Albritton et al., "Trace Gas Radiative Forcing Indices," in J.T. Houghton et al., Climate Change 1994 (Cambridge, UK: Cambridge University Press, 1995), p. 222.

${ }^{25}$ Energy Information Administration, Emissions of Greenhouse Gases in the United States 1987-1994, DOE/EIA-0573(87-94) (Washington, DC, October 1995), p. 25. 
Figure 13. U.S. Methane Emissions, 1987-1993

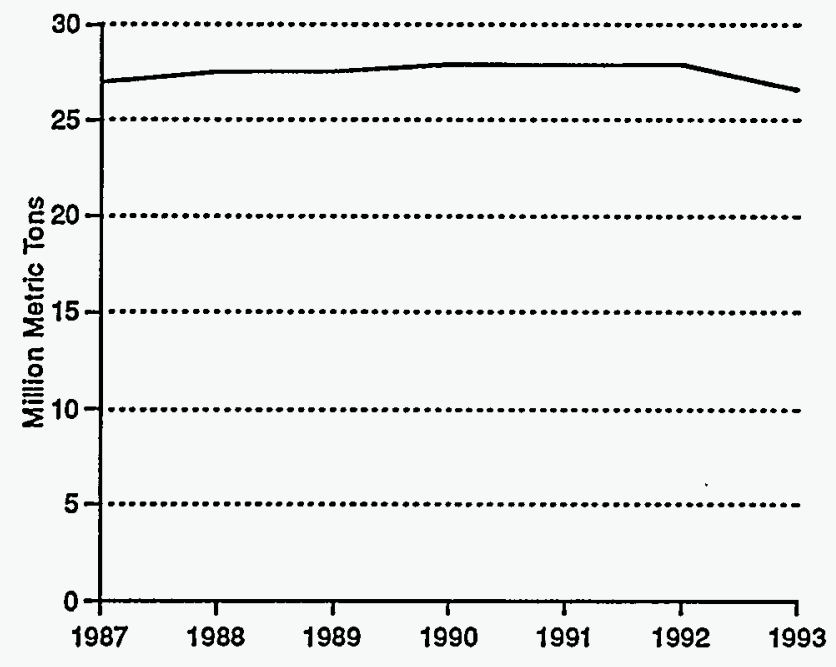

Source: Energy Information Administration, Emissions of Greenhouse Gases in the United States 1987-1994, DOE/EIA-0573(87-94) (Washington, DC, October 1995), Table ES1, p. ix.

and equipment (10 projects, or 23 percent). Most energy recovery projects took place at landfills, two recovered methane from wastewater treatment plants, two recovered methane from coal mines, and two recovered methane from animal waste.

For six projects (including three landfill projects) no direct reductions of methane emissions were reported. One project, financed by Houston Light \& Power, involved a study of methods to reduce emissions from rice fields; another project, reported by the United Power Association, used refuse-derived fuel directly in a boiler.

For the 37 projects that showed reductions in methane emissions during 1994, reductions ranged from several metric tons to more than 35,000 metric tons. The project that recovered 35,000 metric tons of methane, reported by Wisconsin Electric Power, combined reductions associated with energy purchases from five separate landfills. Most natural gas system projects reduced emissions by less than 1,000 metric tons during 1994, while the typical landfill gas-to-energy project reduced emissions by between 1,000 and 10,000 metric tons. All reported projects that reduced methane emissions by more than 10,000 metric tons in 1994 took place at either landfills or coal mines (Table 16).
Table 16. Methane Emissions Reduction Projects by Project Type and Size

(Number of Projects)

\begin{tabular}{|c|c|c|c|c|}
\hline \multirow[b]{2}{*}{ Project Type } & \multicolumn{4}{|c|}{$\begin{array}{l}\text { Emissions Reductions in } 1994 \\
\text { (Metric Tons of Methane) }\end{array}$} \\
\hline & $\begin{array}{l}\text { Less } \\
\text { than } \\
1,000\end{array}$ & $\begin{array}{c}1,000 \\
\text { to } \\
10,000\end{array}$ & $\begin{array}{c}10,000 \\
\text { to } \\
20,000\end{array}$ & $\begin{array}{c}\text { More } \\
\text { than } \\
20,000\end{array}$ \\
\hline Waste Treatment & 3 & 17 & 2 & 1 \\
\hline Livestock & 2 & 0 & 0 & 0 \\
\hline Oil and Gas ....... & 9 & 1 & 0 & 0 \\
\hline Coal Mines . . . . . . . & 0 & 1 & 1 & 0 \\
\hline
\end{tabular}

Source: Energy Information Administration, Forms ElA1605 and EIA-1605EZ, "Voluntary Reporting of Greenhouse Gases" (1995 reporting cycle).

Other than the Wisconsin Electric Power project mentioned above, the largest of the projects reduced methane emissions by approximately 20,000 metric tons in 1994. There were two such projects, both occurring at landfills. The narrow range of reductions can be attributed in part to the absence of some of the Nation's largest landfill gas recovery facilities (in California and New York) and some of the Nation's most substantial coal mine degasification projects (in Alabama's Warrior Basin) from the reporting cohort.

Twenty-seven projects to reduce greenhouse gas emissions from waste treatment and disposal were reported by 11 separate entities. All but one recovered methane for use as an energy resource, and 25 of the 27 used the methane recovered to produce electricity. ${ }^{26}$ Twentyfour of the projects recovered methane from landfills, 2 recovered methane from wastewater treatment plants, and 1 reduced greenhouse gas emissions through the use of refuse-derived fuel.

Six of the landfill gas-to-energy projects reported, with a total claimed methane emissions reduction for 1994 of almost 60,000 metric tons, were associated with the U.S. Environmental Protection Agency's Landfill Methane Outreach program. Projects were undertaken in 16 States. Surprisingly, no projects were reported from California, a State with more than one-third of the Nation's landfill gas-to-energy installations. ${ }^{27}$

\footnotetext{
${ }^{26}$ The U.S. Environmental Protection Agency's Landfill Methane Outreach program estimates that more than 700 landfills could profitably recover and sell methane, most by using internal combustion engines to convert the methane to electricity. This estimate assumes renewal of the Section 29 tax credit for use of alternative fuels and continued favorable treatment of landfill gas as an alternative fuel by State public utility commissions.

${ }^{27}$ J. Pacey and S. Thorneloe, "Landfill Gas to Energy Database," presented at Solid Waste Association of North America's 18th Annual Landfill Gas Symposium (March 28-30, 1996).
} 


\section{Cinergy Corporation: Landfill Gas Recovery Projects}

Cinergy Corporation reported two landfill methane emissions reduction projects. The first, at the Danville, Indiana, landfill, reduces emissions by converting methane to electricity in a lean burn engine. The second, at Rumpke Landfill in Cincinnati, Ohio, reduces emissions by cleaning the landfill gas, upgrading it to pipeline quality, and adding it to Cinergy's natural gas transmission and distribution system. Both activities are described in Cinergy's Climate Challenge accord and have been undertaken in cooperation with the U.S. Environmental Protection Agency's Landfill Methane Outreach program.

Bio-Energy Partners, a subsidiary of Waste Management Incorporated, operates a 2-megawatt generation unit at the Danville, Indiana, landfill. Electricity generated at the unit is purchased by PSI Energy, a subsidiary of Cinergy. The electricity displaces generation from one of Cinergy's coal-fired electricity plants. Cinergy reported methane emissions reduc- tions from this project of about 700 metric tons during 1994 and, additionally, a net reduction in carbon dioxide emissions from displaced coal generation of approximately 700 metric tons. Cinergy has a contractual agreement with Bio-Energy Partners to be the sole reporter of the project.

At the Rumpke Landfill in Ohio, Cincinnati Gas and Electric (CC\&\&E), another Cinergy company, contracts with Air Products Incorporated under a long-term agreement to take recovered methane from the landfill, increase its heat value to pipeline quality (about 1,000 Btu per cubic foot), and provide it to CG\&E for placement into its gas distribution system. Cinergy reported that this project has reduced methane emissions by about 18,000 metric tons over each of the past 4 years, based on direct gas metering. As in Indiana, Cinergy has contractual rights to be the sole reporter of this project.
All but one of the reporters claiming reductions from landfill gas-to-energy projects were utilities that purchased electricity generated at landfills. The lone exception was Zahren Alternative Power Corporation (ZAPCO), a developer of landfill gas-to-energy projects that chronicled 10 separate projects. Both ZAPCO, the developer of the Hamm's Landfill in New Jersey, and General Public Utilities Corporation (GPU), the purchaser of electricity from that landfill, reported reductions achieved at the site. ZAPCO's reduction claim was about 20 percent higher $(2,298$ metric tons vs. 1,894 metric tons) and was calculated on the basis of measured gas volumes. In contrast, GPU back-calculated methane reductions on the basis of megawatthours purchased and an assumed heat rate. Because property rights have yet to be established for greenhouse gas emissions and reductions, and ZAPCO and GPU have not entered into a contractual relationship over the reductions, this duplicative reporting is not exceptional. Different emissions reduction estimates merely reflect data availability, estimation methods, and acceptable bounds of uncertainty for each reporter.

Two projects reported by GPU of Reading, Pennsylvania, claimed reductions in methane emissions from livestock. In one project, GPU purchased electricity from Valley Pork, Inc., in Seven Valleys, Pennsylvania. Valley Pork recovers methane from the waste its swine produce and uses it to generate electricity on site. GPU has contracted with Valley Pork to purchase any electricity generated in excess of on-site needs. More than
570,000 cubic feet of biogas were consumed for electricity generation purchased by GPU in 1991 and another 72,000 cubic feet in 1993. Methane emissions reductions reported for this project were just over 5 metric tons in 1991 and slightly under 1 metric ton in 1993.

GPU also reported a project to generate electricity from the waste of dairy cows, using an anaerobic digester at Mason Dixon Farms in Gettysburg, Pennsylvania. For this project, GPU reported emissions reductions for all methane used in electricity generation at the farm, not merely the electricity purchased. GPU reported electricity generation at the farm increasing from 945 to 1,200 megawatthours between 1991 and 1994. With an average heat content of $500 \mathrm{Btu}$ per cubic foot and a heat rate of 12,000 Btu per kilowatthour, the total estimated volume of biogas recovered ranged from 642,000 cubic meters in 1991 to 815,000 cubic meters in 1994. Assuming an average heat content of 500 Btu per cubic foot suggests that the biogas was about 50 percent methane; thus, overall methane emissions reductions equaled about 216 metric tons in 1991 and just under 300 metric tons in 1994.

In addition to reducing methane emissions, energy recovery projects may also reduce carbon dioxide emissions if the energy produced is displacing combustion of other fossil fuels. Of the energy recovery projects reported, seven reported reductions in both methane and carbon dioxide emissions, and three reported the reduction only in carbon dioxide emissions. 


\section{Northwest Fuelg}

Northwest Fuel Developinent retported on "Control

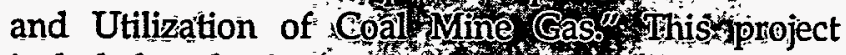
included coal mine methanerieconenyefforts at two mines.

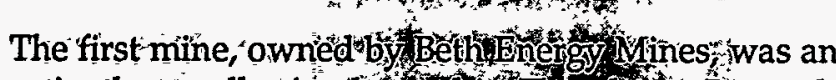

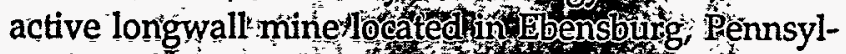
vania; whene methane open go but Ga Givecowered from the well was combusted in 150 kilon the mobile generating

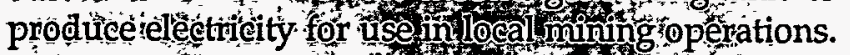
The unit operated for 500 hours th 1992 and 2,500 . hours in 1993, consuming 11 millon coubief feet of gas and producing a total of 450 megan a thours of electricity over 2 wears
At the Nelms mine in Gadin, Ohio, owned by Harrison Mining, Nonthwest Fuel Development controlled methane emissions from two open vents. One of the vents has had a femporary cap installed, which Northwest claims prevents over 5 million cubic feet (29 mefric tons) of methane emissions per day At the

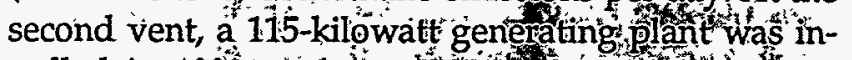
stalled in 199,3 and an aditional 150 kilowatts of capacity was installed in ind inger. The electricity generated was solet to American Electric Power's Ohio Power Company unit, where it displaced other fossil fuel generation and thus reduced carbon dioxide emissions. Together, more,than 11,400 metric tons of methane emissions were avoided at the two mine sites during 1994.
There were 11 projects reported that reduced emissions from the U.S. oil and natural gas system. Five were reported by Brooklyn Union Gas on the short form. While these projects had modest reductions-ranging from 7 to 85 metric tons-they offer a fair sampling of the many opportunities to reduce methane emissions from the oil and natural gas system. As a participant in the EPA's Natural Gas Star program, Brooklyn Union improved the directed inspection and maintenance of its surface and subsurface facilities, replaced leaky pipeline, installed new gas regulators at gate stations, reduced flaring when retiring gas holders, and reduced venting from controllers at gate stations.

One project reported by Western Resources Incorporated reduced methane emissions by more than 5,000 metric tons in 1994 by replacing leaking pipelines. A sense of the opportunity for significant reductions in this area can be gained by examining the project reported by NIPSCO Industries. By replacing just 6 miles of the North Trenton pipeline, NIPSCO eliminated 320 metric tons of annual emissions.

There were just two projects reported that reduced methane emissions from coal mines, but each resulted in substantial emissions reductions. The projects were reported by Peabody Holding Company and Northwest Fuel Development Corporation. Peabody's project, associated with the EPA's Coalbed Methane Outreach program, recovered methane from gob wells at the Federal II mine in Fairview, West Virginia. The Federal II mine is a longwall mine typically producing in excess of 3 million short tons of coal annually. In 1994, Peabody recovered more than 120 million cubic feet of pipeline-quality gas from the mine, reducing methane emissions by some 2,300 metric tons. Northwest Fuel
Development reported emissions reductions at two mines, an operating mine in Ebensburg, Pennsylvania, and a sealed mine in Cadiz, Ohio. Northwest captured more than 600 million cubic feet of gas from these mines in 1994, with an average heat content of $950 \mathrm{Btu}$ per cubic foot. This was equivalent to a reduction in methane emissions of approximately 11,400 metric tons, or more than 76,000 metric tons carbon equivalent. Combined, these two projects reduced methane emissions by just under 14,000 metric tons in 1994, more than double the amount saved (approximately 6,100 metric tons) by the 11 oil and natural gas system projects (Figure 14).

Figure 14. Reported Methane Emissions Reductions by Project Type

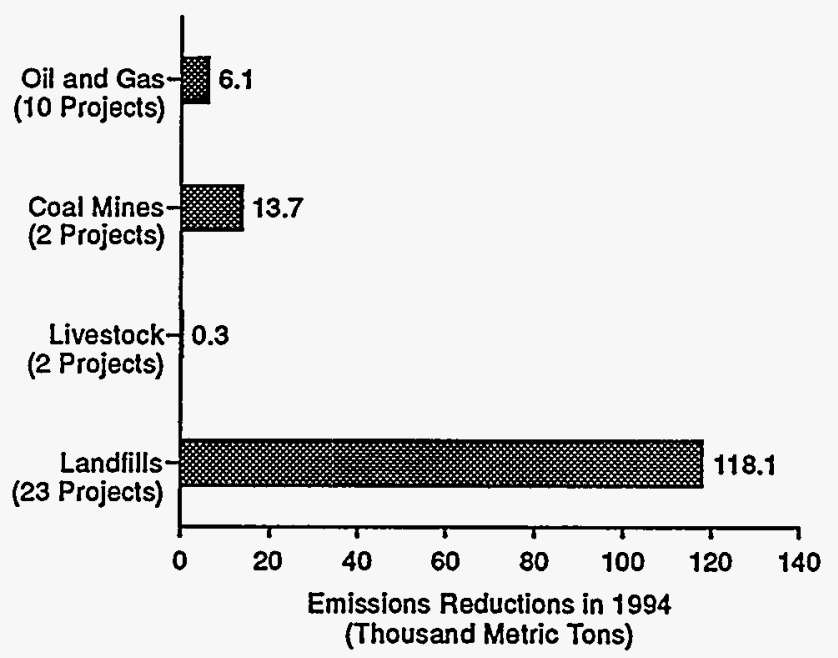

Source: Energy Information Administration, Forms EIA-1605 and EIA-1605EZ, "Voluntary Reporting of Greenhouse Gases" (1995 reporting cycle). 


\section{Forestry-Related Carbon Sequestration and Carbon Dioxide Emissions Reductions}

\section{Background}

Carbon sequestration plays an important role in reducing accumulated carbon dioxide in the atmosphere. Green plants remove (sequester) carbon from the atmosphere by way of photosynthesis. Growing plants extract carbon dioxide from the atmosphere, separate the carbon atom from the oxygen atoms, return oxygen to the atmosphere, and use the carbon to make biomass in the form of roots, stems, and foliage.

Every year in the United States and throughout the world a very large amount of carbon dioxide is sequestered into biomass, on the order of 100 billion metric tons. ${ }^{28}$ At the same time, carbon is released to the atmosphere from vegetative respiration, combustion of wood as fuel, degradation of manufactured wood products, and the natural decay of expired vegetation. The net numerical difference, or flux, between carbon sequestration and release can be viewed as a measure of the relative contribution of biomass to the carbon cycle. World flux is difficult to measure, but it is thought to be a net "sink" of carbon dioxide.

In the United States, however, all forests combined and the wood products produced from them sequestered a net of approximately 451 million metric tons of carbon dioxide in $1994 .^{29}$ For comparison, this quantity is equal to approximately 9 percent of the 5,248 million metric tons of carbon dioxide emitted in the United States in 1994 from the burning of fossil fuels, and could be said to have offset that amount. ${ }^{30}$

The amount of carbon a plant can sequester depends on a number of variables including species and age, but can be quite large. For example, one large sugar maple tree is capable of removing more than 450 pounds of carbon dioxide from the atmosphere in one year. At that rate, preserving 5 trees per operating automobile in the U.S. would offset 20 percent of U.S. automobilerelated carbon dioxide emissions. ${ }^{31}$

\section{Projects Reported}

A total of 40 entities reported forestry-related carbon sequestration or emissions reduction projects. Almost all ( 90 percent) of those entities are also participants in the Climate Challenge program. There were 78 carbon sequestration projects reported (12.1 percent of all projects). The reported total amount of carbon dioxide sequestered by these projects in the period 1991-1994 was 2.19 million metric tons. ${ }^{32}$ Of the sequestration projects undertaken, 70 (90 percent) were undertaken by electric utilities.

The types of forestry-related carbon sequestration and emissions reduction projects reported in 1995 included a wide range of tree planting and forest management activities, as well as conservation tillage and investment programs. Table 17 lists the project types and the frequency of their reporting. Many of the reported projects

\section{Table 17. Reported Carbon Sequestration Projects by Project Type}

\begin{tabular}{|c|c|}
\hline Project Type & Number Reported \\
\hline Afforestation $\ldots \ldots \ldots \ldots \ldots$ & 33 \\
\hline Reforestation $\ldots \ldots \ldots \ldots \ldots$ & 15 \\
\hline Urban Forestry $\ldots \ldots \ldots \ldots \ldots$ & 20 \\
\hline Modified Forest Management ... . & 12 \\
\hline Agroforestry $\ldots \ldots \ldots \ldots \ldots$ & 7 \\
\hline Forest Preservation . . . . . . . . & 1 \\
\hline Conservation Tillage $\ldots \ldots \ldots \ldots$ & 1 \\
\hline Other Projects $\ldots \ldots \ldots \ldots \ldots$ & 4 \\
\hline
\end{tabular}

Note: Some projects may be counted in more than one category.

Source: Energy Information Administration, Forms EIA1605 and EIA-1605EZ, "Voluntary Reporting of Greenhouse Gases" (1995 reporting cycle).

\footnotetext{
${ }^{28}$ Intergovernmental Panel on Climate Change, Greenhouse Gas Inventory Reference Manual, IPCC Guidelines for National Greenhouse Gas Inventories, Vol. 3 (Paris, France, 1995), p. 5.2.

${ }^{29}$ R.A Birdsey and L.S. Heath, "Carbon Changes in U.S. Forests," in L.A. Joyce (ed.), Productivity of America's Forests and Climate Change (Fort Collins, CO: USDA Forest Service, 1995).

${ }^{30}$ Energy Information Administration, Emissions of Greenhouse Gases in the United States 1987-1994, DOE/EIA-0573(87-94) (Washington, DC, October 1995), Chapter 2.

${ }^{31}$ Number of automobiles in operation in 1993, automobile miles traveled, and average miles per gallon from Energy Information Administration, Annual Energy Review 1994, DOE/EIA-0384(94) (Washington, DC, July 1995), pp. 67, 69. Carbon dioxide emissions per gallon of motor gasoline from U.S. Department of Energy, Sector-Specific Issues and Reporting Methodologies Supporting the General Guidelines for the Voluntary Reporting of Greenhouse Gases Under Section 1605(b) of the Energy Policy Act of 1992, DOE/PO-0028 (Washington, DC October 1994), Vol. 2, p. 4.19.

${ }^{32}$ Reported estimates of carbon sequestration and emissions reductions may not be strictly comparable across projects. Participants employed a wide range of estimation methods in determining the effects of their projects. The underlying database records reported methodologies.
} 


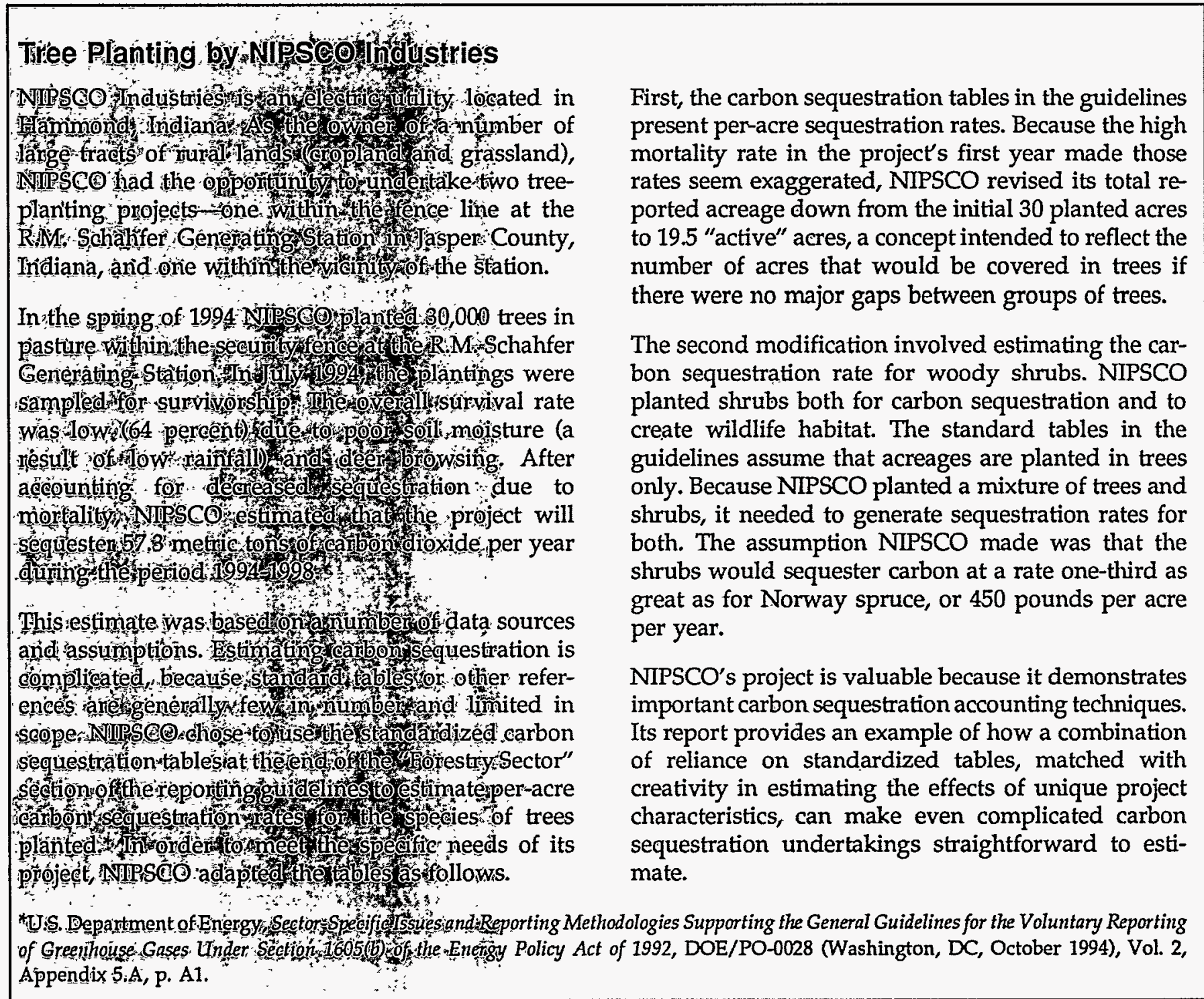

involved more than one project type-for example, both afforestation and reforestation. The project types are defined as follows:

- Afforestation is the planting of trees in areas absent of trees in recent times. An example would be planting trees on abandoned farmland.

- Reforestation is the planting of trees where trees had recently been before, but currently are absent. An example would be reforesting a site where 100 acres of forest had been cleared 2 years earlier.

- Urban Forestry is the planting of trees in urban or suburban settings, along streets, in yards, and in parks. The carbon dioxide benefits from urban forestry can be of two types: carbon directly sequestered into living trees, and reduction of carbon emissions from electric utilities as a result of decreased end-use energy consumption for cooling and heating.

- Forest Preservation is the maintenance and augmentation of carbon sinks through the preservation of existing forest biomass. All forests are net carbon accumulators if preserved (except when large fires occur). The effect of carbon release due to tree mortality is more than offset by the accumulation of carbon in forest soils. U.S. Forest Service researcher Richard Birdsey estimated that 59 percent of all carbon stored in U.S. forests is located in the soil. ${ }^{33}$

${ }^{33}$ R.A. Birdsey, Carbon Storage and Accumulation in United States Forest Ecosystems, U.S. Forest Service General Technical Report WO-59 (Washington, DC, 1992), p. 3. 


\section{Trees for the Future: International Agroforestry}

Trees for the Future (TFF) is a nonprofit organization located in Silver Spring, Maryland. Its purpose is to support organizations that plant trees overseas while educating the American public about the economic, environmental, and social consequences of deforestation. In its submission, TFF reported on seven carbon sequestration projects undertaken in Belize, Cameroon, Ghana, Guatemala, Honduras, India, and Nepal during the years 1991-1994. One of the projects, an agroforestry project in Cameroon, was reported to have sequestered a total of 409,542 metric tons of carbon dioxide in the period 1991-1994.

The northwest Province of Cameroon has been almost completely deforested over the past 50 years. Lack of forest cover has caused hardship for local farming communities because of soil erosion, declining food crops, and falling water tables. Beginning in late 1990, a women's association in the village of Lun requested assistance from TFF for the planting of fast-growing, permanent trees to restore water supplies to the village. Early results encouraged community leaders to expand the program into 158 villages by the end of 1991, with more than 3,000 families participating. Local, cooperatively managed seedling nurseries were established, and the resulting trees were distributed throughout the communities.

A local organization, Trees for the Future of Cameroon, has been established. Through this organization, seed production facilities and demonstration farms have been established throughout the Province. Affiliated organizations have started major plantings in the towns of N'Dop and Jakiri. By mid-1994, more than 7,200 families were participating in the program, and a new training center was being established in Bamenda.

Tree species planted include Leucaena leucocephala type K-67, Albizia julibrisin rosea, Calliandra calothrysus, Paegeum africanus, and Gmelina arborea. The trees will be sustainably harvested for livestock forage and organic fertilizer, wood poles, posts and banana props, and marketable medicinal products. A total of 1,389,000 trees were planted between 1991 and 1993. The total land area included in this project was 834 hectares (2,061 acres). The planned harvest age is 25 years, and all acres will be replanted immediately following harvèst.

TFF calculated the average sequestration rate per tree to be 57.0 pounds of carbon dioxide per year. It would take 35 trees sequestering carbon dioxide at this rate 1 year to sequester approximately 1 metric ton of carbon dioxide. The calculations of total sequestration are based on the total quantity of carbon sequestered into living biomass over the 25-year period (842,055 metric tons of carbon dioxide), plus all carbon added to the soil over the 25-year period (152,997 metric tons of carbon dioxide). The report contains a detailed analysis of each component of these calculations, including the root-branch multiplier, wood density, carbon content, change in organic matter, and depth of topsoil. TFF estimates that carbon sequestration costs approximately $\$ 4.00$ per ton of carbon dioxide removed from the atmosphere.**

*Calculations based on M.C. Trexler, P.E. Faeth, and J.M. Kramer, Forestry Response to Global Warming: An Analysis of the Guatemala Agroforestry and Carbon Sequestration Project (Washington, DC: World Resources Institute, 1989), 68 pp; and P. Faeth, C. Cort, and R. Livernash, Exaluating the Carbon Sequestration Benefits of Foresiry Projects in Developing Countries (Washington, DC: World Resources Institute, 1994), $96 \mathrm{pp}$.

** Trees for the Future, "Proposed Program Goals and Budget-1995" (Silver Spring, MD, 1995), p. 5.

- Modified Forest Management encompasses a range of management options that reduce carbon release from forests. For example, reduced impact logging that leaves more trees standing after harvest than conventional methods is one technique to reduce carbon emissions from forestry.

- Agroforestry is the practice of planting and managing trees in conjunction with agricultural crops. For example, fruit trees could be incorporated in fields that previously contained only one or more row crops, thereby increasing the per-acre rate of carbon sequestration.
- Conservation Tillage is the practice of leaving sufficient crop residue on the soil surface after harvests to prevent soil erosion. Conservation tillage also results in net additions to soil carbon due to the gradual incorporation of organic matter into the soil.

Information on the number of trees planted and number of acres affected exists only on a project-byproject basis; totals for all projects are not available. Some entities reported total acreage affected but excluded estimates of the number of trees planted. Other entities reported the number of trees planted but 
not the extent of the acreage affected. There was no method common to a majority of reporters, and it is not possible to calculate totals or averages for all projects.

Emissions reductions were another reported aspect of carbon sequestration projects. Emissions reductions can result from activities such as reduced impact logging, reduction of nitrogen fertilization after harvest, and more fuel-efficient harvesting machinery. Reported emissions reductions associated with forestry activities amounted to 32,006 metric tons of carbon dioxide in the period 1991-1994. Table 18 summarizes reported sequestration and reductions over this period. Projects were undertaken in at least 24 States and 9 foreign countries (Table 19). One entity, Trees for the Future, accounted for 7 of the international projects.

\section{Halogenated Substances}

\section{Background}

Halogenated substances are human-made chemical compounds. They are useful in a number of industrial and commercial applications because they are inert and, thus, nontoxic. However, because these compounds do not occur in nature, they absorb infrared radiation at wavelengths at which the atmosphere is otherwise transparent. Also, because they are nearly inert, they do not break down rapidly in the atmosphere and therefore have long atmospheric lifetimes. Thus, halogenated substances have potentially large effects on global climate. Their direct global warming potential may be as much as 12,000 times that of carbon dioxide. ${ }^{34}$

The halogenated substances include chlorofluorocarbons (CFCs), hydrochlorofluorocarbons (HCFCs), bro-
Table 19. Location of Forestry Projects

\begin{tabular}{ll}
\hline \multicolumn{1}{c}{ Domestic } & International \\
\hline Alabama & Belize \\
California & Cameroon \\
Delaware & Ghana \\
Florida & Guatemala \\
Georgia & Honduras \\
lowa & India \\
Indiana & Malaysia \\
Kentucky & Nepal \\
Louisiana & Russia \\
Minnesota & \\
Mississippi & \\
Missouri & \\
Nebraska & \\
North Carolina & \\
Ohio & \\
Oklahoma & \\
Oregon & \\
Pennsylvania & \\
South Carolina & \\
Tennesseo & \\
Texas & \\
Utah & \\
Washington & \\
Wisconsin & \\
\hline
\end{tabular}

Source: Energy Information Administration, Forms ElA1605 and EIA-1605EZ, "Voluntary Reporting of Greenhouse Gases" (1995 reporting cycle).

mofluorocarbons (halons), hydrofluorocarbons (HFCs), and perfluorocarbons (PFCs). They have a wide array of everyday uses, such as halon in fire extinguishers, HCFC-22 in residential air conditioners, and HFC-134a in automobile air conditioners. Formerly, CFC-12

Table 18. Reported Carbon Sequestration and Emissions Reductions, 1991-1994 (Metric Tons of Carbon)

\begin{tabular}{|c|c|c|c|c|c|}
\hline Data Reported & 1991 & 1992 & 1993 & 1994 & Total \\
\hline Carbon Sequestration & 142,297 & 571,134 & 709,271 & 772,130 & $2,194,832$ \\
\hline Percent of 1991-1994 Total . . . . . . . . . & $6.5 \%$ & $26.0 \%$ & $32.3 \%$ & $35.2 \%$ & $100.0 \%$ \\
\hline Carbon Emissions Reduction . . . . . . . . . . & 0 & 0 & 8,690 & 23,316 & 32,006 \\
\hline Percent of 1991-1994 Total . . . . . . . . . . & $0.0 \%$ & $0.0 \%$ & $27.2 \%$ & $72.8 \%$ & $100.0 \%$ \\
\hline Total Sequestration and Reductions & 142,297 & 571,134 & 717,961 & 795,446 & $2,226,838$ \\
\hline
\end{tabular}

Note: All numbers shown are based on estimates of project effects by participants in the Voluntary Reporting Program, and may or may not accurately reflect actual sequestration or reductions.

Source: Energy Information Administration, Forms EIA-1605 and EIA-1605EZ, "Voluntary Reporting of Greenhouse Gases" (1995 reporting cycle).

${ }^{34}$ D.L. Albritton et al., "Trace Gas Radiative Forcing Indices," in J.T. Houghton et al., Climate Change 1994 (Cambridge, UK: Cambridge University Press, 1995), p. 222. 
(commonly known as "freon") was used in almost all automobile air conditioners; however, CFC-12 has been implicated in the destruction of stratospheric ozone that protects humans, flora, and fauna from harmful ultraviolet radiation. In response to this serious environmental hazard, the production and use of CFCs is being phased out under a series of international agreementsthe Montreal Protocol, London Agreement, and Copenhagen Agreement. In the United States, those agreements are being implemented through the Clean Air Act Amendments of 1990, which call for CFC production in the United States to cease by December 31, 1996.5 Thus, HFC-134a is now widely used in automobile air conditioners.

Stratospheric ozone is a naturally occurring greenhouse gas. Because CFCs, and to some extent HCFCs, deplete stratospheric ozone, they also have an indirect cooling effect on global climate, offsetting their direct heat trapping capacity. Thus, their overall effect on global climate is difficult to discern and likely to be less dramatic than the effect of other halogenated substances.

Estimated emissions of CFC-11, CFC-12, and CFC-113 declined by 38 percent, 34 percent, and 56 percent, respectively, between 1990 and 1994 as production was phased out pursuant to the Montreal Protocol and Clean Air Act Amendments. Meanwhile, estimated emissions of HCFCs, temporary substitutes for CFCs, increased by more than 60 percent during the same time frame. HCFC emissions grew from 84,000 metric tons in 1990 to 135,000 in 1994 . This 51,000 metric ton increase was about one-half of the 106,000 metric ton decrease in CFC emissions. Over the same time period, emissions of HFC-134a have expanded tenfold. ${ }^{36}$ The expansion in emissions of CFC substitutes presents problems. While they have less severe effects on stratospheric ozone, they do have strong heat-trapping effects which, with extended use, may pose serious problems from a global climate perspective.

Unlike most halogenated substances, perfluoromethane and perfluoroethane, commonly described as PFCs, are not produced for sale but rather are byproducts of the aluminum smelting process. They have a very high heat-trapping capacity. Reducing emissions of perfluoroethane by 1 ton is equivalent to eliminating 12,500 tons of carbon dioxide. ${ }^{37}$ The EPA has sought to encourage aluminum companies to take steps to reduce
PFC emissions through its Voluntary Aluminum Industrial Partnership program.

\section{Projects Reported}

A total of 15 projects to reduce emissions of halogenated substances were reported by 13 entities. Detailed information was provided for 13 (87 percent) of the projects on the long form, and summary data for 2 projects were reported by the Salt River Project on the short form. The projects reported fell into four main areas: appliance roundup and recycling ( 7 projects, or 47 percent); replacement or substitution of compounds (3 projects, or 20 percent); improved operations and maintenance ( 3 projects); and reductions in PFC emissions from aluminum smelting ( 2 projects).

The reported appliance roundup and recycling projects reduced emissions of CFC-12 in 1994 by more than 38.5 metric tons. Reductions of CFC-12 ranged from less than 500 pounds for one project to more than 26 metric tons for the largest reported project. Roundup and recycling projects also reported reducing emissions of CFC-11 and HCFC-22 by two metric tons and one metric ton, respectively, in 1994.

The substitution or replacement of halogenated substances yielded reported reductions of almost 2 metric tons for CFC-11 and just under 1 metric ton for CFC-12 in 1994, and changes in operations and maintenance procedures during 1994 reduced emissions of six different compounds. The largest reduction reported for a change in operations and maintenance took place at General Public Utilities transmission and distribution facilities, where 4 metric tons of sulfur hexafluoride emissions were avoided, equivalent to 66,000 metric tons of carbon dioxide. The Tennessee Valley Authority reduced emissions of CFC-12, CFC-113, HCFC-22, and CFC-502 by $1,500,59,92$, and 1,050 pounds, respectively, in 1994 through improved CFC management but concurrently increased emissions of HCFC-123 and HFC-134a (CFC replacements with less destructive effects on ozone) by 50 pounds each.

Noranda Aluminum of Missouri and Alcan Ingot in Kentucky each reported a project to reduce fugitive emissions of PFCs as a byproduct of the aluminum production process. Both projects were undertaken in cooperation with the EPA's Voluntary Aluminum Industrial Partnership. The reductions in emissions of

\footnotetext{
${ }^{35}$ Energy Information Administration, Emissions of Greenhouse Gases in the United States 1987-1994, DOE/EIA-0573(87-94) (Washington, DC, October 1995), p. 51.

${ }^{36}$ Energy Information Administration, Emissions of Greenhouse Gases in the United States 1987-1994, DOE/EIA-0573(87-94) (Washington, DC, October 1995), p. 54.

${ }^{37}$ D.L. Albritton et al., "Trace Gas Radiative Forcing Indices," in J.T. Houghton et al., Climate Change 1994 (Cambridge, UK: Cambridge University Press, 1995), p. 222.
} 


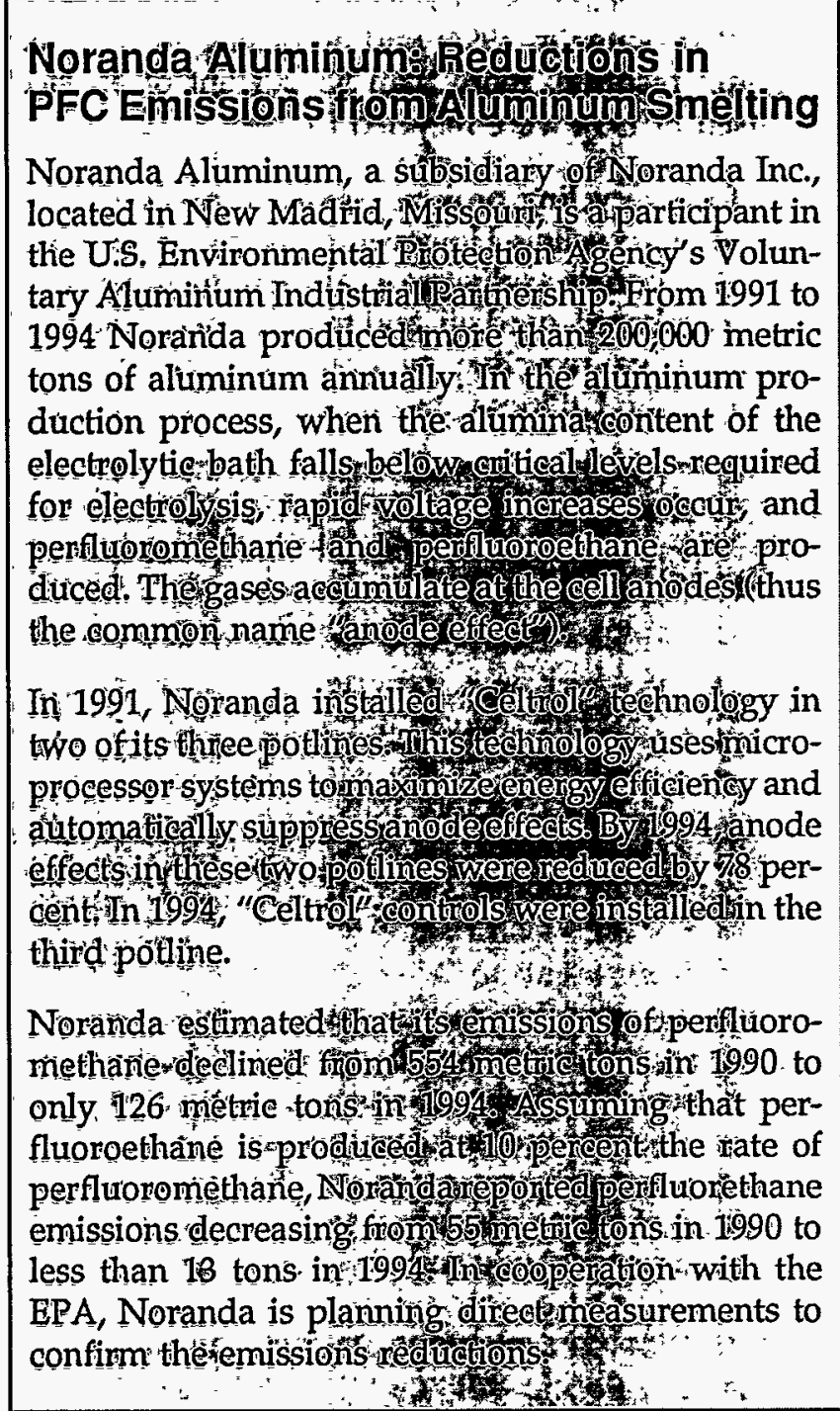

perfluoromethane and perfluorethane reported by aluminum manufacturers dwarfed reductions of all other gases reported in this section, both in native units and in carbon equivalent. Together, Noranda and Alcan Ingot avoided 465 metric tons of perfluoromethane emissions and 46.5 metric tons of perfluorethane emissions during 1994.

\section{Other Emissions Reduction Projects}

\section{Background}

Projects reported during the first reporting cycle of the Voluntary Reporting Program included activities that did not fit any of the preceding project categories. These projects included recycling of coal ash and other materials, such as paper, wood, cardboard, aluminum, iron, and steel, as well as public education and employee training efforts.

\section{Projects Reported}

Thirty-three entities reported a total of 38 projects under the category of "other emissions reduction projects" during the first year of the program. All reporting entities in this project category were electric utilities. Thirty-seven projects were carried out as part of Climate Challenge efforts. One paper recycling project that was part of the Waste Wise program was also reported.

Of these 38 projects, 22 involved recycling coal ash. Ten projects reported on recycling materials, such as paper, wood, cardboard, aluminum, iron, and steel. Three projects focused on public education and employee training, and three other miscellaneous projects were reported. In 1994, these projects collectively achieved 0.5 million metric tons of direct and 2.1 million metric tons of indirect carbon dioxide emissions reductions (Table 20).

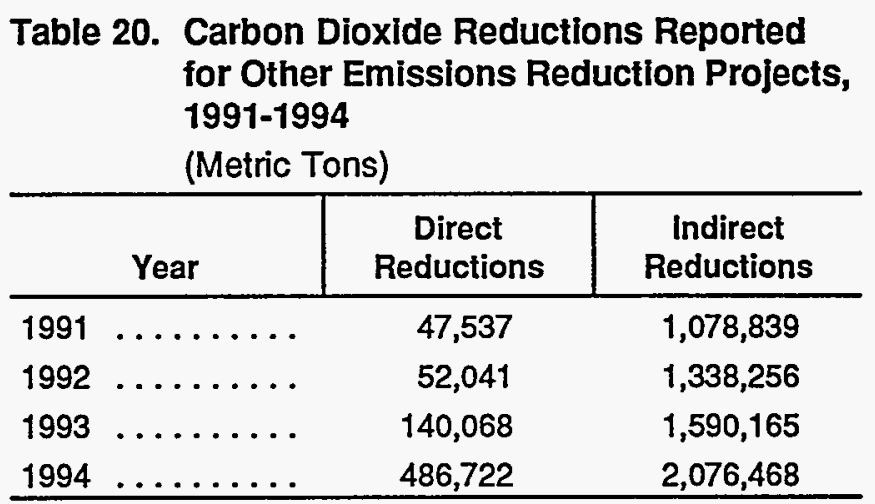

Source: Energy Information Administration, Forms EIA1605 and ElA-1605EZ, "Voluntary Reporting of Greenhouse Gases" (1995 reporting cycle).

\section{Coal Ash}

Utility coal ash has presented a disposal burden in the face of rising landfill disposal costs and more stringent environmental regulations. Increasingly, however, utility coal ash is becoming a valuable resource as the market for this byproduct expands to include applications as diverse as manufacturing tennis rackets and floor tiles. According to the American Coal Ash Association, only 20 percent of the 82 million tons of coal ash produced by utilities in 1992 was recycled. ${ }^{38}$

\footnotetext{
${ }^{38}$ P. Harris, "Utilities Find New Uses for Coal Byproducts," Environment Today, Vol. 5, No. 2 ( February 1994 ), p. 1.
} 
The 22 reported coal ash projects focused on the more conventional uses for fly ash, a coal combustion byproduct, as a replacement for cement in concrete. This use reduces the amount of cement required to manufacture concrete, with a concomitant reduction in carbon dioxide emissions. ${ }^{39}$ Use of one ton of coal ash as replacement is estimated to reduce carbon dioxide emissions by approximately 0.8 metric tons. ${ }^{40}$ This figure may vary, however, as fossil fuel requirements per ton of cement differ for various kilns and processes.

The most frequently used emissions reduction coefficient in the reported projects was 1 ton of carbon dioxide per ton of recycled coal ash. For 1994, the largest carbon dioxide emissions reduction associated with a fly ash utilization project was reported by American Electric Power of Columbus, Ohio. This utility sold 482,121 metric tons of fly ash for replacement in cement, resulting in the equivalent reduction in carbon dioxide emissions. For the 1991-1994 reporting period, fly ash utilization projects avoided a total of 5.6 million metric tons of carbon dioxide emissions (Table 21).

\section{Table 21. Carbon Dioxide Emissions Reductions Reported for Coal Ash Utilization Projects, 1991-1994 (Metric Tons)}

\begin{tabular}{ccc}
\hline \multicolumn{2}{c|}{ Year } & Reductions \\
\hline $1991 \ldots \ldots \ldots \ldots \ldots \ldots \ldots \ldots$ & $1,019,269$ \\
$1992 \ldots \ldots \ldots \ldots \ldots \ldots \ldots$ & $1,284,675$ \\
$1993 \ldots \ldots \ldots \ldots \ldots \ldots \ldots$ & $1,514,975$ \\
$1994 \ldots \ldots \ldots \ldots \ldots \ldots$ & $1,776,625$ \\
\hline
\end{tabular}

Source: Energy Information Administration, Forms EIA1605 and ElA-1605EZ, "Voluntary Reporting of Greenhouse Gases" (1995 reporting cycle).

\section{Recycling Paper, Aluminum, Iron, and Steel}

Recycling materials, in some cases, not only requires less energy than the production of virgin materials but also provides environmental benefits from the conservation of resources. The national recycling rate, estimated at 17 percent in 1990, is now estimated to be near 25 percent. ${ }^{41}$ Collections have increased significantly for the paper industry. ${ }^{42}$ According to Alcan, consumers returned 65 percent of all aluminum cans produced in the United States in 1994; and according to the Steel Recycling Institute, more than 53 percent of all steel cans used in 1994 were recycled in 1994. ${ }^{43}$

Most of the recycling projects reported involved office paper waste recycling. However, recycling projects also included materials as diverse as aluminum, other scrap metals, cardboard, used oil, and transformers. The most comprehensive recycling program was reported by General Public Utilities Corporation (see box below).

\section{General Public Utilities Corporation's Recycling Program}

General Public Utilities Corporation (GPU) of Reading, Pennsylvania, reported on its extensive recycling program, which includes scrap metals, such as aluminum, brass, copper, iron, nickel, mercury, and steel; meters, both for reuse and scrap metal; paper; cardboard; construction debris; asphalt and cement; containers for reuse; transformers; transformer oil; wood pallets for reuse; wood reels; treated wood sent to a waste-to-energy facility; untreated wood for mulch; motor oil; solvents/ degreasers; antifreeze; and batteries. GPU estimated carbon dioxide emissions reductions associated with its recycling of aluminum, iron and steel, paper, and treated wood. Over the period 1991-1994, GPU's recycling efforts resulted in a total of 71,635 metric tons of carbon dioxide emissions reductions.

Carbon Dioxide Emissions Reductions.Reported for General Public Utilities Corporation's Recycling Program, 1991-1994

(Metric Tons)

\begin{tabular}{cc}
\hline \multicolumn{1}{c|}{ Vear } & Reductions \\
\hline $1991 \ldots \ldots \ldots \ldots$ & 18,483 \\
$1992 \ldots \ldots \ldots \ldots$ & 18,629 \\
$1993 \ldots \ldots \ldots$ & 18,032 \\
$1994 \ldots \ldots \ldots$ & 16,491 \\
\hline
\end{tabular}

Source: Energy Information Administration, Form ElA1605, "Voluntary Reporting of Greenhouse Gases" (1995 reporting cycle).

\footnotetext{
${ }^{39} \mathrm{D}$. Klein and S. Tyson, "Climate Change and New Opportunities for Coal Combustion Byproducts," presented at the Eleventh Symposium on the Uses and Management of Coal Combustion Byproducts (Orlando, FL, January 1995).

${ }^{40} 1.2$ tons of coal ash can replace 1.0 ton of cement, which releases 0.95 tons of carbon dioxide, about half from the calcination process and half from the combustion of fossil fuel (i.e., 1.0 ton of cement divided by 1.2 tons of coal ash equals 0.833 tons of cement, and 0.833 multiplied by 0.95 metric tons of carbon dioxide equals 0.797 , or about 0.8 metric tons of carbon dioxide per ton of recycled coal ash).

${ }^{41}$ R. Steutevill, "Year End Review of Recycling," Biocycle, Vol. 35, No. 12 (December 1994), p. 31.

${ }^{42}$ R. Steutevill, "Year End Review of Recycling," Biocycle, Vol. 35, No. 12 (December 1994), p. 31.

43"Steel- and Aluminum-Can Recycling Increased in 1994," Iron Age, Vol. 11, No. 5 (1995), p. 15.
} 


\section{Public Education and Employee Tralning}

Three reporters cited projects involving public education or employee training: The City of Wayne (Nebraska), NIPSCO Industries (Hammond, Indiana), and Central Illinois Light Company (CILCO, Peoria, Illinois). NIPSCO Industries reported providing training for more than 7,800 student days to educate its work force on ways to reduce greenhouse gas emissions. Subjects included proper gas burner adjustments for ranges, hot water heaters, and furnaces; operation and calibration of carbon monoxide detectors; techniques to investigate presence of halogenated hydrocarbons that could damage heating equipment; welding procedures for repairing gas lines; procedures for installing natural gas fuel equipment on company vehicles; and techniques for identifying leaks at gas meters.

Since 1992, CILCO has engaged in a public education initiative to promote energy efficiency in the home. Company instructors visit public elementary and high schools and community events to work with customers to address electricity waste. Annual energy savings from reduced lighting, thermostat setbacks, shorter showers, hanging clothes to dry, water heater wraps, and other measures are estimated at 274.2 kilowatthours per participant. For 1994, CILCO estimated savings of 3.0 million kilowatthours resulting from the program and carbon dioxide emissions reductions of 3,094 metric tons. 



\section{Emissions Accounting Issues}

\section{Introduction}

The Department of Energy's guidelines for the Voluntary Reporting Program generally took the view that it was for reporters themselves to define the emissions and reductions for which they felt themselves responsible. However, it was the task of the Energy Information Administration (EIA) to develop a reporting system in which these possibly diverse definitions could be made clear to data users. In attempting to achieve this objective, the EIA was able to identify a number of emissions accounting issues that presented significant problems in understanding and interpreting the data.

This chapter discusses several important issues in the development of the forms and the review of incoming reports. This work may assist data users in understanding the uses and limitations of data from the Voluntary Reporting Program.

\section{The Nature of the Entity}

As noted above, there are different views about the nature of the entity, and reporters have adopted various conventions. In general, the most common definition of the entity is a corporation. However, reporters have made a number of modifications to this concept; for example, General Motors excluded its overseas operations and its interest in Electronic Data Systems (EDS) from its definition of its corporate entity. Most electric utilities defined their entities as their regulated utility activities, excluding unrelated activities owned by their holding companies. Houston Light \& Power excluded the activities of its parent company, Houston Industries, which included a cable TV operation.

Not all entities are firms. Several reporters are facilities, notably, Alcan's Sebree Aluminum Plant, which reduced emissions of perfluorocarbons. Several firms reported projects which they undertook on behalf of some other organization, such as landfill methane capture or tree planting, where the owner of the project was not necessarily the reporter. This led to several instances of multiple reporting.

\section{Types of Reports}

The language of the statute calls for "annual reductions of greenhouse gas emissions ... achieved through any measures ..." (1605(b)(1)(B)), and separately calls for "an aggregate calculation of greenhouse gas emissions by each reporting entity." As interpreted in the guidelines and in the forms, it establishes two categories of reporting of emissions reduction:

- In an "entity-wide" report, the emissions reported are the emissions of the entire entity: for example, the total emissions of a particular electric utility. The emissions of the entity can rise or fall. Some firms (9) did not report emissions reductions: they simply reported emissions.

- In a "project report," the reporter indicates the results of certain specified actions taken (called "projects") that resulted in a reduction of emissions of greenhouse gases (or increased sequestration). Most firms that filed entity-wide reports also filed one or more reports on projects.

\section{Emissions and Reductions}

The distinction between reporting emissions and reporting emissions reductions is fundamental to the Voluntary Reporting Program. The program, following the language of the statute, asks for both emissions and reductions. At the entity level, the definition of emissions is relatively straightforward. At the project level, however, the definition of emissions and reductions can be intricate. The fundamental problem is that the project may only be a piece of a larger system, and it is not clear whether "emissions and reductions" refer to the emissions of the part or the emissions of the whole system. In some cases, the project may not have meaningful emissions at all.

For example, large electric utilities (and many reporters are such) will have multiple power generation plants which are used, as a group, to generate electricity. Since electricity consumption varies from second to seconddepending on the season, weather, time of day, and whims of thousands or millions of customers-utilities 
operate dispatch centers that continually choose the least-cost generation mix to actually dispatch at a particular moment in time. At any given time, some plants may be on "spinning reserve," some are generating power, others may be on standby, and others may be shut down for maintenance. All available generation units are ranked by "merit order" (some combination of short-run marginal cost and operational considerations) and are used in order of increasing "merit," with the lowest cost units used first, subject to availability. Momentary surpluses of electricity may be sold to others, and shortages may be made up by purchases from others.

Suppose a large utility repowers an old, low-efficiency fossil plant with a new, high-efficiency plant. In principle, the new plant could affect the usage (and hence emissions) of every other plant on the utility's system, and even on other utility systems, since the new unit will "bump" all higher cost units in the merit order.

Thus, the relevant emissions that are being reduced by the project are the emissions of the entire system, and the actual emissions of the repowered plant may be much higher than the emissions of the old unit. Since the old unit was a high-cost unit, it may have been used only occasionally. The new unit, with low costs, will be dispatched frequently, and will displace the emissions, not of the unit it replaced, but of other units with costs greater than the new unit but lower than the old unit.

The Tennessee Valley Authority (TVA), for example, defined its "emissions" for most of its power generation and end-use projects as all of TVA's power generation emissions, more than 10 million metric tons of carbon dioxide. Other utilities defined their emissions as the emissions of a particular plant. While both definitions are reasonable, they are not comparable.

\section{Direct and Indirect Emissions and Reductions}

One of the more contentious issues that emerged in the process of developing the guidelines was the question of defining exactly who was responsible for particular emissions. Suppose, for example, in response to an Environmental Protection Agency initiative, that a refrigerator manufacturer designs and builds an energyefficient refrigerator with performance that far exceeds that of other refrigerators on the market. An electric utility then offers rebates to customers if they purchase the energy-efficient refrigerator. Customers buy the refrigerator and accept the rebate. The customer purchases less electricity, and the electric utility generates (or purchases) less electricity from fossil fuels, thus reducing emissions. But who is "responsible" for this reduction, and on what grounds?

- Government (for sponsoring the initiative)?

- The refrigerator manufacturer (for building the refrigerator)?

- The refrigerator dealer (for choosing to buy and carry the efficient model in preference to some other model)?

- The electric utility (for offering the rebate)?

- The customer (for choosing to buy the refrigerator)?

- The customer (for purchasing less electricity)?

- The electric utility (for burning less fuel)?

- Some other electric utility (for burning less fuel, as a consequence of selling less electricity to the customer's utility)?

There is no perfectly satisfactory answer to this question. All of the participants have some influence on the eventual outcome. Further, "responsibility" can have multiple meanings. Will a firm be made legally responsible for the emissions in some hypothesized future regulatory environment? Or, alternatively, who gets "recognition" for taking an action that reduces emissions?

In addition, different observers could choose a particular responsible party for different reasons, which means that they might agree on this example and disagree on some other example. Some might view the payment of the rebate as the "act" that makes the utility the "responsible" party. Others might view the utility as the responsible party because it was the utility whose emissions actually declined.

The guidelines, in accordance with legislative provisions and the objective of broad participation, do not assign the "right" to report emissions or reductions. Thus, in the Voluntary Reporting Program, all of the participants in the hypothetical transaction described above would be permitted to report on the reduction achieved as a consequence of their actions. Thus, everyone involved can justifiably report on an action to reduce emissions, since ownership in this case is not exclusive.

This decision created, not surprisingly, second-order problems for the design of the reporting system. The two largest problems were: 
- Multiple entities could report on the same project, a contingency dubbed "multiple reporting."

- Since reporters' definitions of "their" emissions and reductions are, in principle, restricted only by the reporters' (possibly inclusive) notions of the nature of causation, it could be very difficult to determine the actual origin of the claimed emissions and reductions.

The design of the Voluntary Reporting Program took several steps to identify instances of multiple reporting and to clarify reporters' definitions of emissions. To clarify instances of multiple reporting, project-level reporters are asked whether other entities might be reporting on the same activity and, if so, who. Reporters are also asked about joint-venture partners (if any) for projects, which helps to identify a particular class of multiple reporting with precision.

In order to clarify the reporters' definitions of "ownership" of emissions, the guidelines define (and the forms implement) the concept of "direct" and "indirect" emissions. A "direct" emission is an emission from a source owned and controlled by the reporter. If you drive a car, the emissions from the tailpipe of your car are direct emissions (for you). "Indirect" emissions are emissions that the reporter in some sense "caused" to occur, although the reporter did not own or control the facility producing the emission.

Direct emissions correspond to the most restrictive, and most intuitive, sense of "ownership" of emissions. Indirect emissions account for less restrictive definitions of ownership or responsibility. The Voluntary Reporting Program requires reporters to distinguish between "direct" and "indirect" emissions, and this distinction has proved very useful in understanding reporters' definitions of "ownership."

In practice, with a few exceptions, reporters tended to have very straightforward and intuitive definitions of "their" emissions and "their" reductions. However, these straightforward and intuitive definitions were not always consistent across reporters. In general, nearly everyone tended to accept the notion that direct emissions and reductions belong to the owner of the source producing the emissions. Thus, if a reporter owns and operates a fossil fuel power plant, usually the reporter views himself as responsible for the emissions of the plant.

In the case of sales of electricity, views were much more diverse. Electricity consumers, such as households and manufacturing firms, tended to view themselves as responsible for indirect emissions arising from their use of electricity. On the other hand, electric utilities also tended to view themselves as responsible for their customers' use of electricity. ${ }^{44}$

Reporters accounted for wholesale electricity transactions in various ways:

- Distribution-only electric utilities tended to behave like end-use consumers, and to view themselves as responsible for the electricity consumption of their customers and, hence, for the indirect emissions of their suppliers.

- Electric utilities that both bought and sold electricity had diverse views: some utilities assumed responsibility only for their direct emissions (i.e., sales to wholesale and retail customers, but no responsibility for electricity purchases).

- Other utilities added direct emissions to wholesale purchases but did not deduct wholesale sales. (This is the approach recommended in the instructions.)

- Still others summed their purchases and wholesale sales of electricity to calculate "net" indirect emissions as an addition to direct emissions.

Each approach produces a different figure for the total emissions of the reporter, and there is no theoretical basis for defining one particular approach as "correct." Each approach has conceptual and practical merits and drawbacks, depending on the intended purpose of the calculation and the circumstances of the particular reporter.

In general, the treatment of wholesale power transactions is important only for those electric utilities that (a) have large wholesale power sales relative to generation and retail sales (if the number is tiny, it matters little what accounting convention one follows); (b) large changes in the level of wholesale power sales (if the number does not change much, it will not affect reductions); (c) are using a "basic" reference case (if the reduction is defined as the outcome of a set of actions, the level of wholesale power transactions will not affect the magnitude of the reduction).

The importance of wholesale power transactions is likely to grow in the near future, however, since it is probable that pending changes in transmission access regulations will greatly increase the amount of electric power that is traded among utilities in the United States. In the absence of a common definition of responsibility for wholesale transactions, it will be

\footnotetext{
${ }^{44}$ Curiously, gas utilities did not view themselves as responsible for their customers' use of natural gas, even when the same utility sold both electricity and gas to the same customer.
} 
increasingly difficult to compare reports from different utilities without a careful study of the underlying assumptions.

As a hypothetical example, it is possible to consider the case of Detroit Edison, described in Chapter 2. Detroit Edison has large wholesale power sales that declined rapidly in the early 1990s, and is using a basic reference case. In this instance, Detroit Edison's emissions would have been roughly stable (rather than declining) from 1990 through 1993 and risen sharply in 1994. This result occurs because the decline in Detroit Edison's power sales offset the decline in its wholesale purchases, producing little change in net emissions.

\section{Reporting Fuel Cycle Effects}

"Primary effects" and "secondary effects" are terms that are defined in the guidelines. The guidelines were concerned with the notion that reporters could claim reductions from actions that actually would produce much larger emissions somewhere else. This notion is linked to the concept of fuel cycle effects. As an example, a reporter claims to have reduced emissions by replacing his gasoline-powered automobile with an electric automobile. The primary effect is the direct reduction in emissions from the reduction in burning gasoline. Most reporters would consider the increased electricity consumption due to the electric automobile to be a primary effect as well, though an indirect emission.

There are also a host of other (secondary) effects that one might wish to consider. Mining additional coal and producing additional natural gas causes additional emissions of methane, another secondary effect. Reducing gasoline consumption also reduces emissions from oil refining and methane emissions from crude oil and gasoline transportation and storage, a positive secondary effect.

Primary and secondary effects are loosely related to direct and indirect emissions. Direct emissions reductions are generally the primary effect. Indirect emissions reductions may be a primary or a secondary effect. However, the secondary effects almost always cause indirect emissions, even though not all indirect emissions are secondary effects.

Despite the amount of space given to primary and secondary effects in the guidelines, reporters almost universally ignored secondary effects (whether positive or negative) in their reporting. When queried about this point, reporters tended to argue that they had no basis for estimating secondary effects, which would require "certifying the accuracy" of an estimate of emissions from other industries remote in space and time from the reporter's knowledge and concern.

\section{The Nature of the Reference Case}

The emphasis of the Voluntary Reporting Program is on reporting reductions in emissions. However, the development of the guidelines raised the question of: reductions compared to what? The guidelines developed the notion that a "reduction" in emissions is defined by comparison with an alternative situation. This alternative situation was called a "reference case." The guidelines defined two ways in which a reference case could be defined: "basic" and "modified."

A basic reference case is the most straightforward. A basic reference case is the reporter's level of emissions at some period in the recent past: for example, the reporter's emissions in the year 1990. This definition is closest to the definitions implicit in the Framework Convention and those used in the Clean Air Act emissions trading scheme. If the reporter's emissions today are less than they were in 1990, then the size of the reporter's reduction is equal to the difference between current emissions and 1990 emissions.

Basic reference cases are most meaningful in the context of entity-wide emissions. When applied to specific projects, a basic reference case can often become ambiguous or meaningless. For example, suppose an electric utility offers a program to induce homebuilders to add more energy-efficient appliances to newly constructed houses. The new appliances will consume less energy in the future than some alternative device, but there are no baseline historic emissions. Any new project that is not an exact, one-for-one replacement for an old project faces a similar problem. Calculating a basic reference case for reforestation projects presents a similar problem. If the project is to plant trees, what was the level of secuestration before the trees were planted? In this instance, it is useful to recall that one of the purposes of the voluntary reporting program is to recognize and encourage actions that tend to reduce greenhouse gas emissions, whether they are new or existing sources.

In the Voluntary Reporting Program, therefore, a second method of calculating reductions is provided: the "modified reference case." A modified reference case is, in effect, a hypothetical case: the notion is that a reporter's emissions would have been higher, if he had not taken certain actions. Thus, in the example above, a modified reference case for the reforestation project would be the amount of carbon sequestered on 
a given parcel of land without the reforestation project, and the reduction (or sequestration) would be the difference between the amount of carbon actually sequestered and the amount that would have been sequestered without trees being planted. In the case of the electric utility, the "modified reference case" would be the putative emissions of the new houses with the appliances that homebuilders would have chosen without the intervention of the electric utility, and the reduction would be the difference between emissions with the energy-efficient appliances and emissions with "typical" appliances.

Modified reference cases always have a degree of uncertainty about them, since it is never possible to be absolutely certain about what would have happened in the absence of a particular action. However, by providing modified reference cases, the guidelines permitted the reporting of an extensive range of important and interesting projects. In practice, most project reports used various forms of a modified reference case. About two-thirds of entity-wide reporters also used a modified reference case, indicating that while emissions increased, they did not increase as much as they would have increased in the absence of actions by the reporter.

\section{Mergers and Acquisitions}

The definition of reference cases for measuring reductions presupposes that the definition of the entity itself remains stable over time. This is not always the case. Firms can merge, buy and sell assets, expand, shrink, or even go out of business altogether.

When this occurs, the basis for comparing past emissions with present emissions becomes more complex. During this year's reporting cycle, there were two cases that raised measurement issues:

- In 1990, Pacificorp purchased certain coal-fired power plants from Arizona Public Service Corporation. Pacificorp initially considered incorporating the emissions of these plants prior to 1990 in order to provide a profile of emissions from a consistent set of facilities. Arizona Public Service wished to include the pre-1990 emissions of these plants in their emissions profile as well. Ultimately, Pacificorp decided not to report pre-1990 emissions from the plant.

- In 1995, two reporters, Baltimore Gas \& Electric and Potomac Electric Power Company, agreed to merge. For this year, the two firms provided separate reports. In the future, however, the merged firm will probably file a single report. Merging the historical emissions of the two firms produces a non- historical reference case, though it is a logical basis for comparing with current and future emissions.

In general there are three approaches to an entity that is changing shape over time. One can either accept that a changing entity will produce changing emissions, and report the results, or one can restate historical emissions "as if" the new entity had always existed. Finally, one can restate current emissions "as if" the older form of the entity existed today.

In general, each of these approaches will have its merits in particular situations. In many cases, however, the problem will be best dealt with by properly accounting for changes in indirect emissions. For example, if a utility signs a power purchase agreement with an independent power producer (IPP), in principle it is outsourcing its power generation, and a reduction in direct emissions (from the utility's own capacity) is offset by an increase in indirect emissions (from the IPP).

\section{Domestic and Foreign Actions}

Reporters are permitted to file reports on actions both within the United States and abroad. However, reporters are required to distinguish between domestic and foreign emissions and reductions and report them separately. The rationale for this distinction is that, on the one hand, the President's commitment under the Framework Convention is to reduce domestic emissions. Therefore, only domestic emissions "count" in achieving the President's commitment. On the other hand, it has long been an objective of U.S. climate change policy to promote "joint implementation," wherein one country participates in emissions reduction projects in another country. Further, since greenhouse gas emissions have equal consequences no matter where the source of the emissions is located, foreign reductions are just as valuable as domestic reductions in ameliorating climate change. Therefore, both kinds of report are permitted, while the distinction between domestic and foreign reports is preserved. In practice, only a relatively small number of reports were received relating to projects or activities abroad, largely forestry projects.

\section{Confidentiality}

Section 1605(b)(3) requires the Energy Information Administration to offer protection from publication and Freedom of Information Act requests to reporters who are submitting trade secret and commercial or financial information. In practice, for most firms wishing to participate in a public, voluntary program, one of whose 
benefits is public recognition of their actions, confidentiality is unnecessary. Firms worried about proprietary data can refrain from reporting, or design their reporting definitions to protect proprietary data. In 1995, only three firms requested confidentiality and generally only for a limited amount of information.

\section{Emissions Trading}

One of the most striking uses of a voluntary report occurred in November 1994, when Niagara Mohawk Power Corporation and the Arizona Public Service Company engineered the first-ever trade of carbon dioxide emissions reductions. Niagara Mohawk, which reported 1.6 million metric tons of carbon emissions reductions to the EIA under the Voluntary Reporting Program, traded the "ownership" and any future benefits that might accrue from this emissions reduction to the Arizona Public Service Company in exchange for 25,000 sulfur dioxide allowances (obtained by Arizona Public Service under the Clean Air Act Amendments).

Niagara Mohawk indicated that it intended to donate the sulfur dioxide allowances to a nonprofit environmental organization, which then canceled the sulfur allowances. Niagara Mohawk also indicated that it intended to use the tax benefits associated with the donation to fund additional greenhouse gas emissions reduction projects.

\section{Data Validation and Accuracy}

Section 1605(b) of the Energy Policy Act requires the Secretary of Energy to issue guidelines that "establish procedures for the accurate voluntary reporting of greenhouse gases." During the development of the Voluntary Reporting Program, there was considerable discussion of the related topics of "data validation" and "data accuracy." Some observers, who were concerned about the accuracy of emissions reporting, recommended "third-party validation," meaning, in essence, reviews or audits of reporting by disinterested third parties. The law also states: "Persons reporting under this subsection shall certify the accuracy of the information reported." That sentence has been interpreted to mean that it is the reporter who is responsible for the accuracy and correctness of the emissions and reductions claimed in the Voluntary Reporting Program.

The EIA devoted considerable effort to the review of incoming reports. Each report was assigned to an EIA reviewer, who reviewed the reported information for internal consistency, accuracy of calculation, and comparability with other sources of information. The reviewer then prepared a list of issues for discussion with the reporter, who was asked about possible problem areas identified in the review. In some cases, reporters subsequently chose to revise their reports. All of the information described in this document is the product of that review process.

This work has given the EIA useful insights into the potential and limitations of data validation and accuracy. First, nothing in the review process gave the slightest credence to the notion that reporters deliberately prepared and submitted inaccurate voluntary reports. Reporters found the task of developing emissions and reductions estimates sufficiently daunting in itself. The notion of deliberately inaccurate reporting has tended to divert attention from the genuine problems faced by reporters in attempting to prepare accurate reports. Some of those real problems include:

- Lack of generally accepted "accounting standards" for emissions. This left each reporter to make judgments about the limits of the reporting entity and the ownership of emissions. Most reports were clear about the judgments that had been made, but it still can be difficult to aggregate and compare reports.

- Imprecision in estimation methods. Emissions of greenhouse gases generally are estimated on the basis of operating data, particularly, consumption of fossil fuels. Estimates of direct emissions from the combustion of fossil fuels should be reasonably accurate; however, there are significant uncertainties inherent in the estimation of indirect emissions generally, as well as in the estimation of emissions (direct or indirect) of other gases (particularly, methane and nitrous oxide). Many reporters chose not to report indirect emissions or emissions of other gases because of those uncertainties.

- Limited expertise in emissions estimation. Organizations rarely collect information on greenhouse gas emissions, and they have no reason to develop corporate expertise in estimating emissions. Reporters must start from scratch in collecting underlying operating data and developing expertise in estimating emissions on the basis of operating data.

- Limited availability of data within the organization. A comprehensive emissions and reductions report might cover direct combustion of fossil fuels, electricity purchases, use of halogenated substances as refrigerants and solvents, consumption of transportation fuels (gasoline and diesel), and any process emissions peculiar to the reporter. Collecting such information within an organization can present significant challenges, particularly for manufacturing companies, where energy is a relatively small portion of total operating costs. Companies may not 
collect fuel, electricity, or refrigerant consumption data at all, and many companies may record financial (but not quantitative) data in their accounting systems. Alternatively, the information may be collected only at the local (plant) level and never forwarded to corporate headquarters. In such cases, the person preparing the report must obtain information from a host of individual plant managers. Personnel in separately managed subsidiaries may be unable or unwilling to provide information. While current data may be available, historical data may be destroyed, archived, or otherwise practically unrecoverable.

These considerations have shaped the reports submitted to the Voluntary Reporting Program. Reporters have tended to calculate emissions where data are available, to make the calculations they can make, and to form reasonable judgments about what information they should meaningfully include.

Perhaps one of the principal benefits of the Voluntary Reporting Program to reporters is its educational value. Climate change may become a matter of increasing public concern in the future, and organizations may consequently wish to determine the extent of their greenhouse gas liabilities. To do this, they would need to go through a process essentially identical to preparing a report under the Voluntary Reporting Program. By educating reporters on the sources of greenhouse gas emissions within their organizations, the Voluntary Reporting Program helps to create the expertise needed to identify possible new low-cost methods for reducing emissions. 



\section{Appendix A \\ Reporters}

\begin{tabular}{|c|c|c|c|c|}
\hline Program Participant & Form & $\begin{array}{c}\text { Number of } \\
\text { Projects Reported } \\
\text { (Schedule II) }\end{array}$ & $\begin{array}{c}\text { Entity-Wide Report } \\
\text { (Schedule III) }\end{array}$ & $\begin{array}{c}\text { Future Commitments } \\
\text { (Schedule IV) }\end{array}$ \\
\hline Alcan Ingot, Sebree Aluminum Plant & Long & 1 & $N$ & $\mathbf{N}$ \\
\hline Allegheny Power Service Corporation & Long & 23 & $Y$ & $\mathbf{Y}$ \\
\hline American Electric Power, Inc. & Long & 31 & $\mathbf{N}$ & $\mathbf{N}$ \\
\hline Änoka Municipal Ütility & Short & 4 & $n$ & $N$ \\
\hline Arizona Electric Power Cooperative & Short & 3 & $N$ & $\mathbf{N}$ \\
\hline Arizona Public Service Company & Long & 0 & $Y$ & $Y$ \\
\hline Arthur Rypinski \& Jacquelyn Porth & Long & 5 & $\mathrm{Y}$ & $N$ \\
\hline Atlantic Energy, Inc. (AEI) & Long & 5 & $\mathbf{N}$ & $\mathbf{Y}$ \\
\hline Baltimore Gas \& Electric Company & Long & 9 & $Y$ & $Y$ \\
\hline Berkeley Electric Cooperative & Short & 2 & "N" & $N$ \\
\hline Bountiful City Light \& Power & Short & 2 & $\mathbf{N}$ & $\mathbf{N}$ \\
\hline Brooklyn Union & Short & 5 & $N$ & $\mathbf{N}$ \\
\hline Buckeye Power, Inc. & Long & 3 & $N$ & $N$ \\
\hline Carolina Power \& Light Company & Long & 1 & $\mathbf{N}$ & $N$ \\
\hline Carter H. Lewis, III & Short & 2 & $N$ & $N$ \\
\hline Codar Falis Ütilities & "Long & 14 & $\mathrm{Y}$ & $Y$ \\
\hline Centerior Energy Corporation & Long & 3 & $Y$ & $Y$ \\
\hline Central Hudson Gas \& Electric Corporation & Long & 6 & $Y$ & $Y$ \\
\hline Central iilinois Light Company & Long & 4 & 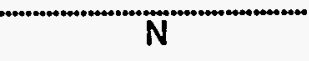 & $\mathrm{Y}$ \\
\hline Central Illinois Public Service Company & Long & 0 & $\mathbf{Y}$ & $\mathbf{N}$ \\
\hline Central Louisiana Electric Company, Inc. & Long & 0 & $N$ & $Y$ \\
\hline Cinergy Corporation & Long & 23 & $\mathrm{Y}$ & $n$ \\
\hline City of Austin Electric Utility & Long & 4 & $Y$ & Y \\
\hline City of Edmond (Oklahoma) Electricity Dept. & Short & 4 & $\mathbf{N}$ & $\mathbf{N}$ \\
\hline City of Sherrill (New York) Power \& Light & Short & 1 & N & $\mathbf{N}$ \\
\hline City of Wayne, Nebraska & Short & 4 & $\mathbf{N}$ & $\mathbf{N}$ \\
\hline City of Palo Alto (California) Utilities Dept. & Short & 6 & $N$ & $N$ \\
\hline City Utilities of Springfield, Missouri & Long & 3 & $N$ & $N$ \\
\hline Commonwealth Edison Company & Long & 4 & $N$ & $Y$ \\
\hline Cooperative Power Association & Long & $13^{\circ}$ & $\mathbf{N}$ & $Y$ \\
\hline Delmarva Power & Long & 7 & $\mathbf{N}$ & $N$ \\
\hline Delta Electric Power Association & Short & 2 & $\mathbf{N}$ & $N$ \\
\hline Duke Power Company & Long & 6 & $Y$ & $\mathbf{N}$ \\
\hline East River Electric Power Cooperative & Short & 6 & $\mathbf{N}$ & $N$ \\
\hline Entergy Services, Inc. & Long & 5 & $Y$ & $\mathbf{N}$ \\
\hline Flint EMC & Short & 3 & $\mathbf{N}$ & $\mathbf{N}$ \\
\hline Florida Power \& Light Company & Long & 0 & $\mathrm{Y}$ & $\mathbf{Y}$ \\
\hline General Motors Corporation & Long & 2 & $\mathbf{Y}$ & $\mathbf{N}$ \\
\hline General Public Utilities Corporation & Long & 29 & $N$ & $\mathbf{N}$ \\
\hline "Golden Valley Ëlectric Association, Inc. & Short & 4 & $N$ & $N$ \\
\hline Hopkinsville Electric System & Short & 1 & $N$ & $\mathbf{N}$ \\
\hline Houston Lighting \& Power Company & Long & 5 & $Y$ & $Y$ \\
\hline
\end{tabular}




\begin{tabular}{|c|c|c|c|c|}
\hline Program Participant & Form & $\begin{array}{c}\text { Number of } \\
\text { Projects Reported } \\
\text { (Schedule II) }\end{array}$ & $\begin{array}{l}\text { Entity-Wide Report } \\
\text { (Schedule III) }\end{array}$ & $\begin{array}{c}\text { Future Commitments } \\
\text { (Schedule IV) }\end{array}$ \\
\hline IBM & Long & 1 & $\mathbf{N}$ & $\mathbf{N}$ \\
\hline Illinois Power Company & Long & 16 & Y & $\mathrm{Y}$ \\
\hline Johnson \& Johnson & Long & 4 & $\mathbf{N}$ & $N$ \\
\hline Kansas City Power \& Light Company & 'Long & 4 & $Y$ & $\mathbf{Y}$ \\
\hline Long Island Lighting Company & Long & 0 & Y & $N$ \\
\hline Los Angeles Dept. of Water and Power & Long & 0 & $Y$ & $N$ \\
\hline Lowar Colorado River Authority & "Long & 2 & Y" & $\mathrm{Y}$ \\
\hline McMinnville Electric System & Short & 1 & $\mathbf{N}$ & $N$ \\
\hline Minnesota Power & Long & 7 & $N$ & $Y$ \\
\hline Missouri Basin Municipal Power Agency & Short & 1 & 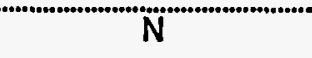 & $N$ \\
\hline Montana Power Company & Long & 5 & $\mathrm{~N}$ & $\mathrm{Y}$ \\
\hline Moorhead Public Service & Short & 2 & $\mathrm{~N}$ & $N$ \\
\hline Mora Municipal Utilities & Short" & 3 & $n$ & N" \\
\hline Municipal Electric Authority of Georgia & Long & 1 & $\mathrm{Y}$ & $\mathrm{Y}$ \\
\hline N.C. Electric Membership Corporation & Short & 1 & $N$ & $N$ \\
\hline Nashville Electric Service & Short" & 2 & N & N" \\
\hline Nebraska Public Power District & Short & 5 & $\mathbf{N}$ & N \\
\hline New England Electric System (NEES) Cos. & Long & 9 & $Y$ & Y \\
\hline New York Power Authority & Long & 0 & $\mathrm{Y}$ & 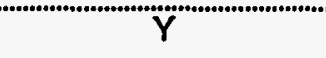 \\
\hline Niagara Mohawk Power Corporation & Long & 11 & 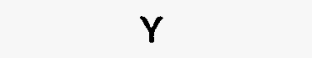 & Y \\
\hline NIPSCO Industries & Long & 17 & $Y$ & $Y$ \\
\hline Noranda Aluminum, Inc. & Long & 1 & $\mathrm{~N}$ & "Y" \\
\hline Northeast Utilities & Long & 6 & Y. & Y \\
\hline Northern States Power Company & Long & 6 & $N$ & Y \\
\hline Northwest Fuel Development, Inc. & Long & 1 & $N$ & $N$ \\
\hline Ohio Edison Company & Long & 8 & $Y$ & $Y$ \\
\hline Omaha Public Power District & Short & 9 & $\mathrm{~N}$ & $N$ \\
\hline Oregon State University (State of Oregon) & Long & 1 & $N$ & $N$ \\
\hline Osage Municipal Utilities & Long & 11 & $\mathbf{N}$ & $Y$ \\
\hline Pacific Gas and Electric Company & Short & 6 & $\mathbf{N}$ & $N$ \\
\hline Pacificorp & Long & 23 & $Y$ & $Y$ \\
\hline Peabody Holding Company, Inc. & Long & 1 & Y & $\mathbf{N}$ \\
\hline Pennsylvania Power \& Light Co. (PP\&L) & Long & 9 & Y & $Y$ \\
\hline Portland General Electric Company & Long & 9 & $\mathrm{Y}^{\prime \prime}$ & N" \\
\hline Potomac Electric Power Company & Long & 2 & $\mathrm{Y}$ & $\mathbf{N}$ \\
\hline Public Service Electric and Gas Company & Long & 0 & $Y$ & Y \\
\hline Public Utility Dist. No. 1 of Snohomish County. & Long & 7 & $n "$ & N \\
\hline Puget Sound Power \& Light Company & Long & 1 & $\mathbf{N}$ & N \\
\hline Salt River Project & Short & 3 & $N$ & $N$ \\
\hline Santeo Cooper & Long & 4 & N" & $\mathrm{Y}$ \\
\hline Seattle City Light & Long & 12 & $N$ & $\mathbf{N}$ \\
\hline Seminole Electric Cooperative, Inc. & Short & 4 & $N$ & $N$ \\
\hline Shrewsbury Electric Light Plant & Short & 2 & N" & "N" \\
\hline Sierra Pacific Power Company & Long & 4 & $Y$ & $\mathrm{Y}$ \\
\hline Southern California Edison Company & Long & 5 & $N$ & $Y$ \\
\hline
\end{tabular}




\begin{tabular}{|c|c|c|c|c|}
\hline Program Participant & Form & $\begin{array}{c}\text { Number of } \\
\text { Projects Reported } \\
\text { (Schedule II) }\end{array}$ & $\begin{array}{c}\text { Entity-Wide Report } \\
\text { (Schedule III) }\end{array}$ & \begin{tabular}{|c} 
Future Commitments \\
(Schedule IV)
\end{tabular} \\
\hline Stouben Rural Electric Cooperative & Short & 2 & $N$ & $N$ \\
\hline Tacoma Public Utilities & Short & 3 & $\mathbf{N}$ & $\mathbf{N}$ \\
\hline Taunton Municipal Lighting Plant & Short & 4 & $N$ & $N$ \\
\hline Tonnesseo Vailley Authority & Long & 15 & $\mathrm{Y}$ & $\mathrm{Y}$ \\
\hline Texas Utilities Electric Company & Long & 7 & $\mathbf{N}$ & $\mathrm{Y}$ \\
\hline The Detroit Edison Company & Long & 6 & $Y$ & $\mathbf{N}$ \\
\hline The Southern Company & Long & 9 & $Y$ & $N$ \\
\hline Trees for the Future & Long & 7 & $\mathbf{N}$ & N \\
\hline Union Electric Company & Long & 12 & $\mathbf{N}$ & $N$ \\
\hline Ünited Power Association & Long & 8 & "N" & $n$ \\
\hline Utah Municipal Power Agency & Short & 4 & $N$ & $N$ \\
\hline Utility Board of Key West, Florida & Short & 4 & $N$ & N \\
\hline Vermont Public Power Supply Authority & Long & 12 & $N$ & N \\
\hline Waverly (lowa) Light \& Power Company & Long & 9 & $Y$ & $Y$ \\
\hline Western Resources, Inc. & Long & 17 & $\mathbf{N}$ & $N$ \\
\hline Wisconsin Electric Power Company & "long & 8 & $\mathrm{~N}$ & Y' \\
\hline Wisconsin Power \& Light & Long & 9 & Y & $\mathrm{Y}$ \\
\hline Wisconsin Public Power, Inc. & Short & 13 & $N$ & $N$ \\
\hline Wisconsin Public Servico Corporation & "iong & 3 & $\mathrm{Y}$ & $Y$ \\
\hline Zahren Alternative Power Corporation & Short & 10 & N & $N$ \\
\hline Zeeland (Michigan) Board of Public Works & Short & 3 & $\mathrm{~N}$ & $N$ \\
\hline
\end{tabular}

Source: Energy Information Administration, Forms ElA-1605 and ElA-1605EZ, "Voluntary Reporting of Greenhouse Gases" (1995 reporting cycle). 



\section{Appendix B
List of Projects by Reporter}

\begin{tabular}{|c|c|c|c|}
\hline Reporter/Project & Form & U.S. or Foreign & Project Type \\
\hline Alcan Ingot, Sebree Aluminum Plant (Henderson, KY) & Long & & \\
\hline PFC Emissions Reductions & & U.S. & Halogenates \\
\hline Allegheny Power Service Corporation (Greensburg, PA) & Long & & \\
\hline Armstrong Boiler \#2 Renovation Project & & U.S. & Electric Power G \& T \\
\hline Auxiliary Fuel Switching & & U.S. & Electric Power G \& $T$ \\
\hline Wire Replacement on Transmission Lines & & U.S. & Electric Power G \& T \\
\hline Potomac Edison Company 138/500 kV System Split & & U.S. & Electric Power G \& T \\
\hline Boiler Controls Replacement & & U.S. & Electric Power G \& $T$ \\
\hline Boiler Controls Replacement & & U.S. & Electric Power G \& T \\
\hline Boiler Controls Replacement & & U.S. & Electric Power G \& T \\
\hline High Pressure/Intermediate Pressure Turbine Upgrade - Unit 1 & & U.S. & Electric Power G \& T \\
\hline High Pressure/Intermediate Pressure Turbine Upgrade - Unit 2 & & U.S. & Electric Power G \& T \\
\hline High Pressure Turbine Upgrade & & U.S. & Electric Power G \& $T$ \\
\hline Low Pressure Turbine Upgrade & & U.S. & Electric Power G \& $T$ \\
\hline Nox Compliance with Clean Air Act Amendments of 1990 & & U.S. & Electric Power G \& T \\
\hline Efficient Distribution Transformers & & U.S. & Electric Power G \& $T$ \\
\hline Application of Capacitors & & U.S. & Electric Power G \& T \\
\hline Economic Conductor Selection & & U.S. & Electric Power G \& T \\
\hline Replace Small Primary Conductors & & U.S. & Electric Power G \& T \\
\hline Conversion to Higher Voltage Distribution & & U.S. & Electric Power G \& T \\
\hline Small Hydroelectric Station Relicensing & & U.S. & Electric Power $\mathrm{G} \& \mathrm{~T}$ \\
\hline Demand-Side Management Programs & & U.S. & Energy End Use \\
\hline Green Lights Utility Ally Program & & U.S. & Energy End Use \\
\hline Heat Pipe Heat Exchanger & & U.S. & Energy End Use \\
\hline Adjustable Speed Drives for Plastic Injection Molding Machine & & U.S. & Energy End Use \\
\hline Canonsburg Plant Upgrade & & U.S. & Waste Methane \\
\hline American Electric Power, Inc. (Columbus, $\mathrm{OH}$ ) & Long & & \\
\hline Heat Rate Improvement Project & & U.S. & Electric Power $\mathrm{G} \& \mathrm{~T}^{\circ}$ \\
\hline Heat Rate Improvement Projects- Load Optimization & & U.S. & Electric Power G \& T \\
\hline Open-Loop Transmission Groundwire Resistive Loss Reduction & & U.S. & Electric Power G \& T \\
\hline Distribution System Equipment Improvements & & U.S. & Electric Power G \& T \\
\hline Transmission System Reinforcements & & U.S. & Electric Power G \& T \\
\hline Nuclear Plant Improved Utilization & & U.S. & Electric Power G \& T \\
\hline AEP Hydroelectric Facility Improvements & & U.S. & Electric Power G \& T \\
\hline Residential Demand Side Management Programs & & U.S. & Energy End Use \\
\hline Commercial/ndustrial Demand Side Management Programs & & U.S. & Energy End Use \\
\hline AEP-OPCo-1991P & & U.S. & Carbon Sequestration \\
\hline AEP-OPCo-1991H & & U.S. & Carbon Sequestration \\
\hline AEP-OPCo-1992H & & U.S. & Carbon Sequestration \\
\hline AEP-OPCo-1992P1 & & U.S. & Carbon Sequestration \\
\hline AEP-OPCo-1992P2 & & U.S. & Carbon Sequestration \\
\hline AEP-OPCo-1994P & & U.S. & Carbon Sequestration \\
\hline AEP-OPCo-1994H & & U.S. & Carbon Sequestration \\
\hline AEP-OPCo-1993P1 & & U.S. & Carbon Sequestration \\
\hline AEP-OPCo-1993H1 & & U.S. & Carbon Sequestration \\
\hline AEP-OPCo-1993P2 & & U.S. & Carbon Sequestration \\
\hline AEP-OPCo-1993P3 & & U.S. & Carbon Sequestration \\
\hline AEP-APCo-1993 & & U.S. & Carbon Sequestration \\
\hline AEP-APCo-1994 & & U.S. & Carbon Sequestration \\
\hline AEP-OPCo-1991FM & & U.S. & Carbon Sequestration \\
\hline
\end{tabular}




\begin{tabular}{|c|c|c|c|}
\hline Reporter/Project & Form & U.S. or Foreign & Project Type \\
\hline AEP-OPCo-1992FM & & U.S. & Carbon Sequestratio \\
\hline AEP-OPCo-1993FM & & U.S. & Carbon Sequestratio \\
\hline AEP-OPCo-1994FM & & U.S. & Carbon Sequestratio \\
\hline AEP-IMPCo-1994FM & & U.S. & Carbon Sequestratio \\
\hline AEP-IMPCo-1993FM & & U.S. & Carbon Sequestratio \\
\hline AEP-APCo-1993FM & & U.S. & Carbon Sequestratio \\
\hline AEP-APCo-1994FM & & U.S. & Carbon Sequestratio \\
\hline Fly Ash Utilization Program & & U.S. & Other \\
\hline Anoka (MN) Municipal Utility & Short & & \\
\hline Distrib. System Improvements & & U.S. & Electric Power G \& \\
\hline Demand Mgmt. Lighting Replace. & & U.S. & Energy End Use \\
\hline Central AV Replacement & & U.S. & Energy End Use \\
\hline Urban Forestry (Sequestration Only) & & U.S. & Energy End Use \\
\hline Arizona Electric Power Coop. (Benson, AZ) & Short & & \\
\hline Fly Ash Sales & & U.S. & Electric Power G \\
\hline Lighting/Sign Replacement & & U..S. & Energy End Use \\
\hline Utility Photovoltaic Group & & Ū.S. & Carbon Sequestratio \\
\hline Arthur Rypinski \& Jacquelyn Porth (Rockville, MD) & Long & & \\
\hline Compact Fluorescent Lightbulbs & & U.S. & Energy End Use \\
\hline Super Efficient Refrigerator & & U.S. & Energy End Use \\
\hline High Efficiency Water Heater & & U.S. & Energy End Use \\
\hline High Efficiency Central Air Conditioning System & & U.S. & Energy End Use \\
\hline Mass Transit Commuting & & U.S. & Transportation \\
\hline Atlantic Energy, Inc. (AEI) (Egg Harbor, NJ) & Long & & \\
\hline Peach Bottom Nuclear Units \#2 \& 3 Uprate Program & & U.S. & Electric Power G \\
\hline AGI - Pedricktown Cogeneration Limited Partnership & & U.S. & Cogeneration \\
\hline Binghamton Cogeneration Limited Partnership & & U.S. & Cogeneration \\
\hline AGI - Vineland Cogeneration Facility & & U.S. & Cogeneration \\
\hline Atlantic Electric DSM Resource Program & & U.S. & Energy End Use \\
\hline Baltimore Gas \& Electric Co. (Baltimore, MD) & Long & & \\
\hline Brandon Shores Heat Rate Improvement & & U.S. & Electric Power G \\
\hline Crane Heat Rate Improvement & & U.S. & Electric Power G \\
\hline H.A. Wagner Heat Rate Improvement & & U.S. & Electric Power G \& \\
\hline Hydroelectric Generation Improvements & & U.S. & Electric Power G \& \\
\hline Transmission / Distribution Improvements & & U.S. & Electric Power G \& \\
\hline Demand Side Management Programs & & U.S. & Energy End Use \\
\hline Gas Systems O \& M & & U.S. & Oil \& Gas Methane \\
\hline Refrigerant Recycling & & U.S. & Halogenates \\
\hline Solid Waste Recycling & & U.S. & Other \\
\hline Berkeley Electric Cooperative (Moncks Corner, SC) & Short & & \\
\hline Load Control Water Heater Repl. & & U.S. & Energy End Use \\
\hline DSM Mkt Good Cents Effic. Homes & & U.S. & Energy End Use \\
\hline Bountiful City (UT) Light \& Power & Short & & \\
\hline Lighting Repl. Street Lighting. & & U.S. & Energy End Use \\
\hline Lighting Repl. Residential CFL & & U.S. & Energy End Use \\
\hline Brooklyn Union Gas (Brooklyn, NY) & Short & & \\
\hline Rehab of Leaky Distribution Pipe & & U.S. & Oil \& Gas Methane \\
\hline Directed I\&M at Surface and Subsurface Facility & & U.S. & Oil \& Gas Methane \\
\hline Flaring When Retiring Gas Holders & & U.S. & Oil \& Gas Methane \\
\hline Installation of Primary Regulator at Gate Station & & U.S. & Oil \& Gas Methane \\
\hline Reduct. of Controller Venting at Gate Stations & & U.S. & Oil \& Gas Methane \\
\hline
\end{tabular}




\begin{tabular}{|c|c|c|c|}
\hline Reporter/Project & Form & U.S. or Foreign & Project Type \\
\hline Buckeye Power Inc. (Columbus, $\mathrm{OH}$ ) & Long & & \\
\hline Heat Rate Improvement Activities & & U.S. & Electric Power G \& $T$ \\
\hline Water Heater Replacement Program & & U.S. & Energy End Use \\
\hline Geothermal Heat Pump Project & & U.S. & Energy End Use \\
\hline Carolina Power \& Light Company (Raleigh, NC) & Long & U.S. & \\
\hline Nuclear Capacity Improvement & & & Electric Power G \& T \\
\hline Carter H. Lewis, III (Reston, VA) & Short & & \\
\hline Lighting Use Reduction & & U.S. & Energy End Use \\
\hline General Transportation Projects & & U.S. & Transportation \\
\hline Cedar Falls (IA) Utilities & Long & & \\
\hline Streeter Unit 6 Controls Upgrade (Project 1.1) & & U.S. & Electric Power G \& T \\
\hline High-Efficiency Transformers (Project 1.2) & & U.S. & Electric Power G \& T \\
\hline Co Owned Generation (Project 1.3) & & U.S. & Electric Power G \& T \\
\hline Co Owned Generation (Project 1.4) & & U.S. & Electric Power G \& T \\
\hline Council Bluffs \#3 ESP Hot-Side Conversion (Project 1.5) & & U.S. & Electric Power G \& T \\
\hline Neal \#4 ESP Hot-Side Conversion (Project 1.6) & & U.S. & Electric Power G \& T \\
\hline City Street Light Conversion (Project 3.1) & & U.S. & Energy End Use \\
\hline Home Energy Survey (Project 3.2) & & U.S. & Energy End Use \\
\hline Good Cents Home Program (New Homes) (Project 3.3) & & U.S. & Energy End Use \\
\hline Good Cents Improved Home (Project 3.4) & & U.S. & Energy End Use \\
\hline Security Lighting Service (Project 3.5) & & U.S. & Energy End Use \\
\hline Water Heater Jacket Rebate (Project 3.6) & & U.S. & Energy End Use \\
\hline Cooling Effects of Trees (Project 3.7) & & U.S. & Energy End Use \\
\hline Cedar Falls Trees (Project 8.1 ) & & U.S. & Carbon Sequestration \\
\hline Centerior Energy Corporation (Independence, $\mathrm{OH}$ ) & Long & & \\
\hline Demand Side Management & & U.S. & Energy End Use \\
\hline Various CFC Replacements & & U.S. & Halogenates \\
\hline Use of Ash in Cement Production & & U.S. & Other \\
\hline Central Hudson Gas \& Electric Corp. (Poughkeepsie, NY) & Long & & \\
\hline Roseton Gas Co-Firing & & U.S. & Electric Power G \& T \\
\hline Danskammer Heat Pipe Air Heater . & & U.S. & Electric Power G \& $T$ \\
\hline Roseton Unit 2 Main Step-Up Transformer Replacement & & U.S. & Electric Power G \& $T$ \\
\hline Danskammer Unit 4 Main Step-Up Transformer Replacement & & U.S. & Electric Power G \& T \\
\hline Demand-Side Management & & U.S. & Energy End Use \\
\hline Natural Gas Vehicles & & U.S. & Transportation \\
\hline Central Illinois Light Company (Peoria, IL) & Long & & \\
\hline EDE Unit \#3 Last Stage Bucket Heat Rate Improvement & & U.S. & Electric Power G \& T \\
\hline ClLCO Cogen One & & U.S. & Cogeneration \\
\hline Tazewell County Landfill Methane Outreach Program & & U.S. & Waste Methane \\
\hline In Concert With the Environment & & U.S. & Other \\
\hline Cinergy Corp. (Cincinnati, OH) & Long & & \\
\hline Gibson Performance Maximization Program & & U.S. & Electric Power G \& T \\
\hline Cayuga Heat Rate Improvements & & U.S. & Electric Power G \& T \\
\hline Wabash River Heat Rate Improvement & & U.S. & Electric Power G \& $T$ \\
\hline Residential Wrap-Up Program & & U.S. & Energy End Use \\
\hline Residential Energy Efficient Lighting Program & & U.S. & Energy End Use \\
\hline Residential Smart Saver \& Heat Pump Savings Programs & & U.S. & Energy End Use \\
\hline Residential Seal-Up \& Low-Income Efficiency Program & & U.S. & Energy End Use \\
\hline Commercial Audit/Incentive Plan & & U.S. & Energy End Use \\
\hline Commercial Direct Lighting & & U.S. & Energy End Use \\
\hline Industrial Efficiency Improvement \& Energy Awareness Program & & U.S. & Energy End Use \\
\hline Commercial/nndustrial Peak Reduction Program & & U.S. & Energy End Use \\
\hline Planergy & & U.S. & Energy End Use \\
\hline Green Lights Program & & U.S. & Energy End Use \\
\hline
\end{tabular}




\begin{tabular}{|c|c|c|c|}
\hline Reporter/Project & Form & U.S. or Foreign & Project Type \\
\hline Commercial/ndustrial Lighting Rebate Program & & U.S. & Energy End Use \\
\hline Thermal Energy (Cool Storage Program & & U.S. & Energy End Use \\
\hline Commercial/ndustrial High Efficiency Motors Plan & & U.S. & Energy End Use \\
\hline Commercial/nndustrial Adjustable Speed Drive Plan & & U.S. & Energy End Use \\
\hline Fleet Alternative Fuels & & U.S. & Transportation \\
\hline Danville, IN Electric Generation & & U.S. & Waste Methane \\
\hline Rumpke Landfill Gas Recovery & & U.S. & Waste Methane \\
\hline Facility Tree Planting Program & & U.S. & Carbon Sequestration \\
\hline Beneficial Use of Coal Fly Ash & & U.S. & Other \\
\hline Recycled Paper and Aluminum & & U.S. & Other \\
\hline City of Austin (TX) Electric Utility & Long & & \\
\hline Increasing Transmission Line Voltage & & U.S. & Electric Power G \& $T$ \\
\hline Photovoltaic Generation & & U.S. & Energy End Use \\
\hline Demand Side Management & & U.S. & Energy End Use \\
\hline Coal Combustion By-Products & & U.S. & Carbon Sequestration \\
\hline City of Edmond (OK) Electricity Department & Short & & \\
\hline High Efficiency Transformers & & U.S. & Electric Power G \& T \\
\hline High Efficiency Heat Pump Installation Program & & U.S. & Energy End Use \\
\hline Central Air Conditioner Replacement & & U.S. & Carbon Sequestration \\
\hline Tree/Shrub Planting & & U.S. & Other \\
\hline City of Sherrill (NY) Power \& Light & Short & & \\
\hline Tree Planting & & U.S. & Carbon Sequestration \\
\hline City of Wayne (NE) & Short & & \\
\hline High-Efficiency Transformers & & U.S. & Electric Power G \& T \\
\hline Other Energy Efficiency Projects (Load Control) & & U.S. & Energy End Use \\
\hline Tree Planting & & U.S. & Energy End Use \\
\hline Public Education on Energy Efficient Methods & & U.S. & Other \\
\hline City of Palo Alto (CA) Utilities Department & Short & & \\
\hline General Generation, Transmission \& Distribution & & U.S. & Electric Power G \& $T$ \\
\hline Refrigerator Replacement & & U.S. & Energy End Use \\
\hline Residential Lighting Replacement-"CFL Program" & & U.S. & Energy End Use \\
\hline City Lighting Replacement HPS Conversions & & U.S. & Energy End Use \\
\hline Employee Mass Transit Use & & U.S. & Transportation \\
\hline Carpooling & & U.S. & Transportation \\
\hline City Utilities of Springfield (MO) & Long & & \\
\hline Low Sulfur Fuel Switch - SWPS & & U.S. & Electric Power G \& T \\
\hline Heat Rate Improvements - SWPS & & U.S. & Electric Power G \& T \\
\hline Urban Forestry & & U.S. & Carbon Sequestration \\
\hline Commonwealth Edison Company (Chicago, IL) & Long & & \\
\hline Collins Station 123 Fuel Switch & & U.S. & Electric Power G \& T \\
\hline ComEd Energy Cooperative & & U.S. & Energy End Use \\
\hline Air Conditioning Tune-Up & & U.S. & Energy End Use \\
\hline High Efficiency Motor Rebate & & U.S. & Energy End Use \\
\hline Cooperative Power Association (Eden Prairie, MN) & Long & & \\
\hline L-o Buckets & & U.S. & Electric Power G \& T \\
\hline Ultrasonic \& Helium Leak Detection Improvements & & U.S. & Electric Power $\mathrm{G} \& \mathrm{~T}$ \\
\hline Cooling Tower Improvements & & U.S. & Electric Power G \& $T$ \\
\hline Energy Intelligent Business \& Farm Grants & & U.S. & Energy End Use \\
\hline Efficient Lighting & & U.S. & Energy End Use \\
\hline Water Heater Blankets & & U.S. & Energy End Use \\
\hline Low-Flow Showerheads & & U.S. & Energy End Use \\
\hline Setback Thermostats & & U.S. & Energy End Use \\
\hline Excess Water Heating Setting Reductions & & U.S. & Energy End Use \\
\hline Water Pipe Insulation & & U.S. & Energy End Use \\
\hline
\end{tabular}




\begin{tabular}{|c|c|c|c|}
\hline Reporter/Project & Form & U.S. or Foreign & Project Type \\
\hline Tree-Planting programs & & U.S. & Carbon Sequestration \\
\hline Coal Ash Programs & & U.S. & Other \\
\hline Recycling Projects \& Activities & & U.S. & Other \\
\hline Delmarva Power (Newark, DE) & Long & & \\
\hline T\&D Loss Reduction & & U.S. & Electric Power G \& T \\
\hline Hay Road Combined Cycle & & U.S. & Electric Power $G$ \& $T$ \\
\hline DP\&L Facility Energy Saving & & U.S. & Energy End Use \\
\hline Demand Side Management & & U.S. & Energy End Use \\
\hline CNG Vehicles & & U.S. & Transportation \\
\hline Urban Tree Planting & & U.S. & Carbon Sequestration \\
\hline Ash Reuse & & U.S. & Other \\
\hline Delta Electric Power Association (Greenwood, MS) & Short & & \\
\hline High Efficiency Transformers & & U.S. & Electric Power G \& $T$ \\
\hline Demand Side Management & & U.S. & Energy End Use \\
\hline Duke Power Company (Charlotte, NC) & Long & & \\
\hline Increased.Nuclear Generation & & U.S. & Electric Power G \& T \\
\hline Increased Nuclear Generation & & U.S. & Electric Power $G$ \& $T$ \\
\hline Increased Nuclear Generation & & U.S. & Electric Power $G \& T$ \\
\hline Reforestation & & U.S. & Carbon Sequestration \\
\hline Reforestation & & U.S. & Carbon Sequestration \\
\hline Recycling Fly Ash & & U.S. & Other \\
\hline East River Electric Power Cooperative (Madison, SD) & Short & & \\
\hline Transmission Efficiencies & & U.S. & Electric Power G \& T \\
\hline Renewable Energy Purchases - Wind Power & & U.S. & Electric Power $\mathrm{G} \& \mathrm{~T}$ \\
\hline DSM - Load Management & & U.S. & Energy End Use \\
\hline DSM - Efficient Equipment & & U.S. & Energy End Use \\
\hline Alternative Fuels - Ethanol Use & & U.S. & Transportation \\
\hline Industry Initiative Geothermal Heat Pumps & & U.S. & Other \\
\hline Entergy Services, Inc. (Beaumont, TX) & Long & & \\
\hline Ninemile Turbine Retrofit & & U.S. & Electric Power G \& T \\
\hline T\&D Efficiency & & U.S. & Electric Power $G \& T$ \\
\hline Vidalia Hydroelectric Station & & U.S. & Electric Power G \& T \\
\hline Lewis Creek Combustion Control & & U.S. & Electric Power G \& T \\
\hline Entergy SASI Lighting & & U.S. & Energy End Use \\
\hline Flint Electric Membership Corp (Warner-Robbins, GA) & Short & & \\
\hline Transmission and Distribution Upgrades & & U.S. & Electric Power G \& T \\
\hline DSM through Marketing (Heat Pumps, GoodCents) & & U.S. & Energy End Use \\
\hline DSM through Load Control & & U.S. & Energy End Use \\
\hline General Motors Corporation (Detroit, MI) & Long & & \\
\hline 1991-1994 General Motors Annual Energy Competition & & U.S. & Energy End Use \\
\hline 1993-1994 Michigan Demand Side Management Programs & & U.S. & Energy End Use \\
\hline General Public Utilities Corporation (Parsippany, NJ) & Long & & \\
\hline Yards Creek Pumped Storage Upgrade & & U.S. & Electric Power G \& T \\
\hline Seneca Pumped Storage Upgrade & & U.S. & Electric Power G \& T \\
\hline Sayreville Generating Station Retirements & & U.S. & Electric Power $\mathrm{G} \& \mathrm{~T}$ \\
\hline Front Street Generating Station Retirement & & U.S. & Electric Power G \& T \\
\hline Williamsburg Generating Station Retirement & & U.S. & Electric Power $G$ \& $T$ \\
\hline Transformer Loss Evaluation Program & & U.S. & Electric Power G \& T \\
\hline Shunt Capacitor Program & & U.S. & Electric Power G \& $T$ \\
\hline T \& D System Improvement & & U.S. & Electric Power $G$ \& $T$ \\
\hline TMI Capacity/Availability Improvement Program & & U.S. & Electric Power G \& T \\
\hline Oyster Creek Capacity/Availability Improvement Program & & U.S. & Electric Power G \& T \\
\hline Homer City Greenhouse Project & & U.S. & Cogeneration \\
\hline Met-Ed/Penelec DSM, Efficiency \& Electrotechnology Program & & U.S. & Energy End Use \\
\hline
\end{tabular}




\begin{tabular}{|c|c|c|c|}
\hline Reporter/Project & Form & U.S. or Foreign & Project Type \\
\hline JCP\&L DSM, Efficiency \& Electrotechnology Program & & U.S. & Energy End Use \\
\hline JCP\&L Green Lights Program & & U.S. & Energy End Use \\
\hline Met-Ed Lighting \& Building Energy Consumption Reduction Program & & U.S. & Energy End Use \\
\hline Building Energy Consumption Reduction Program & & U.S. & Energy End Use \\
\hline Genco Lighting \& Building Energy Consumption Reduction Program & & U.S. & Energy End Use \\
\hline Information Services - Green Computers & & U.S. & Energy End Use \\
\hline Video Conferencing & & U.S. & Transportation \\
\hline FR\&S Landfill NUG & & U.S. & Waste Methane \\
\hline Lebanon Methane NUG & & U.S. & Waste Methane \\
\hline Hamm's Landfill NUG & & U.S. & Waste Methane \\
\hline L\&D Landfill NUG & & U.S. & Waste Methane \\
\hline Corry & & U.S. & Waste Methane \\
\hline Valley Pork & & U.S. & Agriculture \\
\hline Mason Dixon Farms, Inc & & U.S. & Agriculture \\
\hline Transmission \& Distribution Facility Maintenance - JCP\&L & & U.S. & Halogenates \\
\hline JCP\&L Appliance Turn-In Service Program & & U.S. & Halogenates \\
\hline Recycling Program & & U.S. & Other \\
\hline Golden Valley Electric Association Inc. (Fairbanks, AK) & Shoit & & \\
\hline Use of Hydro Power & & U.S. & Electric Power G \& T \\
\hline Recycled Coal Ash & & U.S. & Electric Power G \& $T$ \\
\hline Energy Sense & & U.S. & Energy End Use \\
\hline Tree Giveaway Program & & U.S. & Carbon Sequestration \\
\hline Hopkinsville (KY) Electric System & Short & & \\
\hline Urban Forestry (Sequestration Only) & & U.S. & Carbon Sequestration \\
\hline Houston Lighting \& Power Company (Houston, TX) & Long & & \\
\hline GT Prime & & U.S. & Electric Power G \& T \\
\hline San Jacinto Steam Electric Generating Station & & U.S. & Cogeneration \\
\hline Demand Side Management & & U.S. & Energy End Use \\
\hline Rice Field Methane Reduction Study & & U.S. & Agriculture \\
\hline Coal Fly Ash Sales & & U.S. & Other \\
\hline IBM (Armonk, NY) & Long & & \\
\hline Reducs. as Result of Energy Cons. Activs. at IBM Locs. & & U.S. & Energy End Use \\
\hline Illinois Power Company (Decatur, IL) & Long & & \\
\hline Burn Waste Oil at Baldwin 3 & & U.S. & Electric Power G \& T \\
\hline Improve Clinton Power Station Availability & & U.S. & Electric Power G \& T \\
\hline Tire-Derived Fuel Cofiring at Baldwin & & U.S. & Electric Power G \& T \\
\hline Baldwin 3 Heat Rate Improvement & & U.S. & Electric Power G \& T \\
\hline Install Natural Gas Fired Aux. Boiler - Havana & & U.S. & Electric Power G \& T \\
\hline Convert Hennepin Aux. Boiler to Natural Gas & & U.S. & Electric Power G \& T \\
\hline Hennepin Gas Reburn Project & & U.S. & Electric Power G \& T \\
\hline New Boiler Controls at Hennepin & & U.S. & Electric Power G \& T \\
\hline Vermilion 1 Heat Rate Improvements & & U.S. & Electric Power G \& T \\
\hline Vermilion 2 Heat Rate Improvements & & U.S. & Electric Power G \& T \\
\hline Add Turbine Shell Heaters - Wood River 4 & & U.S. & Electric Power G \& T \\
\hline Fuel Switch to Natural Gas - Hennepin & & U.S. & Electric Power G \& T \\
\hline Fuel Switching to Natural Gas - Wood River 4 & & U.S. & Electric Power G \& T \\
\hline CNG Vehicle Conversions & & U.S. & Electric Power G \& T \\
\hline Baldwin 3 & & U.S. & Electric Power G \& T \\
\hline Fly Ash Sales & & U.S. & Other \\
\hline Johnson \& Johnson (New Brunswick, NJ) & Long & & \\
\hline Green Lights Upgrades & & U.S. & Energy End Use \\
\hline Installation of Energy Efficient Systems & & U.S. & Energy End Use \\
\hline Installation of Timer Controls and Shutdowns & & U.S. & Energy End Use \\
\hline Process Improvements & & U.S. & Energy End Use \\
\hline
\end{tabular}




\begin{tabular}{|c|c|c|c|}
\hline Reporter/Project & Form & U.S. or Foreign & Project Type \\
\hline Kansas City Power \& Light Company (Kansas City, MO) & Long & & \\
\hline Improve Heat Rate & & U.S. & Electric Power G \& T \\
\hline Nuclear Unit Uprate & & U.S. & Electric Power G \& $T$ \\
\hline EPA's Green Lights & & U.S. & Energy End Use \\
\hline Coal Fly Ash Recycling & & U.S. & Other \\
\hline Lower Colorado River Authority (Austin, TX) & Long & & \\
\hline Residential \& Commercial DSM Program & & U.S. & Energy End Use \\
\hline Coal Combustion By-Product Recycling & & U.S. & Other \\
\hline McMinnville (TN) Electric System & Short & & \\
\hline Urban Forestry (Sequestration Only) & & U.S. & Carbon Sequestration \\
\hline Minnesota Power (Duluth, MN) & Long & & \\
\hline Heat Rate Improvements, BEC & & U.S. & Electric Power G \& T \\
\hline Expanded Generation from Existing Hydro Electric Resources & & U.S. & Electric Power G \& T \\
\hline Demand Side Mgmt., Industrial Process Efficiency Improvement & & U.S. & Energy End Use \\
\hline Demand Side Mgmt., Conservation Improvements & & U.S. & Energy End Use \\
\hline Expanded Use of Renewable Biomass (Wood Waste) & & U.S. & Energy End Use \\
\hline Short Rotation Woody Crop Establishment & & U.S. & Carbon Sequestration \\
\hline Waste Paper Recycling Development & & U.S. & Other \\
\hline Missouri Basin Municipal Power Agency (Sioux Falls, SD) & Short & & \\
\hline Tree Planting & & U.S. & Carbon Sequestration \\
\hline Montana Power Company (Butte, MT) & Long & & \\
\hline Upgrades to Colstrip Coal Fired Units & & U.S. & Electric Power G \& T \\
\hline Hydro-Electric Plant Upgrades & & U.S. & Electric Power G \& T \\
\hline Demand Side Management Programs & & U.S. & Energy End Use \\
\hline Natural Gas Vehicles - Fleet Conversion & & U.S. & Transportation \\
\hline Gas Plant Catalytic Converters & & U.S. & Oil \& Gas Methane \\
\hline Moorhead Public Service (Moorhead, MN) & Short & & \\
\hline Insulation Improvement & & U.S. & Energy End Use \\
\hline Urban Forestry (Sequestration Only) & & U.S. & Carbon Sequestration \\
\hline Mora (MN) Municipal Utilities & Short & & \\
\hline Demand Side Management (Load Management) & & U.S. & Energy End Use \\
\hline Demand Side Management (Lighting Replacement) & & U.S. & Energy End Use \\
\hline Tree Planting & & U.S. & Agriculture \\
\hline Municipal Electric Authority of Georgia (Atlanta, GA) & Long & & \\
\hline Nuclear Generation Utilization & & U.S. & Electric Power G \& T \\
\hline North Carolina Electric Membership Corp. (Raleigh, NC) & Short & & \\
\hline Change in Purchased Power Generation & & U.S. & Electric Power $G \& T$ \\
\hline Nashville Electric Service (Nashville, TN) & Short & & \\
\hline Other Transmission \& Distribution Improvements & & U.S. & Electric Power G \& T \\
\hline Urban Forestry (Sequestration Only) & & U.S. & Carbon Sequestration \\
\hline Nebraska Public Power District (Columbus, NE) & Short & & \\
\hline Plant Efficiency Improvements & & U.S. & Electric Power G \& T \\
\hline Transformer Changeout & & U.S. & Electric Power G \& T \\
\hline Distribution Improvements & & U.S. & Electric Power G \& T \\
\hline Hydro Efficiency Improvements & & U.S. & Electric Power G \& $T$ \\
\hline Street Light Conversions & & U.S. & Energy End Use \\
\hline New England Electric System (NEES) Cos. (Westborough, MA) & Long & & \\
\hline Brayton Point Station Unit No. 4 Gas Conversion & & U.S. & Electric Power G \& T \\
\hline Demand-Side Management Programs & & U.S. & Energy End Use \\
\hline Greon Lights Program & & U.S. & Energy End Use \\
\hline Johnston Landfill Gas to Electricity Project & & U.S. & Waste Methane \\
\hline Turnkey Landfill Gas to Electricity Project & & U.S. & Waste Methane \\
\hline Reduced Impact Logging Project & & Foreign & Carbon Sequestration \\
\hline
\end{tabular}




\begin{tabular}{|c|c|c|c|}
\hline Reporter/Project & Form & U.S. or Foreign & Project Type \\
\hline $\begin{array}{l}\text { Appliance Removal Program } \\
\text { Coal Ash Recycling as Cement Replacement }\end{array}$ & & $\begin{array}{l}\text { U.S. } \\
\text { U.S. }\end{array}$ & $\begin{array}{l}\text { Halogenates } \\
\text { Other }\end{array}$ \\
\hline Niagara Mohawk Power Corporation (Syracuse, NY) & Long & & \\
\hline Nuclear Generation Performance Improvements & & U.S. & Electric Power G \& $T$ \\
\hline Amorphous Metal Core Transformers & & U.S. & Electric Power G \& $T$ \\
\hline Installation and Operation of Wind Turbines & & U.S. & Electric Power G \& T \\
\hline Installation and Operation of Photovoltaic Energy Systems & & U.S. & Electric Power G \& $T$ \\
\hline Outdoor Lighting Lamp Conversion Program & & U.S. & Energy End Use \\
\hline Energy Efficiency and Conservation Programs (DSM) - External & & U.S. & Energy End Use \\
\hline Energy Efficiency and Conservation Programs (DSM) - Internal & & U.S. & Energy End Use \\
\hline Alternative Fuel Vehicles & & U.S. & Transportation \\
\hline Identify \& Rehabilitate Leaky Gas Distribution Pipeline & & U.S. & Oil \& Gas Methane \\
\hline Refrigerator Roundup & & U.S. & Halogenates \\
\hline Coal Ash Utilization & & U.S. & Other \\
\hline Investment Recovery Program (Recycling) & & U.S. & Other \\
\hline NIPSCO Industries (Hammond, IN) & Long & & \\
\hline Heat Rate Improvements & & U.S. & Electric Power G \& $T$ \\
\hline Low Loss Transformers & & U.S. & Electric Power G \& $T$ \\
\hline Capacitor Additions & & U.S. & Electric Power G \& $T$ \\
\hline Energy Efficiency- Residential & & U.S. & Energy End Use \\
\hline Energy Efficiency-Commercial & & U.S. & Energy End Use \\
\hline Energy Efficiency- Industrial & & U.S. & Energy End Use \\
\hline Electric Vehicles and Equipment & & U.S. & Transportation \\
\hline Natural Gas Vehicles & & U.S. & Transportation \\
\hline Employee Commute Options & & U.S. & Transportation \\
\hline Landfill Methane Recovery & & U.S. & Waste Methane \\
\hline North Trenton Pipeline Replacement & & U.S. & Oil \& Gas Methane \\
\hline Rural Tree Planting & & U.S. & Carbon Sequestration \\
\hline Urban Treo Planting & & U.S. & Carbon Sequestration \\
\hline Ozone Depleting Chemicals & & U.S. & Halogenates \\
\hline Coal Combustion Byproduct Utilization & & U.S. & Other \\
\hline Recycling program & & U.S. & Other \\
\hline Employee Training & & U.S. & Other \\
\hline Noranda Aluminum Inc. (New Madrid, MO) & Long & & \\
\hline PFC Emission Reductions via Reductions in Anode Effects & & U.S. & Halogenates \\
\hline Northern States Power Company (Minneapolis, MN) & Long & & \\
\hline Wind Power & & U.S. & Electric Power G \& T \\
\hline Nuclear Capacity Increase & & U.S. & Electric Power G \& T \\
\hline Demand Side Management (Electric) & & U.S. & Energy End Use \\
\hline Green Lights & & U.S. & Energy End Use \\
\hline Appliance Recycling & & U.S. & Halogenates \\
\hline Coal ash utilization & & U.S. & Other \\
\hline Northwest Fuel Development, Inc. (Lake Oswego, OR) & Long & & \\
\hline Control and Utilization of Coal Mine Gas & & U.S. & Oil \& Gas Methane \\
\hline Ohio Edison Company (Akron, OH) & Long & & \\
\hline Heat Rate Improvement & & U.S. & Electric Power G \& T \\
\hline Fuel Switching & & U.S. & Electric Power G \& T \\
\hline Efficient Lighting & & U.S. & Energy End Use \\
\hline Efficient Motors & & U.S. & Energy End Use \\
\hline Refrigerator Recycling Program & & U.S. & Energy End Use \\
\hline Tree Source & & U.S. & Carbon Sequestration \\
\hline Refrigerator Recycling & & U.S. & Halogenates \\
\hline Production of Fly Ash for Use as a Substitute for Portland Cement & & U.S. & Other \\
\hline
\end{tabular}




\begin{tabular}{|c|c|c|c|}
\hline Reporter/Project & Form & U.S. or Foreign & Project Type \\
\hline Omaha Public Power District (Omaha, NE) & Short & & \\
\hline Coal Heat Rate Improvement & & U.S. & Electric Power G \& $T$ \\
\hline T\&D Capacitor Installations & & U.S. & Electric Power G \& T \\
\hline Nuclear Capacity Factor Improvement & & U.S. & Electric Power G \& T \\
\hline Heat Pump Program (RECP) & & U.S. & Energy End Use \\
\hline Street Lighting Replacement & & U.S. & Energy End Use \\
\hline Commercial \& Industrial Audits & & U.S. & Energy End Use \\
\hline Right Lights & & U.S. & Energy End Use \\
\hline Treo Planting & & U.S. & Carbon Sequestration \\
\hline Recycling Fly Ash & & U.S. & Other \\
\hline Oregon State University (State of Oregon) (Corvallis, OR) & Long & & \\
\hline RU.S.AFOR-SAP & & Foreign & Carbon Sequestration \\
\hline Osage Municipal Utilities (Osage, IA) & Long & & \\
\hline Overhead Door Replacement at Municipal Complex- Project 1.3 & & U.S. & Electric Power G \& T \\
\hline Central AC Tune Up Rebate Program Project 3.1 & & U.S. & Energy End Use \\
\hline Residential Furnace Tune Up Rebate Program- Project 3.2 & & U.S. & Energy End Use \\
\hline Residential Load Management Program Project $3.3^{\circ}$ & & U.S. & Energy End Use \\
\hline Residential Lo-Flow Shower Heads Project 3.4 & & U.S. & Energy End Use \\
\hline Residential Water Heater Jackets Project 3.5 & & U.S. & Energy End Use \\
\hline Energy Audits Program Project 3.6 & & U.S. & Energy End Use \\
\hline Faucet Aerator Project- Project 3.7 & & U.S. & Energy End Use \\
\hline Compact Fluorescent Lighting Rebate Program-Project 3.8 & & U.S. & Energy End Use \\
\hline Treo-Cooling Effects- Project 3.9 & & U.S. & Energy End Use \\
\hline Tree Planting Program Project 8.1 & & U.S. & Carbon Sequestration \\
\hline Pacific Gas and Electric Co. (San Francisco, CA) & Short & & \\
\hline New 1994 Energy Efficiency & & U.S. & Energy End Use \\
\hline Prior Energy Efficiency in 94 & & U.S. & Energy End Use \\
\hline New 1994 Energy Efficiency & & U.S. & Energy End Use \\
\hline Prior Energy Efficiency in 94 & & U.S. & Energy End Use \\
\hline New 94 NGV & & U.S. & Transportation \\
\hline Prior NGV in 94 & & U.S. & Transportation \\
\hline PacifiCorp (Portland, OR) & Long & & \\
\hline Salt Lake City Urban Forestry Project & & U.S. & Energy End Use \\
\hline Super Good Cents & & U.S. & Energy End Use \\
\hline Manufactured Housing Acquisition Program (MAP) & & U.S. & Energy End Use \\
\hline Low Income Weatherization and Conservation Programs & & U.S. & Energy End Use \\
\hline Residential Weatherization Programs & & U.S. & Energy End Use \\
\hline Home Comfort & & U.S. & Energy End Use \\
\hline Water Heater / Solar & & U.S. & Energy End Use \\
\hline Hassle-Free Program & & U.S. & Energy End Use \\
\hline Showerhead Program & & U.S. & Energy End Use \\
\hline Utah Water Smart Kits (Schedule 5) & & U.S. & Energy End Use \\
\hline Super Efficiency Refrigerator Program (SERP) & & U.S. & Energy End Use \\
\hline H-PRO High Efficiency Heat Pumps & & U.S. & Energy End Use \\
\hline Energy FinAnswer & & U.S. & Energy End Use \\
\hline Energy FinAnswer Prescriptive & & U.S. & Energy End Use \\
\hline Energy FinAnswer Retrofit & & U.S. & Energy End Use \\
\hline Industrial Energy FinAnswer & & U.S. & Energy End Use \\
\hline Major Accounts Program & & U.S. & Energy End Use \\
\hline Irrigation FinAnswer Program & & U.S. & Energy End Use \\
\hline Salt Lake City Urban Forestry Project & & U.S. & Carbon Sequestration \\
\hline Reforestation in Eastern Washington & & U.S. & Carbon Sequestration \\
\hline Reforestation of Private Lands in Oregon-Site Class III & & U.S. & Carbon Sequestration \\
\hline Reforestation of Private Lands in Oregon - Site Class II & & U.S. & Carbon Sequestration \\
\hline
\end{tabular}




\begin{tabular}{|c|c|c|c|}
\hline Reporter/Project & Form & U.S. or Foreign & Project Type \\
\hline Coal Ash Recycling & & U.S. & Other \\
\hline Peabody Holding Company, Inc (St. Louis, MO) & Long & & \\
\hline Coal Bed Methane Utilization & & U.S. & Oil \& Gas Methane \\
\hline Pennsylvania Power \& Light Co (PP\&L) (Allentown, PA) & Long & & \\
\hline SSES Re-Rate & & U.S. & Electric Power $G \& T$ \\
\hline Martins Creek Gas & & U.S. & Electric Power G \& $T$ \\
\hline Heat Rate Reduction & & U.S. & Electric Power G \& $T$ \\
\hline SSES Strategy 2000 & & U.S. & Electric Power G \& $T$ \\
\hline Transformer Savings & & U.S. & Electric Power G \& $T$ \\
\hline Demand Side Management Project & & U.S. & Energy End Use \\
\hline Electric Vehicles & & U.S. & Transportation \\
\hline Trees for the Future & & U.S. & Carbon Sequestration \\
\hline Ash Use in Cement Making & & U.S. & Other \\
\hline Portland General Electric Co. (Portland, OR) & Long & & \\
\hline T\&D: Power Factor Correction Capacitors & & U.S. & Electric Power G \& T \\
\hline Oak Grove Turbine Runner Replacements - 1991 - Units $1 \& 2$ & & U.S. & Electric Power G \& T \\
\hline Sullivan Turbine Rebuilds & & U.S. & Electric Power G \& T \\
\hline Bull Run Turbine Runner Replacements & & U.S. & Electric Power G \& T \\
\hline Faraday Units $4 \& 51994$ & & U.S. & Electric Power G \& T \\
\hline Beaver Efficiency Improvements & & U.S. & Electric Power G \& T \\
\hline Boardman Efficiency Improvements & & U.S. & Electric Power G \& T \\
\hline Demand-Side Management Projects & & U.S. & Energy End Use \\
\hline Natural Gas Fleet Vehicles & & U.S. & Transportation \\
\hline Potomac Electric Power Company (Washington, DC) & Long & & \\
\hline GLP-Lighting Replacement Energy & & U.S. & Energy End Use \\
\hline Mgmt/Conservation Programs & & U.S. & Energy End Use \\
\hline Public Utility District No. 1 of Snohomish County (WA) & Long & & \\
\hline Transmission Networking and Reconductoring & & U.S. & Electric Power G \& T \\
\hline Conservation Voltage Reduction & & U.S. & Electric Power $G \& T$ \\
\hline Demand Side Management & & U.S. & Energy End Use \\
\hline Commute Reduction Program & & U.S. & Transportation \\
\hline Bicycles for Meter Readers & & U.S. & Transportation \\
\hline Battery and Solar Powered Boat Races & & U.S. & Transportation \\
\hline We-cycle Office Wastepaper (WOW) Program & & U.S. & Other \\
\hline Puget Sound Power \& Light Company (Everett, WA) & Long & & \\
\hline Demand Side Management & & U.S. & Energy End Use \\
\hline Salt River Project (Tempe, AZ) & Short & & \\
\hline Heat Rate Improvement & & U.S. & Electric Power $G \& T$ \\
\hline Installed High Efficiency Purge System on Chillers & & U.S. & Halogenates \\
\hline Replaced R-11 with R-123 in 2 Chillers & & U.S. & Halogenates \\
\hline Santee Cooper (Moncks Corner, SC) & Long & & \\
\hline Cross Unit 2 Upgrade & & U.S. & Electric Power G \& T \\
\hline Demand Side Management Programs & & U.S. & Energy End Use \\
\hline Forestation/Reforestation & & U.S. & Carbon Sequestration \\
\hline Fly Ash Used in Cement Manufacture & & U.S. & Other \\
\hline Seattle City Light (Seattle, WA) & Long & & \\
\hline Gorge Dam Turbine Runner Replacement & & U.S. & Electric Power G \& T \\
\hline Diablo Dam Turbine Runner Replacement & & U.S. & Electric Power G \& T \\
\hline Ross Dam Turbine Runner Replacement & & U.S. & Electric Power $\mathrm{G} \& T$ \\
\hline Cedar Falk Turbine Runner Replacement & & U.S. & Electric Power G \& T \\
\hline $4 \mathrm{kV}$ to $26 \mathrm{kV}$ Distribution System Conversion & & U.S. & Electric Power G \& $T$ \\
\hline Home Water Savers Program & & U.S. & Energy End Use \\
\hline Multifamily Common Area Lighting Program (MF-CAL) & & U.S. & Energy End Use \\
\hline Warm Home Program (WMHM) & & U.S. & Energy End Use \\
\hline
\end{tabular}




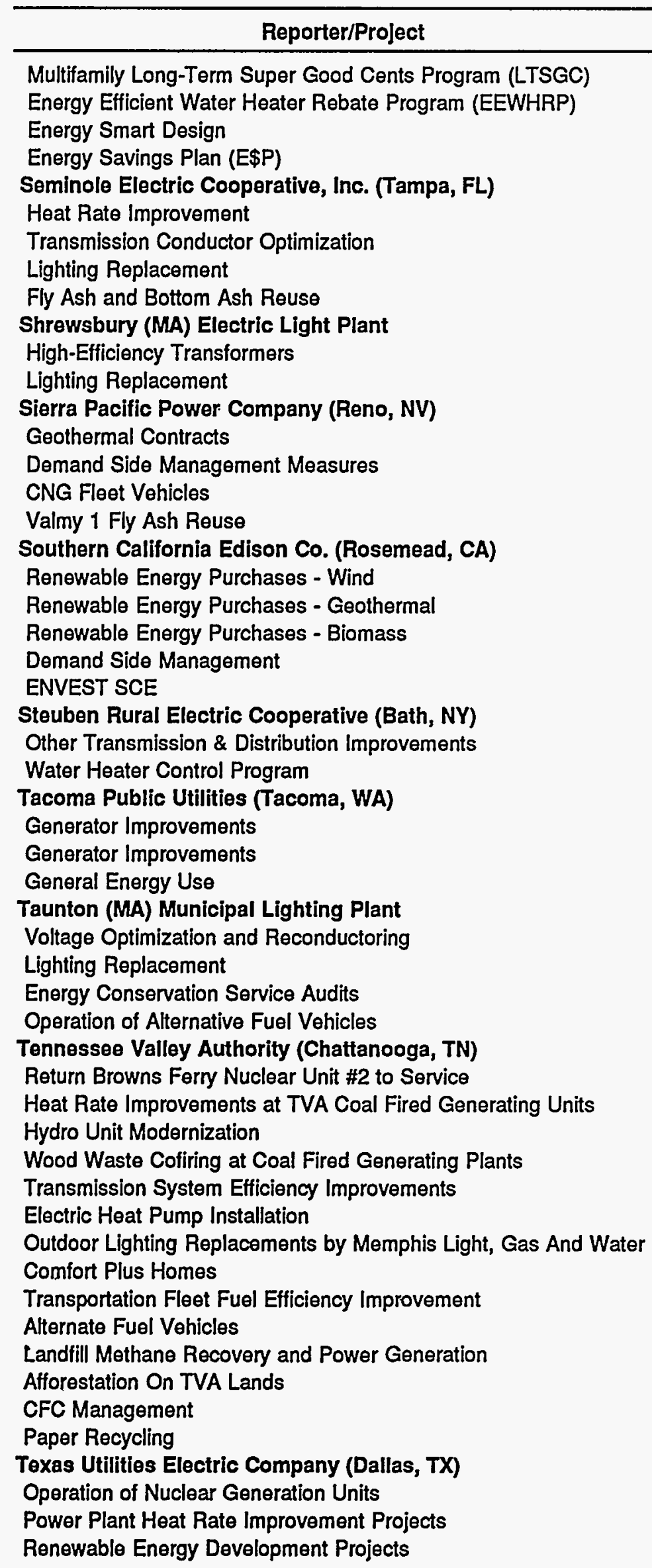

\begin{tabular}{|l|l|l|} 
Form & U.S. or Foreign \\
\hline
\end{tabular}

Project Type

Multifamily Long-Term Super Good Cents Program (LTSGC)

U.S.

U.S.

U.S.

U.S.

Short

U.S. Electric Power $G$ \& $T$

U.S.

U.S.

U.S.

Energy End Use

Energy End Use

Energy End Use

Energy End Use

Short

Long

Long

U.S. Electric Power G \& $T$

U.S. Energy End Use

U.S. Electric Power G \& T

U.S. Energy End Use

U.S. Transportation

U.S. Other

U.S. Electric Power $G \& T$

U.S. Electric Power $G \& T$

U.S. Electric Power $G \& T$

U.S. Energy End Use

U.S. Energy End Use

Short

Short

U.S. Electric Power $\mathrm{G} \& \mathrm{~T}$

U.S. Energy End Use

U.S. Electric Power $G$ \& $T$

U.S. Electric Power $G$ \& $T$

U.S. Energy End Use

Short

U.S. Electric Power G \& T

U.S. Energy End Use

U.S. Energy End Use

U.S. Transportation

Long

U.S. Electric Power $G$ \& $T$

U.S. Electric Power $G \& T$

U.S. Electric Power $G$ \& $T$

U.S. Electric Power $G \& T$

U.S. Electric Power $G$ \& T

U.S. Energy End Use

U.S. Energy End Use

U.S. Energy End Use

U.S. Transportation

U.S. Transportation

U.S. Waste Methane

U.S. Carbon Sequestration

U.S. Halogenates

U.S. Other

Long

U.S. Electric Power G \& $T$

U.S. Electric Power $G \& T$

U.S. Electric Power G \& T 


Form U.S. or Foreign

\section{Project Type}

\begin{tabular}{l} 
Reporter/Project \\
\hline Demand Side Management Program \\
Vehicle Use Reduction \\
Increased Reforestation in Land Reclamation Program \\
Coal Ash Byproduct Use \\
The Detroit Edison Company (Detroit, MI) \\
Increased Nuclear Utilization \\
Greenwood Energy Center Fuel Switching \\
Distribution Improvements \\
Energy Partnerships \\
Electric Vehicle Demonstration Project \\
Landfill Gas Recovery Projects and Energy Purchases \\
The Southern Company (Atlanta, GA) \\
Heat Rate Improvement on Coal-Fired Capacity \\
Biomass \\
Plant Alvin W. Vogtle Capacity Uprate \\
Plant Alvin W. Vogtle Nuclear Availability Improvements \\
Bulk Power Transmission Improvements \\
Chevron Cogenerating Plant - Unit 5 \\
Demand Side Management \\
Transportation Research \\
Carbon Sequestration on Company Lands \\
Trees for the Future (Silver Spring, MD) \\
Guatemala \\
Ghana \\
Cameroon
\end{tabular}

\section{U.S.}

U.S.

U.S.

U.S.

Long

Increased Nuclear Utilization

Greenwood Energy Center Fuel Switching

Distribution Improvements

Energy Partnerships

Electric Vehicle Demonstration Project

Landfill Gas Recovery Projects and Energy Purchases

The Southern Company (Atlanta, GA)

Heat Rate Improvement on Coal-Fired Capacity

Plant Alvin W. Vogtle Capacity Uprate

Plant Alvin W. Vogtle Nuclear Availability Improvements

Demand Side Management

Transportation Research

Carbon Sequestration on Company Lands

Trees for the Future (Silver Spring, MD)

Guatemala

Cameroon

Belize

India

Nepal

Union Electric Company (St. Louis, MO)

Subtransmission Reconductoring

Transformer Replacement

Waste Oil Heat Recovery

Meramec Power Plant Control Upgrade

Conversion to a Dry Fly Ash Handling System

Install Adjustable Speed Fan Drives Replacing Fixed Speed Drives

Replaced Motor-Generator Exciters with Static Exciter System

Projects

Street Light Conversion

Purchase of Light Weight Rail Cars

United Power Association (Elk River, MN)

Ultrasonic and Helium Leak Detection Improvements

Cooling Tower Improvements

Load Management

Ground-Source Heat Pumps

Conservation

Refuse Derived Fuel (RDF) Project

Coal Ash Programs

Geothermal Generation Plant

ervation
U.S.
U.S.
U.S.
U.S.
U.S.
U.S.

Long

U.S. Electric Power $G$ \& $T$

U.S.

U.S.

U.S.

U.S.

U.S.

U.S.

U.S.

U.S.

Long

Foreign

Foreign

Foreign

Foreign

Foreign

Foreign

Foreign

Long

U.S.

U.S.

U.S.

U.S.

U.S.

U.S.

U.S.

U.S.

U.S.

U.S.

U.S.

U.S.

Long

U.S.

U.S.

U.S.

U.S.

U.S.

U.S.

U.S.

U.S.

Short

$\begin{array}{ll}\text { U.S. } & \text { Electric Power G \& T } \\ \text { U.S. } & \text { Energy End Use }\end{array}$ 


\begin{tabular}{|c|c|c|c|}
\hline Reporter/Project & Form & U.S. or Foreign & Project Type \\
\hline $\begin{array}{l}\text { Street Light Replacement Program } \\
\text { Tree Planting }\end{array}$ & & $\begin{array}{l}\text { U.S. } \\
\text { U.S. }\end{array}$ & $\begin{array}{l}\text { Energy End Use } \\
\text { Agriculture }\end{array}$ \\
\hline Utility Board of Key West (FL) & Short & & \\
\hline High-Efficiency Transformers & & U.S. & Electric Power G \& T \\
\hline General Energy Use & & U.S. & Energy End Use \\
\hline Lighting Replacement & & U.S. & Energy End Use \\
\hline Tree Planting & & U.S. & Carbon Sequestration \\
\hline Vermont Public Power Supply Authority (Waterbury Center, VT) & Long & & \\
\hline Swanton Village Hydro Expansion & & U.S. & Electric Power G \& T \\
\hline Transmission and Distribution System Efficiency Improvements & & U.S. & Electric Power G \& T \\
\hline Residential Water Heating and Lighting Efficiency Program & & U.S. & Energy End Use \\
\hline Residential Appliance Disposal Program & & U.S. & Energy End Use \\
\hline Residential Low Income Weatherization Piggyback Program & & U.S. & Energy End Use \\
\hline Residential Mail Order Lighting Program & & U.S. & Energy End Use \\
\hline Farm Efficiency Program & & U.S. & Energy End Use \\
\hline Small Commercial Retrofit Program & & U.S. & Energy End Use \\
\hline Large Commercial and Industrial Audit Program & & U.S. & Energy End Use \\
\hline Equipment Replacement and Remodeling Program & & U.S. & Energy End Use \\
\hline Street and Area Lighting Efficiency Program & & U.S. & Energy End Use \\
\hline Act 250 New Construction Program & & U.S. & Energy End Use \\
\hline Waverly Light \& Power Company (Waverly, IA) & Long & & \\
\hline Wind Turbine (Project 1) & & U.S. & Electric Power G \& T \\
\hline Hydro (Project 2) & & U.S. & Electric Power $G \& T$ \\
\hline Distribution System Upgrade (Project 3) & & U.S. & Electric Power $G$ \& $T$ \\
\hline Low-Loss Transformers (Project 4) & & U.S. & Electric Power $\mathrm{G} \& \mathrm{~T}$ \\
\hline Energy End-Use Programs (Project 3.1) & & U.S. & Energy End Use \\
\hline High Pressure Sodium Lights (Project 3.2) & & U.S. & Energy End Use \\
\hline Energy-Savings Due to Trees Forever (Project 3.3) & & U.S. & Energy End Use \\
\hline Electric Vehicle (Project 4.1) & & U.S. & Transportation \\
\hline Trees Forever (Project 8.1) & & U.S. & Carbon Sequestration \\
\hline Western Resources, Inc. (Topeka, KS) & Long & & \\
\hline JEC2 Turbine Upgrade & & U.S. & Electric Power $G \& \&$ \\
\hline Wolf Creek Increased Capacity Rating & & U.S. & Electric Power $\mathrm{G} \& \mathrm{~T}$ \\
\hline Transformer Replacements & & U.S. & Electric Power G \& T \\
\hline Distribution Capacitor Additions & & U.S. & Electric Power $\mathrm{G} \& \mathrm{~T}$ \\
\hline LEC5 Upgrades & & U.S. & Electric Power $G \& T$ \\
\hline HEC4 Cooling Tower Upgrade & & U.S. & Electric Power $G \& T$ \\
\hline GEV1 Feedwater Heater Upgrade & & U.S. & Electric Power G \& T \\
\hline TEC8 Condenser Upgrade & & U.S. & Electric Power G \& T \\
\hline LAC2 Turbine Upgrade & & U.S. & Electric Power $G \& T$ \\
\hline JEC1 Precipitator Intermittent Energization & & U.S. & Electric Power G \& T \\
\hline JEC2 Precipitator Intermittent Energization & & U.S. & Electric Power $\mathrm{G} \& \mathrm{~T}$ \\
\hline Photovoltaic Installations & & U.S. & Electric Power G \& T \\
\hline Residential Conservation Use Rate DSM Program & & U.S. & Energy End Use \\
\hline Electrotechnologies Marketing & & U.S. & Energy End Use \\
\hline Conversion of Company Fleet Vehicles to Alternative Fuels & & U.S. & Transportation \\
\hline Natural Gas Distribution System Replacement Program & & U.S. & Oil \& Gas Methane \\
\hline Natural Gas Transmission System Blowdown Reductions & & U.S. & Oil \& Gas Methane \\
\hline Wisconsin Electric Power Co. (Milwaukee, WI) & Long & & \\
\hline Fossil Plant Heat Rate Improvements & & U.S. & Electric Power G \& T \\
\hline Hydro Plant Improvement and Additions & & U.S. & Electric Power G \& $\mathrm{T}$ \\
\hline Transmission \& Distribution System Loss Reductions & & U.S. & Electric Power G \& T \\
\hline Demand Side Management Energy Efficiency Programs & & U.S. & Energy End Use \\
\hline Vehicle Conversion to Dual Fuel Capability & & U.S. & Transportation \\
\hline
\end{tabular}




\begin{tabular}{|c|c|c|c|}
\hline Reporter/Project & Form & U.S. or Foreign & Project Type \\
\hline Beneficial Use of Landfill Methane & & U.S. & Waste Methane \\
\hline CFC-12 Recovery from Appliance Turn-In Program & & U.S. & Halogenates \\
\hline Fly Ash Substitution Program & & U.S. & Other \\
\hline Wisconsin Power \& Light (Madison, WI) & Long & & \\
\hline 111 Heat Rate Improvement & & U.S. & Electric Power G \& T \\
\hline 370 Fuel Switching & & U.S. & Electric Power $G \& T$ \\
\hline 111- Efficiency Improvements & & U.S. & Electric Power $G \& T$ \\
\hline 111 Efficiency Improvements & & U.S. & Electric Power G \& T \\
\hline 111 Efficiency Improvements & & U.S. & Electric Power $G \& T$ \\
\hline 111 Efficiency Improvements & & U.S. & Electric Power $G \& T$ \\
\hline Tire Derived Fuel Generation & & U.S. & Electric Power $\mathrm{G} \& \mathrm{~T}$ \\
\hline Energy End Use Projects - Electric & & U.S. & Electric Power G \& T \\
\hline Energy End Use - Gas & & U.S. & Energy End Use \\
\hline 822 Modified Forest Management & & U.S. & Carbon Sequestration \\
\hline 851- Conservation Tillage & & U.S. & Carbon Sequestration \\
\hline 821 Forest Preservation & & U.S. & Carbon Sequestration \\
\hline 811 Afforestation & & U.S. & Carbon Sequestration \\
\hline Habitat Restoration & & U.S. & Carbon Sequestration \\
\hline Wisconsin Public Power, Inc. (Sun Prairie, WI) & Long & & \\
\hline Boswell Heat Rate Reduction & & U.S. & Electric Power G \& T \\
\hline Kaukauna CT 18 I\&C Upgrade & & U.S. & Electric Power G \& T \\
\hline Fuel Switching New Generation & & U.S. & Electric Power $G \& T$ \\
\hline Dispatch Change Menasha Units & & U.S. & Electric Power G \& T \\
\hline Switching Electric to Gas & & U.S. & Energy End Use \\
\hline Residential Appliances & & U.S. & Energy End Use \\
\hline Commercial/industrial & & U.S. & Energy End Use \\
\hline Compact Fluorescent & & U.S. & Energy End Use \\
\hline Street Lighting & & U.S. & Energy End Use \\
\hline Tree Power (1991 Planting) 4 Yr Olds & & U.S. & Carbon Sequestration \\
\hline Tree Power (1992 Planting) 3 Yr Olds & & U.S. & Carbon Sequestration \\
\hline Tree Power (1993 Planting) 2 Yr Olds & & U.S. & Carbon Sequestration \\
\hline Tree Power (1994 Planting) 1 Yr Olds & & U.S. & Carbon Sequestration \\
\hline Wisconsin Public Service Corporation (Green Bay, WI) & Shoit & & \\
\hline Transmission Line Construction & & U.S. & Electric Power G \& T \\
\hline Demand Side Management programs & & U.S. & Energy End Use \\
\hline Afforestation and Reforestation Efforts & & U.S. & Carbon Sequestration \\
\hline Zahren Alternative Power Corp. (Avon, CT) & Short & & \\
\hline Landfill Gas Recovery for Energy, Oceanside & & U.S. & Waste Methane \\
\hline Landfill Gas Recovery for Energy, SPSA & & U.S. & Waste Methane \\
\hline Landfill Gas Recovery for Energy, Smithtown & & U.S. & Waste Methane \\
\hline Landfill Gas Recovery for Energy, Oyster Bay & & U.S. & Waste Methane \\
\hline Landfill Gas Recovery for Energy, Hamm's & & U.S. & Waste Methane \\
\hline Landfill Gas Recovery for Energy, Bondi's & & U.S. & Waste Methane \\
\hline Landfill Gas Recovery for Energy, Intervale & & U.S. & Waste Methane \\
\hline Landfill Gas Recovery for Energy, Amity Facility & & U.S. & Waste Methane \\
\hline Landfill Gas Recovery for Energy, Onondaga & & U.S. & Waste Methane \\
\hline Landfill Gas Recovery for Energy, Dunbarton & & U.S. & Waste Methane \\
\hline Zeeland Board of Public Works (Zeeland, MI) & Short & & \\
\hline Other Transmission \& Distribution improvements & & U.S. & Electric Power G \& T \\
\hline Other Transmission \& Distribution Improvements & & U.S. & Electric Power G \& T \\
\hline Tree Planting & & U.S. & Carbon Sequestration \\
\hline
\end{tabular}

Source: Energy Information Administration, Forms EIA-1605 and EIA-1605EZ, "Voluntary Reporting of Greenhouse Gases" (1995 reporting cycle). 


\section{Glossary}

Afforestation: Planting of new forests on lands that have not been recently forested.

Anaerobic lagoon: A liquid-based manure management system, characterized by waste residing in water to a depth of at least 6 feet for a period ranging between 30 and 200 days.

Associated gas: Natural gas found mixed with crude oil in underground reservoirs, released as a byproduct of oil production.

Baseline period: The years 1987 through 1990 for which entity-level emissions may be reported.

Biofuels: Organic materials, such as wood, waste, and alcohol, burned for energy purposes.

Biogas: A mixture of carbon dioxide and methane produced through bacterial action.

Biomass: Materials that are biological in origin, including organic material (both living and dead) from above and below ground, e.g., trees, crops, grasses, tree litter, roots, and animals and animal waste.

British thermal unit (Btu): A common unit used in measuring energy, equal to the amount of heat needed to raise the temperature of 1 pound of water by $1^{\circ} \mathrm{F}$.

Carbon sink: A reservoir that absorbs or takes up released carbon. Vegetation and soils are common carbon sinks.

Chlorofluorocarbons (CFCs): A family of inert, nontoxic, and easily liquefied chemicals used in refrigeration, air conditioning, packaging, and insulation, or as solvents or aerosol propellants. Because they are nonreactive, they drift into the upper atmosphere, where they are disassociated by solar radiation and where their components destroy ozone.

Cogeneration: The sequential use of energy to generate electricity and another form of useful thermal energy, such as heat or steam.

Commercial-scale: Application of a demonstrated technology at a cost-effective scale.
Commitment: An expressed intention to undertake an action or actions that will reduce greenhouse gas emissions, increase carbon sequestration, or achieve a stated emissions goal.

Conversion factor: $A$ unique value used to convert one unit (e.g., acres) to another appropriate unit (e.g., hectares).

Deforestation: The removal of forest stands.

Emission coefficient/factor: A unique value for scaling emissions to activity data in terms of a standard rate of emissions per unit of activity (e.g., pounds of carbon dioxide emissions per barrel of fossil fuel consumed).

Emissions: Anthropogenic (human-caused) releases of greenhouse gases to the atmosphere (e.g., the release of carbon dioxide during fuel combustion).

Emissions, direct: Emissions from sources owned (wholly or in part) or leased by an entity.

Emissions, fugitive: Emissions that are released inadvertently or accidentally from a controlled or closed system, such as natural gas pipelines.

Emissions, indirect: Emissions from sources not owned or leased by an entity that occur, wholly or in part, as a result of its activities.

Emissions reduction: A decrease in annual greenhouse gas emissions.

Energy conservation: Activities that reduce end-use demand for energy by reducing the service demanded.

Entity: For the purposes of the Voluntary Reporting Program, an individual or organization that is a legal U.S. person (e.g., a U.S. citizen, resident alien, company, organization or group incorporated under or recognized by U.S. law; or a Federal, State, or local government agency).

Entity boundary: Conceptually, a line drawn to encompass the emissions sources and sinks to be evaluated in an entity-level report. An entity boundary should include all the emissions sources and sinks owned 
(wholly or in part) or leased by the entity, and, to the extent possible, other emissions sources and sinks affected by the entity's activities.

Entity-level reporting: The reporting of greenhouse gas emissions, emission reductions, and carbon sequestration for an entire entity.

Estimation method: The techniques, including key assumptions and data sources, used by the reporter to derive the reported emissions, emission reductions, or sequestration.

Foreign activities: All actions outside of the United States, its territories, and trusts.

Fossil fuel: A hydrocarbon fuel, such as petroleum, derived from living matter of a previous geologic time.

Fuel cycle: The entire set of sequential processes or stages involved in the utilization of fuel, including extraction, transformation, transportation, and combustion. Emissions generally occur at each stage of the fuel cycle.

Fuel switching: The substitution of one type of fuel for another. The fuel substitution may be either temporary (as in the case of a power plant that temporarily switches from coal to natural gas) or permanent (as in the case of a fleet operator who replaces gasolinepowered automobiles with electric cars).

Fugitive emissions: See Emissions, fugitive.

Gob: A zone of rubble created when the roof of a coal mine collapses behind the mining operations.

Greenhouse effect: A popular term used to describe the roles of water vapor, carbon dioxide, and other trace gases in keeping the Earth's surface warmer than it would otherwise be. These radiatively active gases are relatively transparent to incoming shortwave radiation but are relatively opaque to outgoing longwave radiation. The latter radiation, which would otherwise escape to space, is trapped by these gases within the lower levels of the atmosphere. The subsequent reradiation of some of the energy back to the Earth maintains surface temperatures higher than they would be if the gases were absent. There is concern that increasing concentrations of greenhouse gases, including carbon dioxide, methane, and man-made halogenated substances, may enhance the greenhouse effect and cause global climate change.

Greenhouse gases: Those gases, such as water vapor, carbon dioxide, tropospheric ozone, nitrous oxide, and methane that are transparent to solar radiation but opaque to long-wave radiation, thus preventing longwave radiation energy from leaving the atmosphere. The greenhouse gases covered by the Voluntary Reporting Program are (1) carbon dioxide $\left(\mathrm{CO}_{2}\right),(2)$ methane $\left(\mathrm{CH}_{4}\right),(3)$ nitrous oxide $\left(\mathrm{N}_{2} \mathrm{O}\right)$, and (4) halogenated substances. Increasing levels of greenhouse gases in the atmosphere may contribute to an increase in average global temperatures, resulting in adverse climate changes.

Halogenated substance: A volatile compound containing halogens, such as chlorine, fluorine, or bromine.

Horizon year: The year in which a commitment to reduce greenhouse gas emissions or increase sequestration (reported on Schedule IV) is expected to be met.

Intergovernmental Panel on Climate Change (IPCC): A panel established jointly in 1988 by the World Meteorological Organization and the United Nations Environment Program to assess scientific information relating to climate change and to formulate realistic response strategies.

Life cycle: A progression of a product through its service life. For most products, emissions and energyconsuming characteristics will be altered as they age.

Longwall mining: A technique of underground mining in which a cutting machine is pulled back and forth along a panel of coal 300 to 1,000 feet wide and as much as 2 miles long. As the panel is cut, the broken coal is removed by a conveyor, and movable roof supports advance, allowing the roof in mined-out areas to collapse.

Manure management: The method used to dispose of the solid waste produced by livestock and poultry.

Municipal solid waste: Residential solid waste and some nonhazardous commercial, institutional, and industrial wastes.

Ozone: A molecule made up of three atoms of oxygen. In the stratosphere, it occurs naturally and provides a protective layer shielding the Earth from harmful ultraviolet radiation. In the troposphere, it is a chemical oxidant and major component of photochemical smog.

Photosynthesis: The manufacture of carbohydrates by plants from carbon dioxide and water in the presence of chlorophyll, with sunlight as the energy source. In this process, carbon is sequestered and oxygen is released.

Pilot project: A small-scale trial designed to test or demonstrate the efficiency or efficacy of a project. 
Project: An action undertaken to reduce greenhouse gas emissions or sequester carbon.

Project boundary: Conceptually, a line drawn to encompass the emissions sources and sinks affected by a project. A project boundary should include all the significant and quantifiable effects of the project.

Project ID code: A unique code assigned by the Energy Information Administration to a reported project for tracking purposes.

Project-level reporting: Reporting on emissions reductions or carbon sequestration achieved as a result of a specific action or group of actions.

Reconductoring: Replacement of existing conductors with large-diameter conductors to reduce line losses. Conductors (including feeders and transmission lines) are a major source of transmission and distribution system losses. In general, the smaller the diameter of the conductor, the greater its resistance to the flow of electric current, and the greater the consequent line losses.

Reference case: The emissions level to which the current actual emissions levels is compared when calculating emissions reductions.

Reference case, basic: A reference case using actual historical emissions or sequestration values.

Reference case, modified: A reference case using projected emissions or sequestration values, representing the emissions level that would have occurred in the absence of the reduction or sequestration efforts.
Reforestation: Replanting of forests on lands that have recently been harvested.

Reporter: An entity (see definition above) completing either Form ELA-1605 or Form EIA-1605EZ and submitting it to the Energy Information Administration.

Room and pillar mining: The most common method of underground coal mining, in which the mine roof is supported by coal pillars left at regular intervals.

Sequestered carbon: Carbon that is removed from the atmosphere and retained in a carbon sink (such as a growing tree) or in soil.

Sequestration: The fixation of atmospheric carbon dioxide in a carbon sink through biological or physical processes, such as photosynthesis.

Sink: See carbon sink.

Third-party reporter: An authorized party that submits a report on behalf of two or more entities which have engaged in emissions-reducing or sequestration-increasing activities. Possible third-party reporters include trade associations reporting on behalf of members that have undertaken reduction projects.

Vhar metering: Phase shifters on watthour meters that measure reactive volt ampere hours or varhours.

Watt (W): A common metric unit used in measuring power (the rate at which work is done), defined as 1 Joule per second and equivalent to 3.412 Btu per hour. 


P

